\title{
Evaluation of Decommissioning Alternatives for the Pilot Plant Complex, Aberdeen Proving Ground
}

\author{
FFR 21900 \\ OSTI
}

Energy Systems Division Argonne National Laboratory

Operated by The University of Chicago, under Contract W-31-109-Eng-38, for the

United States Department of Energy

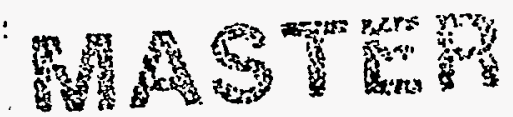




\section{Argonne National Laboratory}

Argonne National Laboratory, with facilities in the states of Illinois and Idaho, is owned by the United States Government, and operated by the University of Chicago under the provisions of a contract with the Department of Energy.

This technical memo is a product of Argonne's Energy Systems (ES) Division. For information on the division's scientific and engineering activities, contact:

Director, Energy Systems Division

Argonne National Laboratory

Argonne, llinois 60439-4815

Telephone (708) 252-3724

Presented in this technical memo are preliminary results of ongoing work or work that is more limited in scope and depth than that described in formal reports issued by the ES Division.

Publishing support services were provided by Argonne's Information and Publishing Division (for more information, see IPD's home page: http://www.ipd.anl.gov/).

\section{Disclaimer}

This report was prepared as an account of work sponsored by an agency of the United States Government. Neither the United States Government nor any agency thereof, nor any of their employees, makes any warranty, express or implied, or assumes any legal liability or responsibility for the accuracy, completeness, or usefulness of any information, apparatus, product, or process disclosed, or represents that its use would not infringe privately owned rights. Reference herein to any specific commercial product, process, or service by trade name, trademark, manufacturer, or otherwise, does not necessarily constitute or imply its endorsement, recommendation, or favoring by the United States Government or any agency thereof. The views and opinions of authors expressed herein do not necessarily state or reflect those of the United States Government or any agency thereof.

Available to DOE and DOE contractors from the Office of Scientific and Technical Information, P.O. Box 62, Oak Ridge, TN 37831; prices available from (423) 576-8401.

Available to the public from the National Technical Information Service, U.S. Department of Commerce, 5285 Port Royal Road, Springtield, VA 22161. 


\section{Evaluation of Decommissioning Alternatives for the Pilot Plant Complex, Aberdeen Proving Ground}

\section{J. Rueda and R.E. Zimmerman}

Center for Environmental Restoration Systems, Energy Systems Division,

Argonne National Laboratory, 9700 South Cass Avenue, Argonne, lllinois 60439

\section{September 1995}

Work sponsored by United States Department of Defense, United States Army, Aberdeen Proving Ground, Maryland

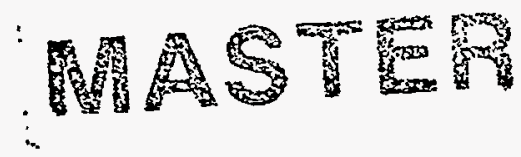


This report is printed on recycled paper. 


\section{Contents}

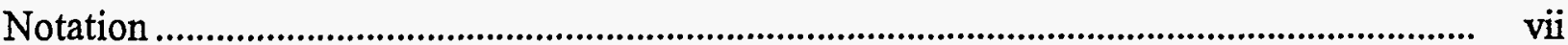

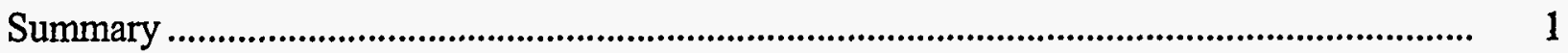

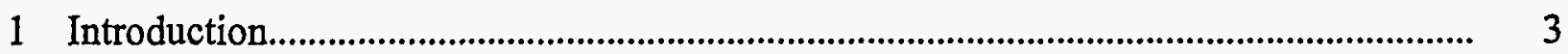

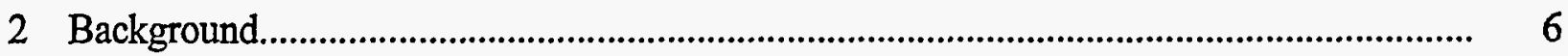

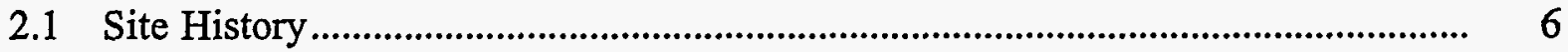

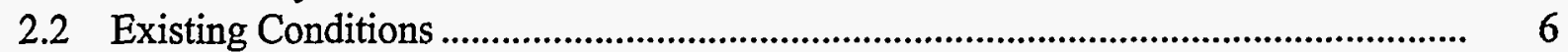

2.2.1 Documentation and Quantification Reports .............................................. 6

2.2.2 Geophysical Surveys ............................................................................... 7

2.2.3 Warfare Chemicals Contamination.......................................................... 7

2.2.4 Levels of Volatile Organic Compounds and Polychlorinated Biphenyls....... 7

2.2.5 Lead Loading ........................................................................................ 8

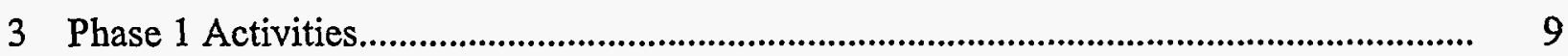

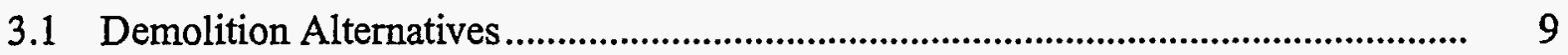

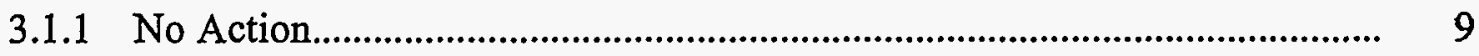

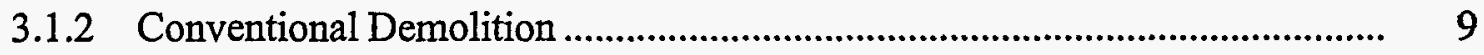

3.1.3 Controlled Demolition............................................................................... 11

3.1.4 Enclosed Demolition ........................................................................... 13

3.2 Debris Testing Program................................................................................ 14

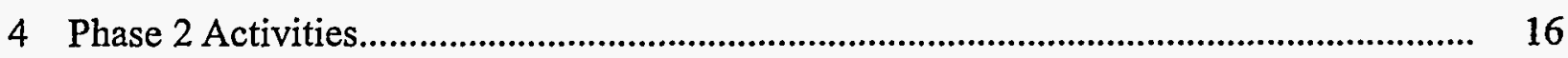

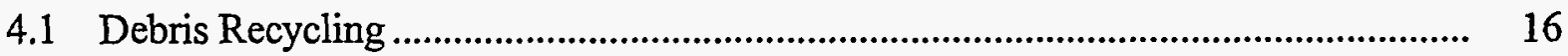

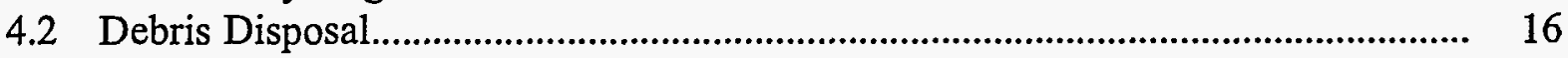

4.2.1 On-Site Landfill ................................................................................... 16

4.2.2 Commercial Nonhazardous Waste Landfill ............................................ 16

4.2.3 Hazardous Waste Landfill ................................................................... 17

4.3 Waste Treatment........................................................................................... 17

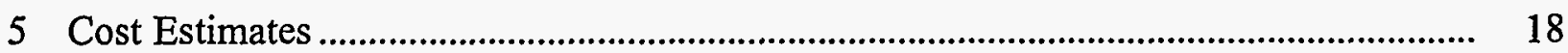

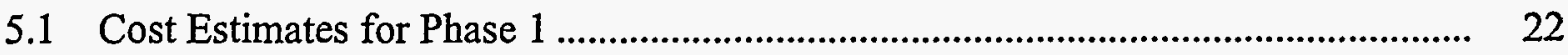

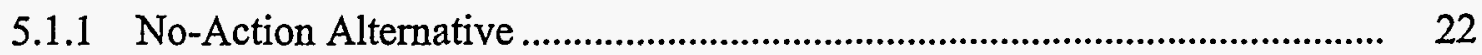

5.1.2 Conventional Demolition Alternative ....................................................... 22

5.1.3 Controlled Demolition Alternative.......................................................... 27

5.1.4 Enclosed Demolition Alternative .............................................................. 33

5.2 Cost Estimates for Phase 2 .......................................................................... 38

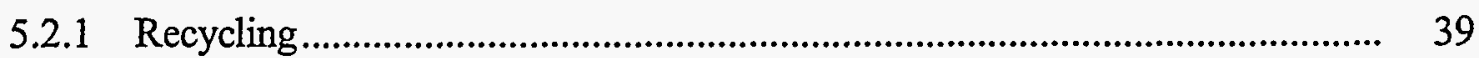

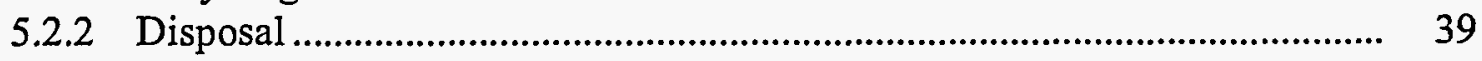




\section{Contents (Cont.)}

5.2.2.1 On-Site Landfill............................................................................. 39

5.2.2.2 Commercial Nonhazardous Waste Landfill..................................... 39

5.2.2.3 Hazardous Waste Landfill ................................................................ 41

5.2.3 Waste Treatment....................................................................................... 41

5.3 Unit Cost and Quantity Estimates........................................................................... 41

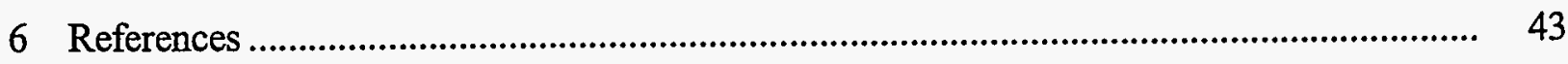

Appendix: Quantity Estimates for the Pilot Plant Complex ................................................ 45

\section{Tables}

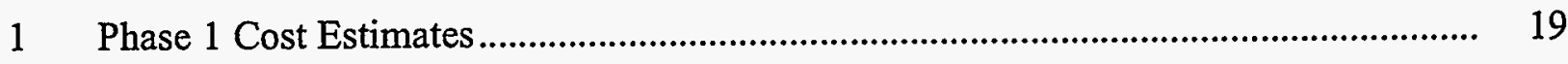

$2 \quad$ Phase 2 Cost Estimates............................................................................................... 20

3 Combined Cost Estimates for Phases 1 and 2 ......................................................... 21

$4 \quad$ Cost Estimates for Phase 1 No-Action Alternative .......................................................... 23

5 Cost Estimates for Phase 1 Conventional Demolition Alternative.................................. 24

6 Cost Estimates for Phase 1 Controlled Demolition Alternative ....................................... 28

$7 \quad$ Cost Estimates for Phase 1 Enclosed Demolition Alternative......................................... 34

8 Cost Estimates for Recycling, Disposal, and Treatment ................................................. 40

9 Unit Costs.............................................................................................................. 42

A.1 Pilot Plant Complex Structural Survey Summary ........................................................ 51

A.2 Pilot Plant Complex Material Weight Summary ............................................................ 51

A.3 Building E5616 Structural Survey Summary................................................................. 52

A.4 Building E5617 Structural Survey Summary.................................................................. 52

A.5 Building E5618 Structural Survey Summary................................................................ 53

A.6 Building E5621 Structural Survey Summary ................................................................. 53

A.7 Building E5625 Structural Survey Summary ............................................................... 54 


\section{Tables (Cont.)}

A.8 Building E5626 Structural Survey Summary................................................................ 54

A.9 Building E5627 Structural Survey Summary .................................................................. 55

A.10 Building E5632 Structural Survey Summary................................................................... 55

A.11 Building E5633 Structural Survey Summary................................................................ 56

A.12 Pilot Plant Grounds Structural Survey Summary ........................................................... 56

Figures

1 Map Showing the Location of Aberdeen Proving Ground.................................................. 4

$2 \quad$ Layout of the Pilot Plant Complex …………………....................................................... 5

A.1 Aberdeen Proving Ground Location Map.......................................................................... 48

A.2 Layout of the Pilot Plant Complex ………....................................................................... 49

A.3 Building E5616 Floor Plan .................................................................................... 57

A.4 Building E5617 Floor Plan ................................................................................. 58

A.5 Building E5618 Floor Plan .................................................................................... 59

A.6 Building E5621 Floor Plan ........................................................................................ 60

A.7 Building E5625 First Floor Plan............................................................................... 61

A.8 Building E5625 Second Floor Plan ......................................................................... 62

A.9 Building E5625 Third Floor Plan ............................................................................. 63

A.10 Building E5625 Fourth Floor Plan .......................................................................... 64

A.11 Building E5625 Fifth Floor Plan ................................................................................ 65

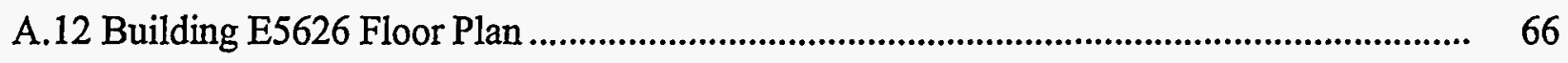

A.13 Building E5627 Floor Plan ..................................................................................... 67 
Figures (Cont.)

A.14 Building E5632 Floor Plan ..................................................................................... 68

A.15 Building E5633 Floor Plan ......................................................................................... 69 


\section{Notation}

\section{Acronyms and Initialisms}

$\begin{array}{ll}\text { ANL } & \text { Argonne National Laboratory } \\ \text { APG } & \text { Aberdeen Proving Ground } \\ \text { CC2, GA, GB, GD, } & \\ \text { H, L, and VX } & \text { various chemical warfare agents } \\ \text { DDESBA } & \text { U.S. Department of Defense Explosion Safety Board } \\ \text { O \& M } & \text { operations and maintenance } \\ \text { OSHA } & \text { U.S. Occupational Health and Safety Administration } \\ \text { PCB } & \text { polychlorinated biphenyl } \\ \text { PPC } & \text { Pilot Plant Complex } \\ \text { TCLP } & \text { toxic characterization leaching procedure } \\ \text { VOC } & \text { volatile organic compound } \\ \text { X, XXX, and } & \text { designations of contamination level for objects subjected to } \\ \text { XXXXX } & \text { exposure to liquid or vapor chemical agent }\end{array}$

\section{Units of Measure in Text}

$\begin{array}{ll}{ }^{\circ} \text { Celsius } & \text { degrees Celsius } \\ { }^{\circ} \text { Fahrenheit } & \text { degrees Fahrenheit } \\ \mathrm{cfm} & \text { cubic feet per minute } \\ \mathrm{cm}^{2} & \text { square centimeter(s) } \\ \mathrm{ft} & \text { foot (feet) } \\ \text { in. } & \text { inch(es) } \\ \mathrm{m}^{3} & \text { cubic meter(s) } \\ \mu \mathrm{g} & \text { microgram(s) } \\ \mathrm{mg} & \text { milligram(s) }\end{array}$

\section{Units of Measure in Tables}

$\begin{array}{ll}\text { ACRE } & \text { acre(s) } \\ \text { CF } & \text { cubic foot (feet) } \\ \text { CFM } & \text { cubic feet per minute } \\ \text { CY } & \text { cubic yard(s) } \\ \text { EA } & \text { each } \\ \text { HR } & \text { hour(s) } \\ \text { LF } & \text { linear foot (feet) } \\ \text { LS } & \text { lump sum } \\ \text { MI } & \text { mile(s) } \\ \text { RT } & \text { round trip } \\ \text { SF } & \text { square foot (feet) } \\ \text { TON } & \text { ton(s) }\end{array}$




\title{
Evaluation of Decommissioning Alternatives for the Pilot Plant Complex, Aberdeen Proving Ground
}

\author{
by
}

\author{
J. Rueda and R.E. Zimmerman
}

\section{Summary}

This report presents an evaluation of four decommissioning alternatives for the Pilot Plant Complex (PPC), an inactive chemical weapons research, development, and production facility consisting of nine buildings located in the Edgewood Area of the Aberdeen Proving Ground in Maryland.

Decommissioning the PPC involves six steps: (1) assessing existing conditions; (2) dismantling the aboveground portions of the buildings (including the floor slabs, paved roads, and sidewalks within the PPC); (3) reducing the size of the demolition debris and sealing the debris in containers for later testing and evaluation; (4) testing and evaluating the debris; (5) conducting site operation and maintenance activities; and (6) recycling or disposing of the debris with or without prior treatment, as appropriate.

Documentation of step 1, the assessment of existing conditions at the PPC, can be found in separate reports prepared by Argonne National Laboratory. This report is concerned with steps 2 through 6, which have been grouped into two decommissioning phases. Phase 1 involves building dismantling, debris testing, and subsequent site operation and maintenance. Phase 2 relates to the recycling, disposal, and possible treatment of the debris.

Four Phase 1 dismantling alternatives were considered: no action, conventional demolition, controlled demolition, and enclosed demolition. The estimated cost to implement Phase 1 activities ranges from $\$ 410,000$ to more than $\$ 51$ million, depending on the alternative. The estimated cost to implement Phase 2 activities ranges from a material cost offset of $\$ 150,000$, if all of the debris is recycled without any treatment, to more than $\$ 31$ million, if all of the debris is treated and disposed of at a hazardous waste landfill site. Therefore, the estimated cost to implement both Phases 1 and 2 ranges from $\$ 410,000$ to more than $\$ 82$ million. 


\section{Introduction}

This report presents an evaluation of four decommissioning alternatives for the nine buildings of the Pilot Plant Complex (PPC), an inactive chemical weapons research, development, and production facility, at Aberdeen Proving Ground (APG). The APG is located on Maryland's Chesapeake Bay in Harford and Baltimore Counties (see Figure 1) and is divided into the Edgewood and Aberdeen Areas. The PPC is in the Edgewood Area. A site plan of the PPC is shown in Figure 2.

Decommissioning the PPC involves six steps: (1) assessing the condition of the existing buildings; (2) dismantling the aboveground portions of the buildings, including the floor slabs, paved roads, and sidewalks within the PPC (building footings, foundation piers, sumps, underground utilities, and other below-ground structures or facilities are to be left in place and filled with concrete, as appropriate); (3) reducing the size of the demolition debris and sealing it in containers for later testing and evaluation; (4) testing and evaluating the debris; (5) conducting site operation and maintenance activities; and (6) recycling or disposing of the debris with or without prior treatment, as appropriate.

The initial decommissioning activities, the documentation and assessment of existing conditions at the PPC, were undertaken as part of the overall Argonne National Laboratory (ANL) effort (Brubaker et al. 1994). These activities include documentation and quantification of the nine PPC buildings (Draugelis et al. 1995a,b; Smits et al. 1995; O'Reilly et al. 1995a,b; Muir-Ploense et al. 1995; Miller et al. 1995; Zellmer et al. 1995a,b); an environmental geophysical assessment (McGinnis et al. 1994); air monitoring for volatile organic compounds (Schneider et al. 1995a); testing known locations for glycolates and arsenic (Tomczyk et al. 1995); and additional testing for polychlorinated biphenyls (PCBs) (Schneider et al. 1995b), lead on painted walls (Brubaker et al. 1995a), and heavy metals on metal surfaces (Brubaker et al. 1995b). The cost of these assessments has been assigned to a separate program and, therefore, does not contribute to the cost estimates contained here.

This report is concerned with steps 2 through 6 , which have been grouped into two decommissioning phases. Decommissioning activities 2 through 5 were considered to be Phase 1 activities, while step 6 activities were relegated to Phase 2. Four Phase 1 dismantling alternatives were considered: no action, conventional demolition, controlled demolition, and enclosed demolition. 


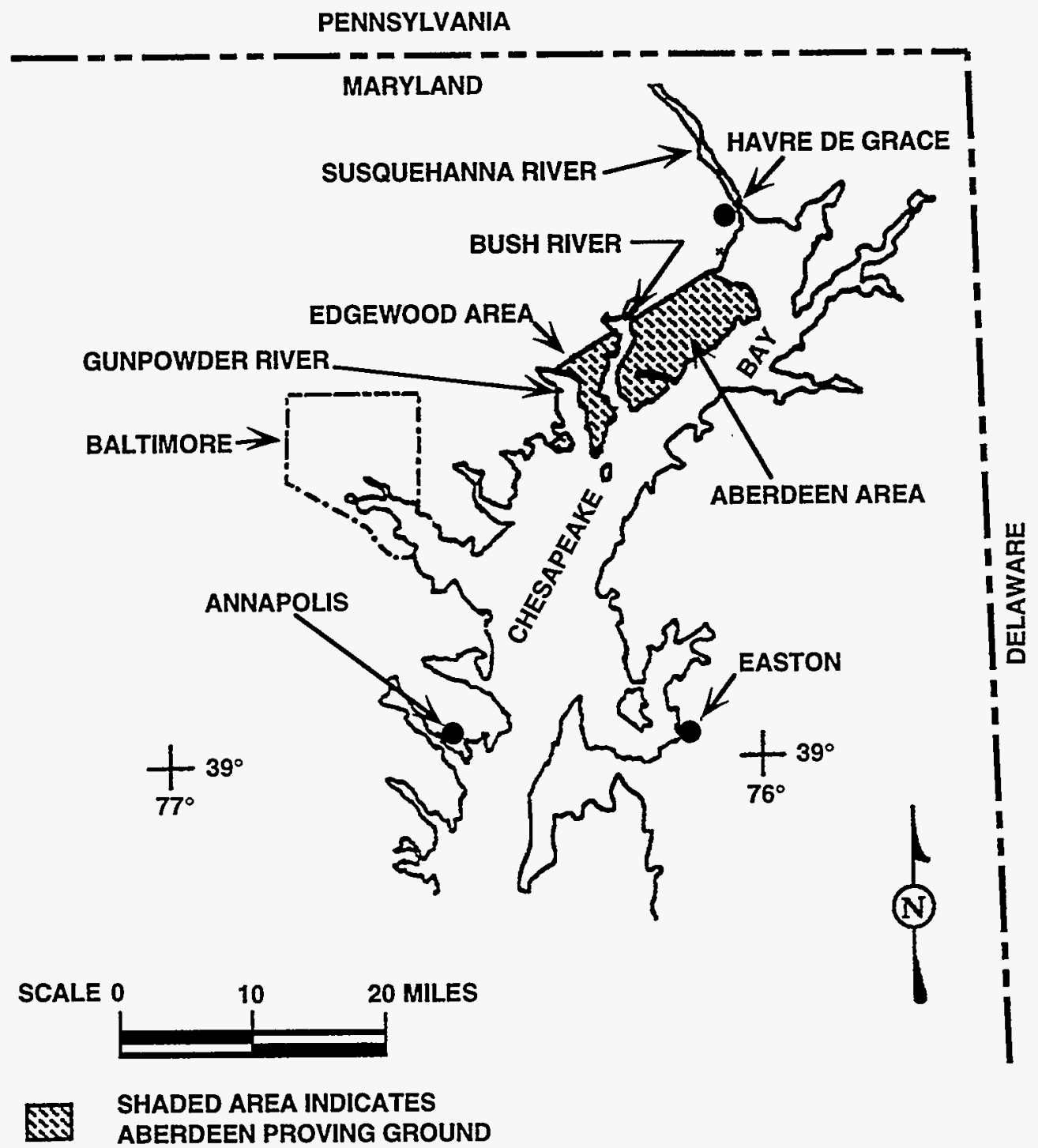

FIGURE 1 Map Showing the Location of Aberdeen Proving Ground 


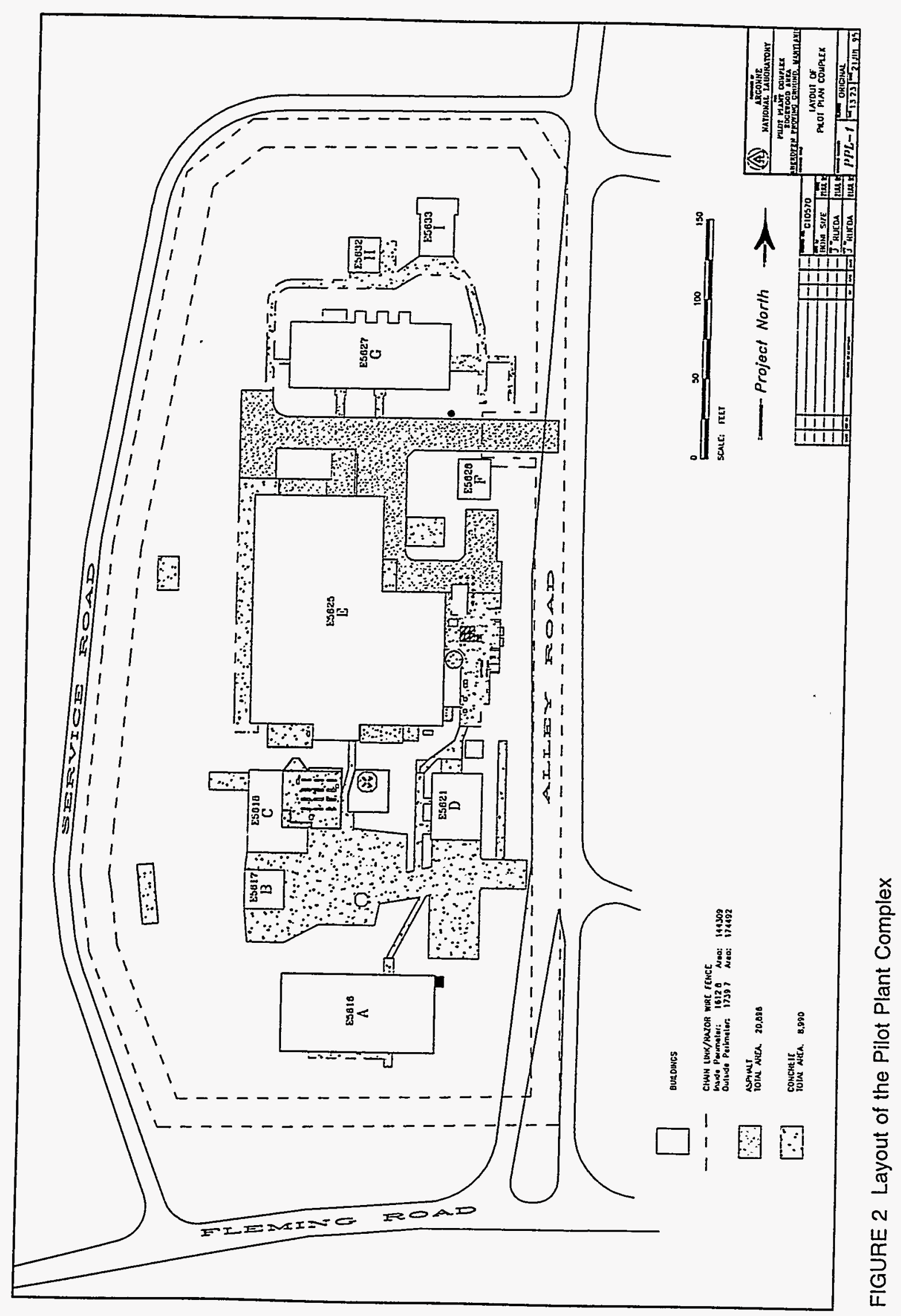




\section{Background}

\subsection{Site History}

Most of the PPC buildings were constructed in 1941 for the manufacture of $\mathrm{CC} 2$, an impregnite material (Anderson et al. 1995) that was incorporated into military clothing to provide protection against chemical agents, primarily mustard (Yon 1988). The PPC was used for that purpose from January through December 1942 (Nemeth 1989). In early 1943, Building E5625 was converted to a pilot plant for studies into an alternative method for producing impregnite. After World War II, Building E5625 was converted to a general-purpose laboratory and pilot plant (Yon 1988). From that time through the mid-1980s, the PPC was used for the research, development, testing, and small-scale production of military chemicals. The PPC went out of s̀ervice in March 1986 and has not been used since. By mid-1993, the buildings had been stripped of production and office equipment, piping, instruments and controls, and most of the metal sheeting that had been on the floors and walls of the labs. Only a few light fixtures, metal floors and walls, unsalvageable plumbing fixtures, and some installed electric wiring remain in the buildings.

\subsection{Existing Conditions}

\subsubsection{Documentation and Quantification Reports}

The documentation and assessment of existing conditions at the PPC were undertaken as part of the overall ANL effort (Brubaker et al. 1994). These activities include documentation and quantification of the nine PPC buildings (Draugelis et al. 1995a,b; Smits et al. 1995; O'Reilly et al. 1995a,b; Muir-Ploense et al. 1995; Miller et al. 1995; Zellmer et al. 1995a,b); an environmental geophysical assessment (McGinnis et al. 1994); air monitoring for volatile organic compounds (Schneider et al. 1995a); testing known locations for glycolates and arsenic (Tomczyk et al. 1995); and additional testing for PCBs (Schneider et al. 1995b), lead on painted walls (Brubaker et al. 1995a), and heavy metals on metal surfaces (Brubaker et al. 1995b).

Detailed maps of the site and drawings of the PPC buildings were developed on the basis of field measurements and available APG drawings. These maps and drawings were used during the field assessment and testing programs conducted by ANL and will provide documentation for future efforts. The Documentation and Quantification Report for each PPC building includes a historical record-search summary; descriptions of every room on every floor; existing floor plans; photographic documentation of wall, floor, and ceiling surfaces; a geophysical subsurface investigation summary; and a structural definition that includes detailed in-situ material estimates. Floor plans and summaries of the existing materials for the nine PPC buildings are presented in the Appendix. 


\subsubsection{Geophysical Surveys}

A geophysical survey was conducted (McGinnis et al. 1994) in the immediate vicinity of each PPC building by using several nonintrusive techniques, including total-field magnetics, electric conductivity, time-domain electrical induction, and ground-penetrating radar. The geophysical survey was conducted to assist in locating and identifying pipes, tanks, trenches, and liquid waste in the subsurface. Multiple databases have been integrated to provide support for detection of underground utilities, stratigraphy, and lithology.

\subsubsection{Warfare Chemicals Contamination}

Because most of the PPC buildings were used for the research, development, testing, or pilot-scale production of chemical warfare agents and other military substances (such as incendiary materials or munitions containing these materials), the buildings were evaluated for contamination by such materials, their degradation products, and other laboratory or industrial chemicals.

The contamination level of any object that has been subjected to exposure to chemicalagent liquid or vapor contamination is designated as either $\mathrm{X}, \mathrm{XXX}$, or XXXXX, as described in Department of the Army PAM 385-61 (Roman 1995). The X designation indicates that the level of contamination is either unknown or that the object is contaminated with at least one compound that exceeds the following criteria: $0.003 \mathrm{mg} / \mathrm{m}^{3}$ for mustard or Lewisite agents, $0.0001 \mathrm{mg} / \mathrm{m}^{3}$ for nerve agent GA/GB, $0.00001 \mathrm{mg} / \mathrm{m}^{3}$ for nerve agent $\mathrm{VX}$, or $0.00003 \mathrm{mg} / \mathrm{m}^{3}$ for nerve agent GD. The XXX designation indicates that the object has been decontaminated at its surface and that air monitoring has verified that vapor concentrations are not greater than $0.003 \mathrm{mg} / \mathrm{m}^{3}$ for mustard agents, $0.0001 \mathrm{mg} / \mathrm{m}^{3}$ for nerve agent GA/GB, and $0.00001 \mathrm{mg} / \mathrm{m}^{3}$ for nerve agent VX. The XXXXX designation indicates that the object is clean and may be released from government control without agent-related precautions or restrictions. The XXXXX designation could also be assigned to any material that has been subjected to a temperature of $538^{\circ}$ Celsius $\left(1000^{\circ}\right.$ Fahrenheit) for a minimum of 15 minutes. Testing is not required when the heat treatment is applied.

All of the buildings except Building E5626 were classified XXX in 1992 and 1993 and each is so marked at its entrance; Building E5626 has been classified as XXXXX (Roman 1995).

\subsubsection{Levels of Volatile Organic Compounds and Polychlorinated Biphenyls}

An air monitoring study (Schneider et al. 1995a) was conducted by ANL in the fall of 1994 to screen the air inside each building and identify any potential sources of volatile organic compounds (VOCs). More than 180 air samples were evaluated by ANL support laboratories, and no hazardous chemical contaminants were found at levels of concern. 
The air monitoring study also included a testing program for PCBs (Schneider et al. 1995b). On the basis of the air-sampling results, wipe samples were taken in areas suspected of having PCB contamination. PCB concentrations in the air samples from inside the buildings were found to be well below accepted levels; the total PCB burden for the PPC appears to be well below the 5 parts per million level. However, analytical results from the wipe samples taken from Rooms 03 and 04 in Building E5618 exceeded $1000 \mu \mathrm{g} / 100 \mathrm{~cm}^{2}$. Also, Building E5625 has several oil-stained areas where PCB-wipe-sample concentrations exceeded $100 \mu \mathrm{g} / 100 \mathrm{~cm}^{2}$.

\subsubsection{Lead Loading}

Lead loading on painted walls was also evaluated by ANL (Brubaker et al. 1995a). Approximately 1,000 $\mathrm{x}$-ray fluorescence measurements for lead loading on painted wall surfaces were taken in the PPC buildings in December 1994. Preliminary results indicate that the amount of lead present in the examined buildings is far too low to present any regulatory waste disposal problems. 


\section{Phase 1 Activities}

\subsection{Demolition Alternatives}

This section describes the four alternative approaches that were reviewed for the demolition of the aboveground structures in the PPC. These alternatives are no action, conventional demolition, controlled demolition, and enclosed demolition. The aboveground PPC structures will be razed, including the floor slabs. However, the foundations and other belowgrade structures (such as sumps or utility systems) will be left in place. The PPC structures were evaluated by ANL for the possible presence of airborne VOCs, PCBs, lead on painted walls, and heavy metals (lead, chromium, and cadmium) on painted structural steel, as described in Section 2.2.

\subsubsection{No Action}

The no-action alternative will allow the buildings to age naturally, as no attempt will be made to dismantle them. The PPC site will then not be used for any other activity. The no-action alternative will include repairing one of the existing double, 8 - $\mathrm{ft}$ chain-link fences as needed and possibly adding another fence and/or a security system. Only grass mowing will be permitted inside the fenced area at the PPC.

\subsubsection{Conventional Demolition}

The conventional demolition alternative will include dismantling the PPC facilities by using state-of-practice, open-air conventional demolition techniques. Implementation of this alternative assumes that the PPC buildings are below levels of concern for contaminating agents or any other listed hazardous or toxic materials. Therefore, personnel involved with the field dismantling activities will not be required to use any personal protective clothing or equipment for chemical agents or other listed hazardous or toxic materials.

Site preparation activities for this alternative will include construction of barriers, required access roads for demolition equipment, construction of temporary runoff controls, and the mobilization of field offices and demolition equipment.

The PPC structures will be collapsed in their entirety by using one or a combination of such conventional demolition techniques as the wrecking ball, impact rams, breakers, diamondtipped cutting tools, flame- or water-cutting tools, jaw crushers, or explosives. Selection of the preferred conventional demolition technique will be left to the contractor. The demolished debris will be reduced in size by either cutting in place or crushing, as needed for recycling as a fill or riprap material or for disposal as construction demolition debris. A dust monitoring program will 
be conducted to verify that air-quality standards for particulate matter are not exceeded during the conventional demolition activities.

Once the demolition activities are completed and the debris is removed, the PPC site will be regraded as needed to give it a positive drainage. The site will then be covered with a lowpermeability soil material that will be revegetated to prevent soil erosion. Operation and maintenance activities will include grass mowing, inspections for soil erosion, and repair of damaged areas, as needed.

Commonly used conventional demolition techniques for noncontaminated buildings are described below (Carpenter et al. 1988):

- Wrecking Ball. A heavy wrecking ball suspended from a crane smashes against the structures, eventually knocking them down to ground level. The wrecking ball method is probably the most common and most cost-effective way to demolish medium-size buildings, because of the low manpower requirements and the short time required to perform the operation. Potentially large quantities of dust may be generated when this method is used.

- Impact Rams. Impact rams are used to break concrete and other brittle materials. The impact ram method is labor-intensive and generates a large amount of dust. Impact rams provide sufficient control to selectively remove structural members (such as specific walls or floors). An advantage to using an impact ram with a backhoe is that structures below and above ground level can be broken up and excavated.

- Breakers. Breakers are hydraulically activated cylinders used to split brittle materials. In general, shins are used to cut steel and jaws are used to cut concrete. Breakers can be used to remove structures containing reinforced bars. One disadvantage of breakers is that their use is labor-intensive, especially since holes must be initially drilled.

- Diamond-Tipped Cutting Tools. Diamond-tipped cutting tools can cut or drill through concrete, brick, and reinforcing bars. The amount of dust generated is minimized because the dust becomes trapped in the cooling water to form a slurry. Cutting concrete this way eliminates the shock and vibration associated with impact rams.

- Flame Cutting. Flame cutting is a high-velocity, high-temperature cutting process using oxygen, powdered aluminum, and powdered iron for fuel. Flame-cutting equipment can be set up for remote operation when cutting in critical areas. Flame cutting is economical and practical for the removal of 
extremely thick and heavily reinforced sections of concrete; however, it is not economical for relatively thin walls because of the high cost involved.

- Water-Jet Cutting. Water-jet cutting uses a very high pressure liquid jet to erode the material being cut. The jet medium can be water, a water-polymer solution, or a water-abrasive mixture. Since liquid is used as the cutting medium, a minimum amount of dust is generated. However, the used cutting medium has to be disposed of properly.

- Jaw Crushing. Jaw crushers are high-powered hydraulically or mechanically activated cutters used to cut reinforced concrete or steel. Jaw crushing is laborintensive, and a moderate amount of dust may be produced.

- Explosives. Explosives generate sufficient force to either implode an entire building or selectively remove structural members. When imploding a building, the explosives break up the internal structures and the resulting unsupported weight of the upper floors then collapses the building. Debris from an imploded building must be broken into smaller pieces for handling, which may not be a trivial task in the case of reinforced concrete. Large quantities of dust are possibly generated when this method is used.

\subsubsection{Controlled Demolition}

The controlled demolition alternative will include dismantling each PPC building on a floor-by-floor basis through the use of conventional demolition techniques within a controlled environment. The conventional demolition techniques to be used will be selected according to the working environment.

Implementing the controlled demolition alternative assumes that personnel working within the controlled environment may be exposed to dust generated during the operations. Accordingly, each person involved with the field dismantling activities may be required to use U.S. Occupational Safety and Health Administration (OSHA) Level B personal protective clothing and equipment, including a Tyvex suit with hood, a safety hat, a self-contained breathing apparatus or supplied air, a full-face respirator, chemical-resistant boots having steel toes and shanks, and gloves.

Site preparation activities will include the construction of barriers and environmental controls, implementation of emergency-response procedures during the dismantling operations, construction of required access roads for demolition equipment, construction of temporary runoff and silt controls, and mobilization of field offices and demolition equipment. 
Environmental controls will include erecting exterior-enclosure envelopes on a floor-byfloor basis, as well as establishing negative air-pressure and dust-control systems. The exteriorenclosure envelopes will seal the exterior openings with polyethylene sheeting or a similar material to minimize the uncontrolled escape of dust particles into the atmosphere. If necessary, windows in the exterior walls and openings in the floors and ceilings will be boarded up to maintain the integrity of the enclosure envelope. The potential release of contamination and dust will be further minimized by removing almost all of the interior structures before removing the exterior structures. The negative air-pressure system will pull air into the enclosure through air leakage holes in the enclosure envelope and then exhaust it into the atmosphere. Prior to its release, the exhausted air will pass through suitable particulate and activated-carbon filters. The negative air-pressure and dust-control systems will be designed to handle four air-volume changes per hour. Agent detection devices will be installed upstream and downstream of the air filter system and will activate audible and visible alarms. Planned emergency-response actions will be initiated when an alarm occurs. Personnel decontamination stations will be used to prevent personnel and equipment from carrying contaminants outside the envelope enclosures.

The controlled demolition of each PPC building will begin by disassembling the interior walls and then proceed to the disassembly of the exterior walls. The walls in Building E5625 will be disassembled on a floor-by-floor basis, beginning with the upper floor. Disassembly of the building's structural steel and floor slabs will follow, once the walls have been removed. Structural considerations may dictate that the first disassembly step involves the removal of the building's roof. When this is the case, a temporary roof will be installed in its place. Interior and exterior walls will typically be removed on a panel-by-panel basis, as applicable. A wall panel is generally defined as any building material located between two adjacent building structural steel columns on a given floor. A typical wall panel in the PPC buildings is $20 \mathrm{ft}$ long by $13 \mathrm{ft}$ high.

Continuous real-time air monitoring and testing will be conducted inside each enveloped area being dismantled. Once the interior walls are removed, the exterior walls will be removed only after the results of the continuous, real-time air monitoring and testing are acceptable for level XXX contamination. If air monitoring and testing show results that are unacceptable for level XXX contamination, a surface decontamination procedure acceptable for a level $\mathrm{XXX}$ designation will be conducted and followed by level XXX certification testing.

The debris generated from the demolition of the internal and external walls will be transferred from each working area to size-reduction equipment by means of enclosed transfer chutes, conveyors, or closed boxes. The containment area and the enclosed transfer chutes or conveyors will be connected to an air/dust control system. The size-reduced debris will be sealed inside 10- to 20-cubic-yard containers. A representative sample of the debris will be collected as each container is filled. These samples will be analyzed for classification purposes as part of the debris testing program described in Section 3.2. The exterior of the debris containers will be washed down with water in the air-lock area. Each batch of debris will be tracked from its origin, through the sizer, and to its container.

When the interior and exterior walls have been removed, the remaining structure will consist of reinforced concrete floors and the structural steel that forms the building's skeleton. 
These elements will be air tested for level XXX contamination and treated accordingly, if necessary. The standing structures will then be dropped to the ground by pulling, mechanical cutting, or blasting the support columns after the envelope enclosures have been removed. The floor slabs will be broken up, size-reduced, and placed in debris containers for evaluation.

After the dismantling activities are completed and the dismantling equipment is removed, the PPC site will be regraded to have positive drainage. Then the site will be covered by a lowpermeability material that is overlaid with topsoil, which will be revegetated to prevent soil erosion.

Operation and maintenance activities will include grass mowing, periodic inspections, and repair of damaged surfaces, as needed.

\subsubsection{Enclosed Demolition}

The enclosed-demolition alternative will include dismantling the PPC buildings by using conventional demolition techniques under a totally enclosed environment on a building-bybuilding basis whereby each PPC building is treated separately. Conventional demolition techniques will be selected according to the working environment and the building materials.

Implementing the enclosed-demolition alternative assumes that personnel working within the enclosed environment may be exposed to dust generated during the operations. Accordingly, each person involved with the field dismantling activities will be required to use OSHA Level B personal protective clothing and equipment, including a Tyvex suit with hood, a safety hat, a self-contained breathing apparatus or supplied air, a full-face respirator, chemical-resistant boots having steel toes and shanks, and gloves.

Site preparation activities will include the construction of barriers and environmental controls, implementation of emergency-response procedures during the dismantling operations, construction of required access roads for demolition equipment, construction of temporary runoff and silt controls, and the mobilization of field offices and demolition equipment.

Environmental controls will include erecting exterior enclosures on a building-by-building basis, as well as establishing negative air-pressure and dust-control systems. The enclosures will be constructed of fabric material capable of protecting the PPC site from the environment. Because of the negative air-pressure system, a frame will be required to support the envelope fabric material. This frame will be designed to prevent the envelope fabric material from sagging between frame members in a way that can trap rain or snow. The frame will also be designed to have a clear span so as not to inhibit the demolition operation. The enclosures will most likely be custom-designed and will be used only for this project. 
The negative air-pressure system will pull air into the enclosure through the air-supply holes of the enclosure envelope and then exhaust it into the atmosphere. The exhausted air will pass through particulate and activated-charcoal filters prior to its release. The negative airpressure and dust-control systems will be designed to handle four air-volume changes per hour. Agent detection devices will be installed upstream and downstream of the air filter system and will activate audible and visible alarms. Planned emergency-response actions will be initiated if an alarm occurs. Personnel decontamination stations will be used to eliminate the possibility of personnel and equipment carrying potential contaminants outside the enclosures.

The debris generated from the demolition operation will be transferred from each floor to the size-reduction equipment by enclosed transfer chutes, conveyors, or closed boxes, as applicable. The enclosed transfer chutes or conveyors will be connected to the negative airpressure system to minimize the release of potential contamination to the outside atmosphere. The crushed debris will then be sealed in 10- to 20-cubic-yard containers. A representative sample of the debris will be collected as each container is filled. These samples will be analyzed for classification purposes as part of the debris testing program described in Section 3.2. The exterior of each sealed debris container will be washed down with water in the air-lock area. Each batch of debris will be tracked from its origin, through the sizer, and to each debris container.

The enclosure envelope for each PPC building will be removed for disposal at a commercial landfill once the demolition debris from the building has been completely removed.

After the dismantling activities have been completed - including removal of the dismantling equipment, negative air-pressure and dust-control systems, barriers, and security fences - the PPC site will be regraded to give it a positive drainage. It will then receive a lowpermeability cover that is overlaid with topsoil and revegetated to prevent soil erosion.

Operation and maintenance activities will include grass mowing, periodic inspections, and repair of damaged surfaces, as needed.

\subsection{Debris Testing Program}

A debris testing program will be developed and implemented to evaluate the sized debris for chemical-agent and hazardous-material content. Material samples will be obtained as the debris containers are being filled after the crushing operation.

One alternative method for developing an equivalent XXXXX classification for solid wastes that are potentially contaminated by chemical agents is to monitor the waste headspace vapor concentration for GA, GB, GD, or VX. The allowable headspace vapor concentration cannot exceed $0.000003 \mathrm{mg} / \mathrm{m}^{3}$ (Department of the Army Draft Safety Pamphlet 385-61, entitled, Toxic Chemical Agent Safety Standards). No vapor-phase concentration value is currently available for an equivalent XXXXX classification for mustard $(\mathrm{H})$ or Lewisite $(\mathrm{L})$. The 
specific procedures by which such waste samples are contained for sampling, the sampling procedures used, and the analytical methods employed to generate the headspace concentration levels will be submitted for approval to the Department of Defense Explosion Safety Board (DDESB) prior to implementation. 


\section{Phase 2 Activities}

This section describes Phase 2 activities, which will consist of recycling or disposal of stored demolition debris after treatment, if applicable.

Demolition debris that is determined through testing to be nonhazardous for both chemical agents and other potential hazardous substances will be either recycled or disposed of as ordinary demolition debris. Demolition debris that has been tested and meets the XXXXX level for chemical agents but that contains unacceptable concentrations of other hazardous substances will be disposed of as a hazardous material. Demolition debris showing unacceptable concentrations for both chemical agents and hazardous substances will be treated to bring the chemical-agent content to acceptable levels and then will be disposed of as a hazardous material. Demolition debris found to contain acceptable levels of both chemical agents and hazardous wastes after being treated for unacceptably high chemical-agent levels will be either recycled or disposed of at a demolition debris landfill.

\subsection{Debris Recycling}

Demolition debris that is classified as XXXXX after testing and found to consist of nonhazardous materials will be recycled. Structural steel will be recycled through the existing APG steel-recycling program or through another government facility.

\subsection{Debris Disposal}

Nonrecyclable demolition debris will be disposed of through landfilling, as applicable.

\subsubsection{On-Site Landfill}

Nonrecyclable demolition debris that is shown by testing to consist of either nonhazardous materials or materials that are classified as XXXXX may be landfilled on-site.

\subsubsection{Commercial Nonhazardous Waste Landfill}

Nonrecyclable demolition debris that is classified as XXXXX and is shown by testing to consist of non-hazardous materials may be shipped off-site to a commercial nonhazardous waste landfill, such as a municipal solid waste landfill or a construction demolition landfill. 


\subsubsection{Hazardous Waste Landfill}

Nonrecyclable demolition debris that is shown by testing to contain hazardous materials or those that are classified as XXX will be disposed of as a hazardous material without any additional treatment at a federally controlled hazardous waste disposal site. Because of the XXX classification, restrictions may be imposed throughout the handling, shipping, and disposal process.

\subsection{Waste Treatment}

Thermal decontamination is an approved treatment for decontaminating solid materials to the XXXXX level under existing Department of the Army regulations (Army Regulation 385-61 and PAM 385-61). All of the buildings at the PPC except Building E5626 (the guard and security building) were classified as XXX in 1992 and 1993, while Building E5626 was classified XXXXX (Roman 1995). Because of the large number of agents and chemicals handled at the PPC, thermal treatment is currently the only Department of the Army agent-decontamination procedure that allows unrestricted release or recycling of any $\mathrm{X}$ or XXX classified materials.

Thermal treating can be accomplished by heating the demolition debris to a minimum of $538^{\circ}$ Celsius $\left(1000^{\circ}\right.$ Fahrenheit) and maintaining it at that temperature for a minimum of 15 minutes. The thermal treating of demolition debris, excluding recyclable structural steel, could be conducted in a closed-loop device under a nitrogen atmosphere. The gases and vapors released during heating could be condensed, collected, analyzed, and disposed of according to their hazard classification.

The Decontamination/Detoxification (Decon/Detox) Facility, which is permitted to treat XXX-certified material, will be used to treat the recyclable structural steel from the demolition operation. The Decon/Detox Facility is operated by the Edgewood Research, Development, and Engineering Center (ERDEC) at the Edgewood Area of APG. 


\section{Cost Estimates}

This section provides estimates of the costs involved in developing and implementing the Phase 1 and Phase 2 decommissioning activities. Phase 1 activities will include the dismantling of the aboveground portions of the PPC buildings and implementation of a testing program whereby the demolition debris stored in sealed containers will be classified according to its chemical-agent and hazardous-material content. Operation and maintenance activities will be conducted at the restored PPC site for up to 30 years. Phase 2 activities, which will be implemented after the results of the debris testing program have been evaluated, will include the recycling or disposal of the debris after treatment, if appropriate.

Table 1 specifies the various estimated costs involved in implementing Phase 1 activities for each of the four dismantling alternatives described in Section 3.1. The total estimated cost, which ranges from $\$ 410,000$ to more than $\$ 51$ million, includes the cost of the decommissioning design and site activities, 30 years of operation and maintenance, and a contingency estimate of $15 \%$. The cost of developing and implementing the debris testing program is included as one of the site activities. A detailed description of the Phase 1 cost estimates is presented in Section 5.1.

Table 2 specifies the various estimated costs involved in implementing Phase 2 activities, which include costs for recycling, disposal, and possible treatment of the stored demolition debris, plus a contingency estimate of $15 \%$. The Phase 2 cost estimates are presented in terms of various potential scenarios for each of the proposed dismantling alternatives, since the debris quantities that will be available for recycling, disposal, and treatment are unknown at this time. Five recycling/disposal/treatment scenarios were developed for each of three demolition alternatives. Each scenario shown in Table 2 assumes a different percentage allocation for the debris material that could be available for recycling/disposal/treatment. The cost allocation for each scenario was calculated by multiplying the recycling/disposal/treatment percentages by the cost of each respective activity and then applying that figure to the total amount of available demolition debris. The no-action dismantling alternative has only one Phase 2 scenario, since no material will be available for recycling, disposal, or treatment upon completion of the associated Phase 1 activities. The total estimated cost for the Phase 2 activities ranges from a material cost offset of $\$ 150,000$, if all of the debris is recycled without any treatment, to more than $\$ 31$ million, if all of the debris is treated and disposed of at a hazardous waste site. A detailed description of the Phase 2 cost estimates is presented in Section 5.2.

Table 3 combines the estimated costs of implementing both Phases 1 and 2. This total cost ranges from $\$ 410,000$ to more than $\$ 82$ million.

The following sections detail the cost estimates involved in developing and implementing each of the actions presented. The cost estimates are presented in a tabular format that includes task and subtask nomenclature, a description of the activity, quantity requirements, units of measurement, unit costs, and the total cost rounded to the nearest thousand dollars. The 
TABLE 1 Phase 1 Cost Estimates

\begin{tabular}{|c|c|c|c|c|c|}
\hline $\begin{array}{l}\text { DISMANTUING } \\
\text { ALTERNATIVE }\end{array}$ & $\begin{array}{l}\text { DESIGN } \\
(\$ 1,000)\end{array}$ & $\begin{array}{c}\text { SITE } \\
\text { ACTIVTIES } \\
(\$ 1,000)\end{array}$ & $\begin{array}{c}\text { OPERATION } \\
\text { AND } \\
\text { MAINTENANCE } \\
(\$ 1,000)\end{array}$ & $\begin{array}{l}\text { CONTINGENCY } \\
15 \text { PERCENT } \\
(\$ 1,000)\end{array}$ & $\begin{array}{c}\text { TOTAL } \\
\text { ESTIMATED } \\
\text { COST } \\
(\$ 1,000)\end{array}$ \\
\hline 1- NOACTION & $\$ 20$ & $\$ 67$ & $\$ 270$ & $\$ 53$ & $\$ 410$ \\
\hline $\begin{array}{l}\text { 2- CONVENTIONAL } \\
\text { DEMOUTION }\end{array}$ & $\$ 100$ & $\$ 2,142$ & $\$ 420$ & $\$ 399$ & $\$ 3,061$ \\
\hline $\begin{array}{l}\text { 3- CONTROUED } \\
\text { DEMOUTION }\end{array}$ & $\$ 475$ & $\$ 30,777$ & $\$ 420$ & $\$ 4,751$ & $\$ 36,422$ \\
\hline $\begin{array}{l}\text { 4- ENCLOSED } \\
\text { DEMOLTION } \\
\text { (Envelope) }\end{array}$ & $\$ 616$ & $\$ 43,332$ & $\$ 420$ & $\$ 6,655$ & $\$ 51,024$ \\
\hline
\end{tabular}

\begin{tabular}{|c|c|}
\hline \multicolumn{2}{|c|}{ Dismant ling Alt e rnat ives Descript ion } \\
\hline 1 & No dismanting action will take place. An additional third outer fence will be constructed. \\
\hline 2 & $\begin{array}{c}\text { Dismantling of the PPC facilities using state-of-practice open air demolition activities. Debris to be } \\
\text { stored in sealed containers and tested prior to commence Phase } 2 \text { activities. }\end{array}$ \\
\hline 3 & $\begin{array}{c}\text { Dismantling activities on an enclosed floor-by-floor basis. Debris to be stored in sealed containers } \\
\text { and tested prior to commence Phase } 2 \text { activities. }\end{array}$ \\
\hline 4 & $\begin{array}{c}\text { Dismantling activities on an enveloped building-by-building basis. Debris to be stored in sealed } \\
\text { containers and tested prior to commence Phase } 2 \text { activities. }\end{array}$ \\
\hline
\end{tabular}


TABLE 2 Phase 2 Cost Estimates

\begin{tabular}{|c|c|c|c|c|c|c|c|c|c|c|c|}
\hline \multirow{3}{*}{$\begin{array}{l}\text { DISMANTUING } \\
\text { ALTERNATIVE }\end{array}$} & \multirow{3}{*}{ SCENARIO } & \multirow{2}{*}{\multicolumn{2}{|c|}{ RECYONG }} & \multicolumn{4}{|c|}{ MATERIAL DISPOSITION (100\%) } & \multirow{2}{*}{\multicolumn{2}{|c|}{$\begin{array}{l}\text { TREATMENT } \\
\text { (THERMAL) }\end{array}$}} & \multirow{3}{*}{$\begin{array}{l}\text { CONTINGENCY } \\
15 \text { PERCENT } \\
(\$ 1,000)\end{array}$} & \multirow{3}{*}{$\begin{array}{c}\text { TOTAL } \\
\text { ESTIMATED } \\
\text { COST } \\
(\$ 1,000)\end{array}$} \\
\hline & & & & \multicolumn{2}{|c|}{$\begin{array}{l}\text { DEMOLTION } \\
\text { DEBRIS }\end{array}$} & \multicolumn{2}{|c|}{$\begin{array}{l}\text { HAZARDOUS } \\
\text { WASTE }\end{array}$} & & & & \\
\hline & & $\%$ & $\begin{array}{l}\text { OFFSET } \\
(\$ 1,000)\end{array}$ & $\%$ & $\begin{array}{c}\text { COST } \\
(S 1,000)\end{array}$ & $\%$ & $\begin{array}{c}\text { COST } \\
(\$ 1,000)\end{array}$ & $\%$ & $\begin{array}{c}\text { COST } \\
(\$ 1,000)\end{array}$ & & \\
\hline 1-NOACTION & $1-A$ & 0 & \$o & 0 & \$0 & 0 & $\$ 0$ & 0 & $\$ 0$ & $\$ 0$ & so \\
\hline \multirow{5}{*}{$\begin{array}{l}\text { 2- CONVENTIONAL } \\
\text { DENOITION }\end{array}$} & $2-A$ & 100 & (\$150) & 0 & $\$ 0$ & 0 & \$o & 0 & $\$ 0$ & $\$ 0$ & (\$150) \\
\hline & $2 \cdot B$ & 75 & $(\$ 113)$ & 25 & $\$ 230$ & 0 & $\$ 0$ & 0 & $\$ 0$ & $\$ 35$ & $\$ 152$ \\
\hline & $2-C$ & 50 & (\$75) & 50 & $\$ 461$ & 0 & $\$ 0$ & 0 & $\$ 0$ & $\$ 69$ & $\$ 455$ \\
\hline & 2-D & 25 & (\$38) & 75 & $\$ 691$ & 0 & $\$ 0$ & 0 & $\$ 0$ & $\$ 104$ & $\$ 757$ \\
\hline & 2.E & 0 & \$o & 100 & $\$ 922$ & 0 & $\$ 0$ & 0 & $\$ 0$ & $\$ 138$ & $\$ 1,060$ \\
\hline \multirow{5}{*}{$\begin{array}{l}\text { 3- CONTROLLED } \\
\text { DENOUTON }\end{array}$} & $3 \cdot A$ & 100 & $(\$ 150)$ & 0 & $\$ 0$ & 0 & \$o & 0 & $\$ 0$ & \$o & (\$150) \\
\hline & $3 \cdot \mathbf{B}$ & 75 & (\$113) & 15 & $\$ 138$ & 10 & $\$ 1,516$ & 25 & $\$ 3,126$ & $\$ 717$ & $\$ 5,385$ \\
\hline & $3-C$ & 50 & (\$75) & 15 & $\$ 138$ & 35 & $\$ 5,307$ & 50 & $\$ 6,253$ & $\$ 1,755$ & $\$ 13,378$ \\
\hline & 3-D & 25 & (\$38) & 10 & $\$ 92$ & 65 & $\$ 9,856$ & 75 & $\$ 9,379$ & $\$ 2,899$ & $\$ 22,188$ \\
\hline & 3-E & 0 & $\$ 0$ & 0 & $\$ 0$ & 100 & $\$ 15,163$ & 100 & $\$ 12,506$ & $\$ 4,150$ & $\$ 31,818$ \\
\hline \multirow{5}{*}{$\begin{array}{l}4 \text { - ENCLOSED } \\
\text { DENOLITON } \\
\text { (ENEEOPB) }\end{array}$} & $4 \cdot A$ & 100 & $(\$ 150)$ & 0 & $\$ 0$ & 0 & \$o & 0 & $\$ 0$ & \$o & (\$150) \\
\hline & $4 \cdot B$ & 50 & $(\$ 75)$ & 50 & $\$ 461$ & 0 & \$o & 40 & $\$ 5,002$ & $\$ 819$ & $\$ 6,207$ \\
\hline & $4-C$ & 50 & (\$75) & 0 & $\$ 0$ & 50 & $\$ 7,581$ & 60 & $\$ 7,503$ & $\$ 2,263$ & $\$ 17,272$ \\
\hline & 4-D & 0 & \$o & 50 & $\$ 461$ & 50 & $\$ 7,581$ & 80 & $\$ 10,004$ & $\$ 2,707$ & $\$ 20,753$ \\
\hline & 4-E & 0 & \$o & 0 & \$o & 100 & $\$ 15,163$ & 100 & $\$ 12,506$ & $\$ 4,150$ & $\$ 31,818$ \\
\hline
\end{tabular}

\begin{tabular}{|c|c|}
\hline \multicolumn{2}{|c|}{ Dismantling Alternative Description } \\
\hline 1 & No dismantling action will take place. An additional third outer fence will be constructed. \\
\hline 2 & $\begin{array}{c}\text { Dismantling of the PPC facilities using state-ol-practice open air demolition activities. Debris to be stored in sealed containers and tested prior } \\
\text { to cornmence Phase } 2 \text { activities. }\end{array}$ \\
\hline 3 & $\begin{array}{c}\text { Dismantling activities on an enclosed floor-by-floor basis. Debris to be stored in sealed containers and tested prior to commence Phase } 2 \\
\text { activities }\end{array}$ \\
\hline 4 & $\begin{array}{c}\text { Dismantling activities on an enveloped building-by-buading basis. Debris to be stored in sealed containers and tested prior to commence } \\
\text { Phase } 2 \text { activities. }\end{array}$ \\
\hline
\end{tabular}


TABLE 3 Combined Cost Estimates for Phases 1 and 2

\begin{tabular}{|c|c|c|c|c|}
\hline \multirow{2}{*}{$\begin{array}{l}\text { DISMANTLING } \\
\text { ALTERNATIVE }\end{array}$} & \multirow{2}{*}{ SCENARIO } & \multicolumn{3}{|c|}{ ESTIMATED COST $(\$ 1,000)$} \\
\hline & & $\begin{array}{c}\text { PHASE } 1 \\
\text { DESIGN, SITE ACTIVITIES } \\
\text { ANDO \&M }\end{array}$ & $\begin{array}{c}\text { PHASE } 2 \\
\text { DISPOSITION } \\
\text { AND/OR TREATMENT }\end{array}$ & TOTAL \\
\hline 1- NO ACTION & $1-A$ & $\$ 410$ & $\$ 0$ & $\$ 410$ \\
\hline \multirow{5}{*}{$\begin{array}{l}\text { 2- CONVENTIONAL } \\
\text { DEMOLTION }\end{array}$} & $2-A$ & $\$ 3,061$ & $(\$ 150)$ & $\$ 2,911$ \\
\hline & $2-B$ & $\$ 3,061$ & $\$ 152$ & $\$ 3,214$ \\
\hline & $2-C$ & $\$ 3,061$ & $\$ 455$ & $\$ 3,516$ \\
\hline & 2-D & $\$ 3,061$ & $\$ 757$ & $\$ 3,819$ \\
\hline & $2-E$ & $\$ 3,061$ & $\$ 1,060$ & $\$ 4,121$ \\
\hline \multirow{5}{*}{$\begin{array}{l}\text { 3- CONTROLLLED } \\
\text { DEMOLITION }\end{array}$} & 3-A & $\$ 36,422$ & $(\$ 150)$ & $\$ 36,272$ \\
\hline & 3-B & $\$ 36,422$ & $\$ 5,385$ & $\$ 41,808$ \\
\hline & $3-\mathrm{C}$ & $\$ 36,422$ & $\$ 13,378$ & $\$ 49,800$ \\
\hline & 3-D & $\$ 36,422$ & $\$ 22,188$ & $\$ 58,611$ \\
\hline & 3-E & $\$ 36,422$ & $\$ 31.818$ & $\$ 68,241$ \\
\hline \multirow{5}{*}{$\begin{array}{l}4 \text { - ENCLOSED } \\
\text { DEMOLITION } \\
\text { (ENVELOPE) }\end{array}$} & $4-A$ & $\$ 51,024$ & $(\$ 150)$ & $\$ 50,874$ \\
\hline & $4-B$ & $\$ 51,024$ & $\$ 6,207$ & $\$ 57,231$ \\
\hline & $4-\mathrm{C}$ & $\$ 51.024$ & $\$ 17,272$ & $\$ 68,296$ \\
\hline & 4-D & $\$ 51,024$ & $\$ 20,753$ & $\$ 71,777$ \\
\hline & 4-E & $\$ 51.024$ & $\$ 31,818$ & $\$ 82,842$ \\
\hline
\end{tabular}

\begin{tabular}{|c|c|}
\hline \multicolumn{2}{|c|}{ Dismantling Alternative Description } \\
\hline 1 & No dismantling action will take place. An additional third outer fence will be constructed. \\
\hline 2 & $\begin{array}{c}\text { Dismantling of the PPC facilities using state-of-practice open air demolition activities. Debris to be } \\
\text { stored in sealed containers and tested prior to commence Phase } 2 \text { activities. }\end{array}$ \\
\hline 3 & $\begin{array}{c}\text { Dismantling activities on an enclosed floor-by-floor basis. Debris to be stored in sealed containers and } \\
\text { tested prior to commence Phase } 2 \text { activities }\end{array}$ \\
\hline 4 & Dismantling activities on an enveloped building-by-building basis. Debris to be stored in sealed \\
containers and tested prior to commence Phase 2 activities.
\end{tabular}


estimated costs were based on material quantity estimates and unit costs, as discussed in Section 5.3. Material quantity estimates were taken from the Documentation and Quantification Reports prepared by ANL for each of the nine PPC buildings (Draugelis et al. 1995a,b; Smits et al. 1995; O'Reilly et al. 1995a,b; Muir-Ploense et al. 1995; Miller et al. 1995; Zellmer et al. 1995a,b). A summary of the material quantity estimates for each of the PPC buildings is presented in Appendix A. Unit costs were selected for the different activities from the 1995 Environmental Restoration Unit Cost Book, published by Environmental Cost Handling Options and Solutions (ECHOS); the 1994 Means Building Construction Cost Data; and various sources within APG.

\subsection{Cost Estimates for Phase 1}

\subsubsection{No-Action Alternative}

The cost to implement the design, site activities, and operation and maintenance for the proposed no-action alternative is estimated to be $\$ 410,000$. Table 4 details the estimated costs to develop and implement the no-action dismantling alternative. Most of the cost of implementing this alternative $(\$ 270,000)$ is for operation and maintenance activities.

Limited design activities will be needed to implement this alternative, since an existingcondition assessment has already been conducted; however, there will be a need to prepare a Statement of Work for the proposed site activities.

The site activities will include minor repairs to the existing fence and construction of a third outer fence, to further isolate the PPC from the APG. Installation of additional security and a continuous surveillance system may be desirable and could be substituted for the third fence, but that possibility was not included in this cost estimate.

Operation and maintenance activities will be conducted for up to 30 years from the date the field work is concluded. The grass will be cut twice a month during the growing season. Annual inspections and reports will be made and minor repairs will be performed as needed. A limited budget of $\$ 5,000$ per year was established for such operations as removal of debris that falls off the aging buildings.

\subsubsection{Conventional Demolition Alternative}

The cost to implement the design, site activities, and operation and maintenance for the conventional demolition alternative is estimated to be just over $\$ 3$ million. Table 5 provides a breakdown of this estimated cost. 
TABLE 4 Cost Estimates for Phase 1 No-Action Alternative

SUMMARY $(\$ 1,000)$

\begin{tabular}{|l|r|}
\hline Task 1: DESIGN & $\$ 20$ \\
Task 2: SITE ACTIVITIES & $\$ 67$ \\
Task 3: OPERATION AND MAINTENANCE & $\$ 270$ \\
$15.00 \%$ Contingency & $\$ 53$ \\
DISMANTLING ALTERNATIVE 1 NO-ACTION TOTAL & $\$ 410$ \\
\hline
\end{tabular}

DETAIL

\begin{tabular}{|c|c|c|c|c|c|}
\hline \begin{tabular}{|c|} 
TASK \\
$\&$ \\
SUBTASK \\
\end{tabular} & DESCRIPTION & QUANTITY & UNIT & $\begin{array}{c}\text { UNIT } \\
\text { COST } \\
\text { (S/UNIT) }\end{array}$ & $\begin{array}{c}\text { TOTAL } \\
\text { COST } \\
(\$ 1,000) \\
\end{array}$ \\
\hline $\begin{array}{r}1 \\
1.1 \\
1.2 \\
1.2 .2 \\
1.2 .3 \\
1.2 .4 \\
1.2 .5 \\
1.2 .6\end{array}$ & $\begin{array}{l}\text { DESIGN } \\
\text { Facility Survey (Completed) } \\
\text { Design } \\
\text { Prepare Plans } \\
\text { Prepare Specifications } \\
\text { Prepare Bid Document } \\
\text { Obtain Design Approvals } \\
\text { Obtain Design Permit }\end{array}$ & $\begin{array}{l}60 \\
40 \\
60 \\
25 \\
25\end{array}$ & $\begin{array}{l}\text { manhour } \\
\text { manhour } \\
\text { manhour } \\
\text { manhour } \\
\text { manhour }\end{array}$ & $\begin{array}{l}95 \\
95 \\
95 \\
95 \\
95\end{array}$ & $\begin{array}{l}6 \\
4 \\
6 \\
2 \\
2\end{array}$ \\
\hline & N TASK CO & & & & $\$ 20$ \\
\hline
\end{tabular}

\begin{tabular}{|c|l|r|r|r|r|}
\hline $\begin{array}{c}\text { TASK } \\
\& \\
\text { SUBTASK }\end{array}$ & \multicolumn{1}{|c|}{ DESCRIPTION } & QUANTITY & UNIT & $\begin{array}{c}\text { UNIT } \\
\text { COST } \\
\text { (S/UNIT) }\end{array}$ & $\begin{array}{c}\text { TOTAL } \\
\text { COST } \\
(S 1,000)\end{array}$ \\
\hline 2 & SITE ACTIVITIES & & & & \\
2.1 & Minor Existing Fence Repairs & 100 & LF & 31 & 3 \\
2.2 & New Outer Third Fence & 1,890 & LF & 34 & 63 \\
\hline \multicolumn{2}{|c|}{ SITE ACTIVITIES TASK COST ESTIMATE } \\
\hline
\end{tabular}


TABLE 4 (Cont.)

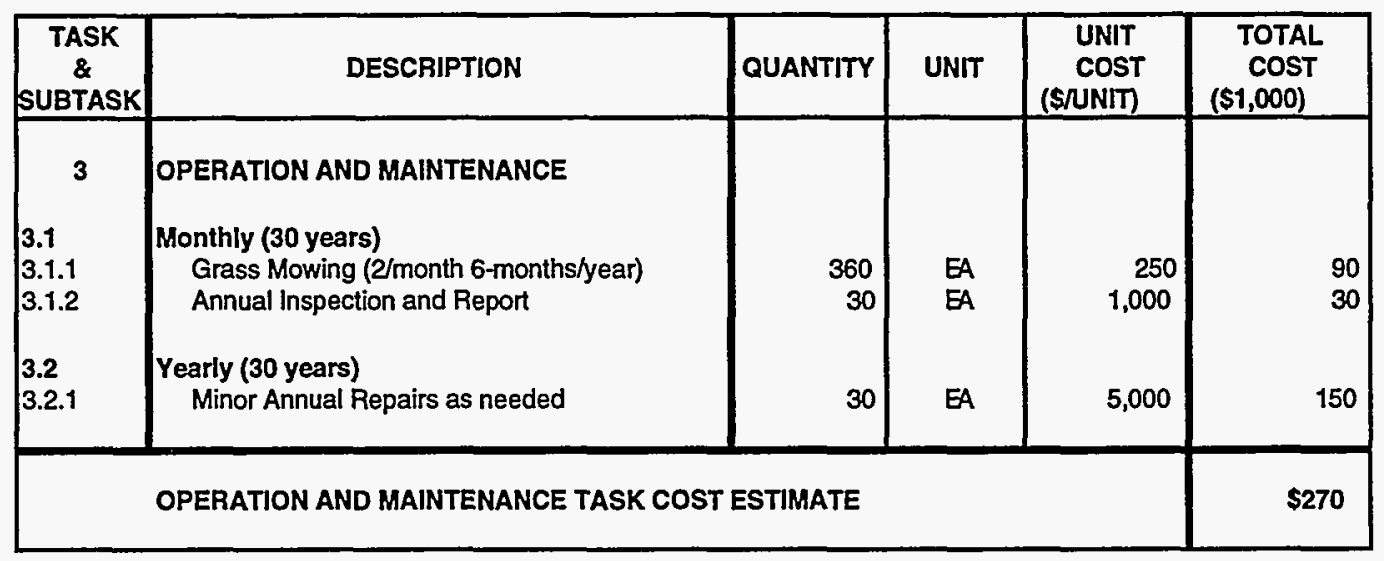

TABLE 5 Cost Estimates for Phase 1 Conventional Demolition Alternative

SUMMARY $(\$ 1,000)$

Task 1: DESIGN
Task 2: SITE ACTIVITIES
Task 3: OPERATION AND MAINTENANCE
$15.00 \%$ Contingency

DISMANTLING ALTERNATIVE 2 CONVENTIONAL DEMOLITION TOTAL

DETAIL

\begin{tabular}{|c|c|c|c|c|c|}
\hline $\begin{array}{c}\text { TASK } \\
\& \\
\text { SUBTASK } \\
\end{array}$ & DESCRIPTION & QUANTITY & UNIT & $\begin{array}{c}\text { UNIT } \\
\text { COST } \\
\text { (S/UNIT) }\end{array}$ & $\begin{array}{c}\text { TOTAL } \\
\text { COST } \\
(\$ 1,000)\end{array}$ \\
\hline $\begin{array}{l}1 \\
1.1 \\
1.2 \\
1.2 .1 \\
1.2 .2 \\
1.2 .3 \\
1.2 .4 \\
1.2 .5 \\
1.2 .6 \\
1.3 \\
1.3 .1 \\
1.3 .2 \\
1.3 .3 \\
1.3 .4 \\
1.3 .5 \\
1.3 .6\end{array}$ & $\begin{array}{l}\text { DESIGN } \\
\text { Facility Survey (Completed) } \\
\text { Design } \\
\text { Select Demolition Method } \\
\text { Prepare Plans } \\
\text { Prepare Specifications } \\
\text { Prepare Bid Document } \\
\text { Obtain Design Approvals } \\
\text { Obtain Design Permit } \\
\text { Bid Process } \\
\text { Obtain Bid Approval } \\
\text { Prepare Bid Pre-qualifications } \\
\text { Select and Pre-qualify Bidders } \\
\text { Prepare and Distribute invitation-For-Bid } \\
\text { Review Bids } \\
\text { Select and Recommend Bid Winner to APG }\end{array}$ & $\begin{array}{r}40 \\
250 \\
200 \\
180 \\
85 \\
85\end{array}$ & $\begin{array}{l}\text { manhour } \\
\text { manhour } \\
\text { manhour } \\
\text { manhour } \\
\text { manhour } \\
\text { manhour } \\
\text { manhour } \\
\text { manhour } \\
\text { manhour } \\
\text { manhour } \\
\text { manhour } \\
\text { manhour }\end{array}$ & $\begin{array}{l}95 \\
95 \\
95 \\
95 \\
95 \\
95\end{array}$ & $\begin{array}{r}4 \\
24 \\
19 \\
17 \\
8 \\
8\end{array}$ \\
\hline & DESIGN TASK COST ESTIMATE & & & & $\$ 100$ \\
\hline
\end{tabular}


TABLE 5 (Cont.)

DETAIL (Continued)

\begin{tabular}{|c|c|c|c|c|c|}
\hline $\begin{array}{c}\text { TASK } \\
\& \\
\& U B T A S K\end{array}$ & DESCRIPTION & QUANTITY & UNIT & $\begin{array}{c}\text { UNIT } \\
\text { COST } \\
\text { (S/UNIT) }\end{array}$ & $\begin{array}{c}\text { TOTAL } \\
\text { COST } \\
\text { (S1.000) }\end{array}$ \\
\hline 2 & SITE ACTIVITIES (Protection Level D) & & & & \\
\hline 2.1 & Contractor(s) Mobllization & & & & \\
\hline 2.1 .1 & Demolition Equipment & 1 & LS & 20,000 & 20 \\
\hline 2.1 .2 & Field Office & 1 & LS & 10,000 & 10 \\
\hline 2.1 .3 & Initiat e Dust Monitoring & 1 & LS & 15,000 & 15 \\
\hline 2.2 & Site Preparation & & & & \\
\hline 2.2 .1 & Barriers and Enclosures & 1 & LS & 7,500 & 8 \\
\hline 2.2 .2 & Security & 1 & LS & 10,000 & 10 \\
\hline 2.2 .3 & Access Poads (Stone,12-ft Wide, 6-in deep) & 100 & LF & $\begin{array}{r}81 \\
15000\end{array}$ & $\begin{array}{r}8 \\
15\end{array}$ \\
\hline $\begin{array}{l}2.2 .4 \\
2.2 .5\end{array}$ & $\begin{array}{l}\text { Temporary Runoff Controls ( } 10 \text { ac-ft pond) } \\
\text { Temporary Slt Runoff Controls }\end{array}$ & $\begin{array}{r}1 \\
1,890\end{array}$ & $\begin{array}{l}\text { LS } \\
\text { LF }\end{array}$ & $\begin{array}{r}15,000 \\
1\end{array}$ & $\begin{array}{r}15 \\
3\end{array}$ \\
\hline 2.2 .6 & Project Signs & 1 & LS & 2,500 & 3 \\
\hline 2.3 & Pre-Demolition Activities & & & & \\
\hline 2.3 .1 & $\begin{array}{l}\text { Pemove: } \\
\text { Asbestos (Transite and Vinul) }\end{array}$ & 7140 & $\mathbf{S F}$ & ? & 15 \\
\hline 2.3 .1 .2 & Windows & 6,526 & SF & 2 & 12 \\
\hline 2.3 .1 .3 & Metal and Wood Door Pemoval & 190 & $\mathbf{S F}$ & 12 & 2 \\
\hline 2.3 .1 .4 & Metal and Wood Door Frame Pemoval & 248 & SF & 23 & 6 \\
\hline $\begin{array}{l}2.3 .1 .5 \\
2.3 .2\end{array}$ & $\begin{array}{l}\text { Miscellaneous Metals } \\
\text { Public Pelations Consultant }\end{array}$ & $\begin{array}{r}8 \\
40\end{array}$ & $\begin{array}{c}\text { TON } \\
\text { manhour }\end{array}$ & $\begin{array}{r}939 \\
95\end{array}$ & $\begin{array}{l}8 \\
4\end{array}$ \\
\hline 2.3 & St andard & & & & \\
\hline 2.3 .1 & Dust Control & 1 & LS & 45,000 & 45 \\
\hline $\begin{array}{l}2.3 .2 \\
2.3 .2 .1\end{array}$ & $\begin{array}{l}\text { Building Mass Demolition } \\
\text { Gravel Poofing }\end{array}$ & 28,846 & SF & 1 & 18 \\
\hline 2.3 .2 .2 & Interior Walls & 45,516 & SF & 1 & 50 \\
\hline 2.3 .2 .3 & Exterior Walls & 48,453 & $\mathbf{S F}$ & 1 & 60 \\
\hline 2.3 .2 .4 & Concrete Sabs & 1,975 & $\mathrm{CF}$ & 2 & 4 \\
\hline 2.3 .2 .5 & $\begin{array}{l}\text { Seel Framing } \\
\text { Sab on Grade }\end{array}$ & $\begin{array}{r}653 \\
40.511\end{array}$ & $\underset{S F}{\operatorname{TON}}$ & $\begin{array}{r}200 \\
1\end{array}$ & $\begin{array}{r}131 \\
28\end{array}$ \\
\hline 2.3.2.7 & Miscellaneous Labor Activities & 500 & HR & 47 & 23 \\
\hline 2.3 .3 & Remove Site Substructure & & & & \\
\hline 2.3 .3 .1 & Sidewalks & 26 & cY & 33 & 1 \\
\hline 2.3.3.2 & Poads & & & & \\
\hline 2.3.3.2.1 & $\begin{array}{l}\text { Concrete } \\
\text { Asphalt }\end{array}$ & 232 & $C Y$ & $\begin{array}{l}55 \\
25\end{array}$ & $\begin{array}{r}13 \\
3\end{array}$ \\
\hline $\begin{array}{l}2.3 .3 .2 .2 \\
2.3 .3 .3\end{array}$ & $\begin{array}{l}\text { Asphalt } \\
\text { Barbed-wire Fences }\end{array}$ & $\begin{array}{r}171 \\
3.353\end{array}$ & LY & $\begin{array}{l}25 \\
31\end{array}$ & $\begin{array}{r}3 \\
103\end{array}$ \\
\hline
\end{tabular}


TABLE 5 (Cont.)

DETAIL (Continued)

\begin{tabular}{|c|c|c|c|c|c|}
\hline $\begin{array}{c}\text { TASK } \\
\& \\
\text { SUETASK }\end{array}$ & DESCAIPTION & QUANTITY & UNIT & $\begin{array}{c}\text { UNIT } \\
\text { COST } \\
\text { (S/UNIT) }\end{array}$ & $\begin{array}{c}\text { TOTAL } \\
\text { COST } \\
(\$ 1.000)\end{array}$ \\
\hline $\begin{array}{l}2.4 \\
2.4 .1 \\
2.4 .2 \\
2.4 .3 \\
2.4 .4 \\
2.4 .5 \\
2.4 .6\end{array}$ & $\begin{array}{l}\text { Demobilization and Site } \\
\text { Pegrade (100,000-SF } 1 \text {-ft thick) } \\
\text { Low Permeability Cover } \\
\text { Top Soil (100,00-SF 6-in.) } \\
\text { Seed } \\
\text { Pemove Barriers,Security, Sgns, etc. } \\
\text { Contract or Demobilization }\end{array}$ & $\begin{array}{r}5,550 \\
5 \\
1,850 \\
5 \\
1 \\
1\end{array}$ & $\begin{array}{l}\text { CY } \\
\text { ACFE } \\
\text { CY } \\
\text { ACFE } \\
\text { LS } \\
\text { LS }\end{array}$ & $\begin{array}{r}3 \\
287,500 \\
25 \\
444 \\
5,000 \\
20,000\end{array}$ & $\begin{array}{r}15 \\
1,438 \\
46 \\
2 \\
5 \\
20\end{array}$ \\
\hline & SITE ACTIVITIES (LeveI D) TASK COST & & & & $\$ 2,142$ \\
\hline
\end{tabular}

\begin{tabular}{|c|c|c|c|c|c|}
\hline $\begin{array}{c}\text { TASK } \\
\text { \& } \\
\text { SUBTASK }\end{array}$ & DESCRIPTION & QUANTITY & UNIT & $\begin{array}{c}\text { UNIT } \\
\text { COST } \\
\text { (S/UNIT) }\end{array}$ & $\begin{array}{c}\text { TOTAL } \\
\text { COST } \\
\text { (S1,000) }\end{array}$ \\
\hline \begin{tabular}{l}
\multicolumn{1}{c}{3} \\
3.1 \\
3.1 .1 \\
3.1 .2 \\
3.2 \\
3.2 .1
\end{tabular} & $\begin{array}{l}\text { OPERATION AND } \\
\text { Mont hly ( } 30 \text { years) } \\
\text { Grass Mowing ( } 2 / \text { month } 6 \text { months/year) } \\
\text { Annual Inspection and Peport } \\
\text { Yearly ( } 30 \text { years) } \\
\text { Annual Pepairs as needed }\end{array}$ & $\begin{array}{r}360 \\
30\end{array}$ & $\begin{array}{l}\text { EA } \\
E A\end{array}$ & $\begin{array}{r}250 \\
1,000\end{array}$ & $\begin{array}{l}90 \\
30\end{array}$ \\
\hline & OPERATION AND MAINTENANCE TAS & & & & $\$ 420$ \\
\hline
\end{tabular}

The design activities will include preparing project plans, health and safety plans, and standard operation procedures. A facility survey has already been completed by ANL as part of a separate contract. Design approvals and permits will be obtained as needed.

Implementation of the conventional demolition alternative assumes that none of the dust generated during demolition of the PPC buildings will be contaminated by chemical agents or any other listed hazardous or toxic materials. Accordingly, personnel involved with the field dismantling activities will not be required to use any personal protective clothing and equipment for such agents or any other listed hazardous or toxic materials. However, each person will be required to use OSHA Level D personal protective clothing and equipment, including a Tyvex suit with hood, a safety hat, boots having steel toes and shanks, and gloves.

Site activities will, at the least, include contractor mobilization, site preparation, predemolition activities, conventional demolition, demobilization, and site restoration.

Contractor mobilization will include on-site mobilization of demolition equipment and temporary field offices and the initiation of the dust-monitoring program. 
Site preparation activities will include barrier construction, construction of required access roads for demolition equipment, temporary runoff controls, and mobilization of field offices and demolition equipment. The temporary runoff controls will include a sedimentation pond capable of holding surface runoff from the PPC due to a 10-year, 24-hour-recurrence precipitation event. Construction access roads will be at least 12 -ft wide, of all-weather type, and consist of a layer of crushed stone that is at least 6 -in. thick.

Predemolition activities will include removal of any miscellaneous metals and any asbestos-containing materials such as pipe insulation, transite, or vinyl flooring. Public relations will be handled by APG and will deal with any public relations issues that may develop during the proposed demolition activities.

The PPC structures will be collapsed in their entirety using one or a combination of various conventional demolition techniques. Conventional demolition techniques that may be considered by the contractor include the wrecking ball, impact rams, breakers, diamond-tipped cutting tools, flame- or water-cutting equipment, or explosives. A description of the proposed conventional demolition techniques is presented in Section 3.1.2. A dust-monitoring program will be established as part of the conventional demolition activities, to verify that air-quality standards for particulate matter are not exceeded. The demolished debris will be reduced in size by either cutting it in place or crushing it, as needed.

Demobilization and site restoration will include demobilization of contractor equipment and temporary facilities; removal of barriers, temporary security, and signs; regrading $100,000 \mathrm{ft}^{2}$ of land with a 1-ft-thick layer of dirt; topsoiling approximately 5 acres with a 6-in. thick layer of topsoil; and seeding the entire PPC area (approximately 5 acres).

Operation and maintenance activities will be conducted for up to 30 years from the date the field work is concluded. The grass will be cut twice a month during the growing season, annual inspections will be conducted, and minor repairs will be performed as needed. A limited maintenance budget of $\$ 10,000$ per year was established for minor grass and erosion-control repairs.

\subsubsection{Controlled Demolition Alternative}

The cost to implement the design, site activities, and operation and maintenance for the proposed controlled demolition alternative is estimated to be $\$ 36.4$ million. Table 6 presents the estimated costs involved.

The design activities will include preparing project plans, health and safety plans, and standard operation procedures and implementing a bid process. Monitoring, testing protocols, and laboratory testing procedures for sampling and analysis of the demolition debris will also be developed. 
TABLE 6 Cost Estimates for Phase 1 Controlled Demolition Alternative

SUMMARY $(\$ 1,000)$

\begin{tabular}{|l|r|}
\hline Task 1:DESIGN & $\$ 475$ \\
Task 2: SITE ACTIVITIES & $\$ 30,777$ \\
Task $3:$ OPERATION AND MAINTENANCE & $\$ 420$ \\
$15.00 \%$ & $\$ 4,751$ \\
DISMANTLING ALTERNATIVE 3 CONTROLLED DEMOLITION TOTAL & $\$ 36,422$ \\
\hline
\end{tabular}

DETAIL

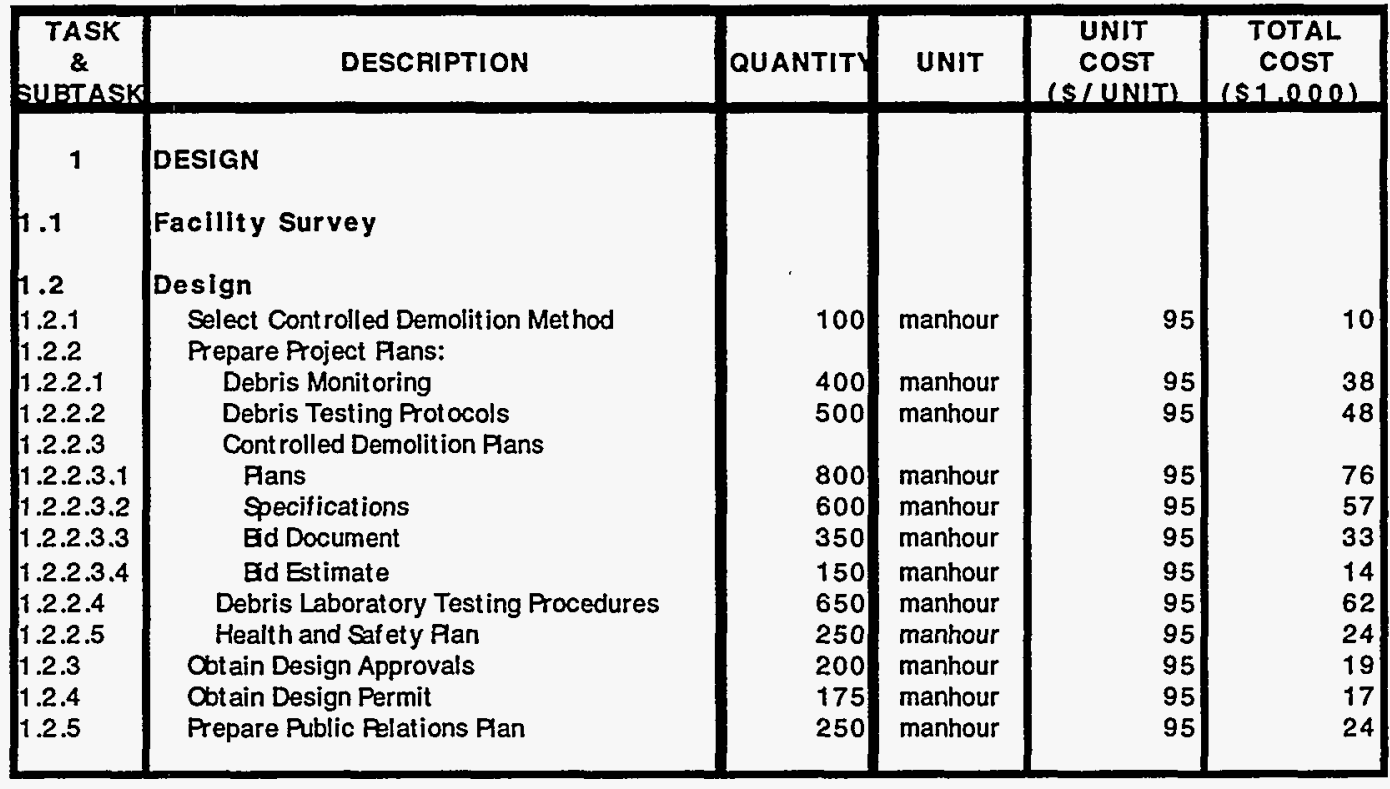


TABLE 6 (Cont.)

DETAIL

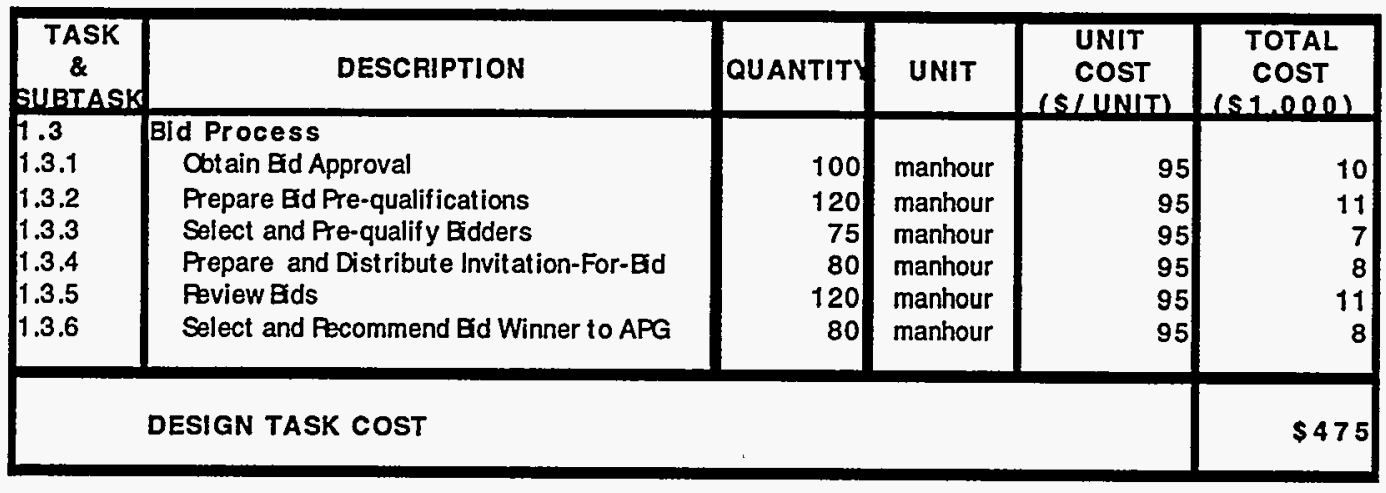

\begin{tabular}{|c|c|c|c|c|c|}
\hline $\begin{array}{c}\text { TASK } \\
\& \\
\text { SURIASK } \\
\end{array}$ & DESCRIPTION & QUANTITY & UNIT & $\begin{array}{c}\text { UNIT } \\
\text { COST } \\
\text { (S/UNIT) }\end{array}$ & $\begin{array}{c}\text { TOTAL } \\
\text { COST } \\
(S 1.000)\end{array}$ \\
\hline \begin{tabular}{l}
\multicolumn{1}{c}{2} \\
2.1 \\
2.1 .1 \\
2.1 .2 \\
2.1 .3 \\
2.1 .3 .1 \\
2.1 .3 .2 \\
2.2 \\
2.2 .1 \\
2.2 .2 \\
2.2 .3 \\
2.2 .4 \\
2.2 .5 \\
2.2 .6 \\
2.3 \\
2.3 .1 \\
2.3 .1 .1 \\
2.3 .1 .2 \\
2.3 .2 \\
2.4 \\
2.4 .1 \\
2.4 .1 .1 \\
2.4 .1 .2 \\
2.4 .1 .3
\end{tabular} & $\begin{array}{l}\text { SITE ACTIVITIES (Level B) } \\
\text { Contract or (s) } \\
\text { Demolition Equipment } \\
\text { Field Office } \\
\text { Install and Initiat e: } \\
\text { Dust Monitoring } \\
\text { Debris Monitoring } \\
\text { site Preparation } \\
\text { Barriers and Enclosures } \\
\text { Security } \\
\text { Access Poads (Stone, 12-ft wide, } 6 \text {-in Deep) } \\
\text { Temporary Punoff Controls (10-ac-ft pond) } \\
\text { Temporary SIt Punoff Controls } \\
\text { Project Signs } \\
\text { Pre- Demolit ion Act Ivit ies } \\
\text { Femove: } \\
\text { Asbestos and Heavy Metals as } \\
\text { Miscellaneous Metals } \\
\text { Public Pelations } \\
\text { Environment al } \\
\text { Foor by Foor Install and Pemove } \\
\text { Enclosure Envelope } \\
\text { Negative Air System (4-Vol/hr) } \\
\text { Dust Control Device }\end{array}$ & $\begin{array}{r}1 \\
1 \\
\\
1 \\
1 \\
100 \\
1 \\
500 \\
1\end{array}$ & $\begin{array}{c}\text { SF } \\
1,000 \mathrm{CFM} \\
1,000 \mathrm{CFM}\end{array}$ & $\begin{array}{r}20,000 \\
10,000 \\
15,000 \\
50,000 \\
\\
15,000 \\
35,000 \\
120 \\
50,000 \\
81 \\
5,000\end{array}$ & $\begin{array}{r}4,686 \\
431 \\
258\end{array}$ \\
\hline
\end{tabular}


TABLE 6 (Cont.)

DETAIL (Continued)

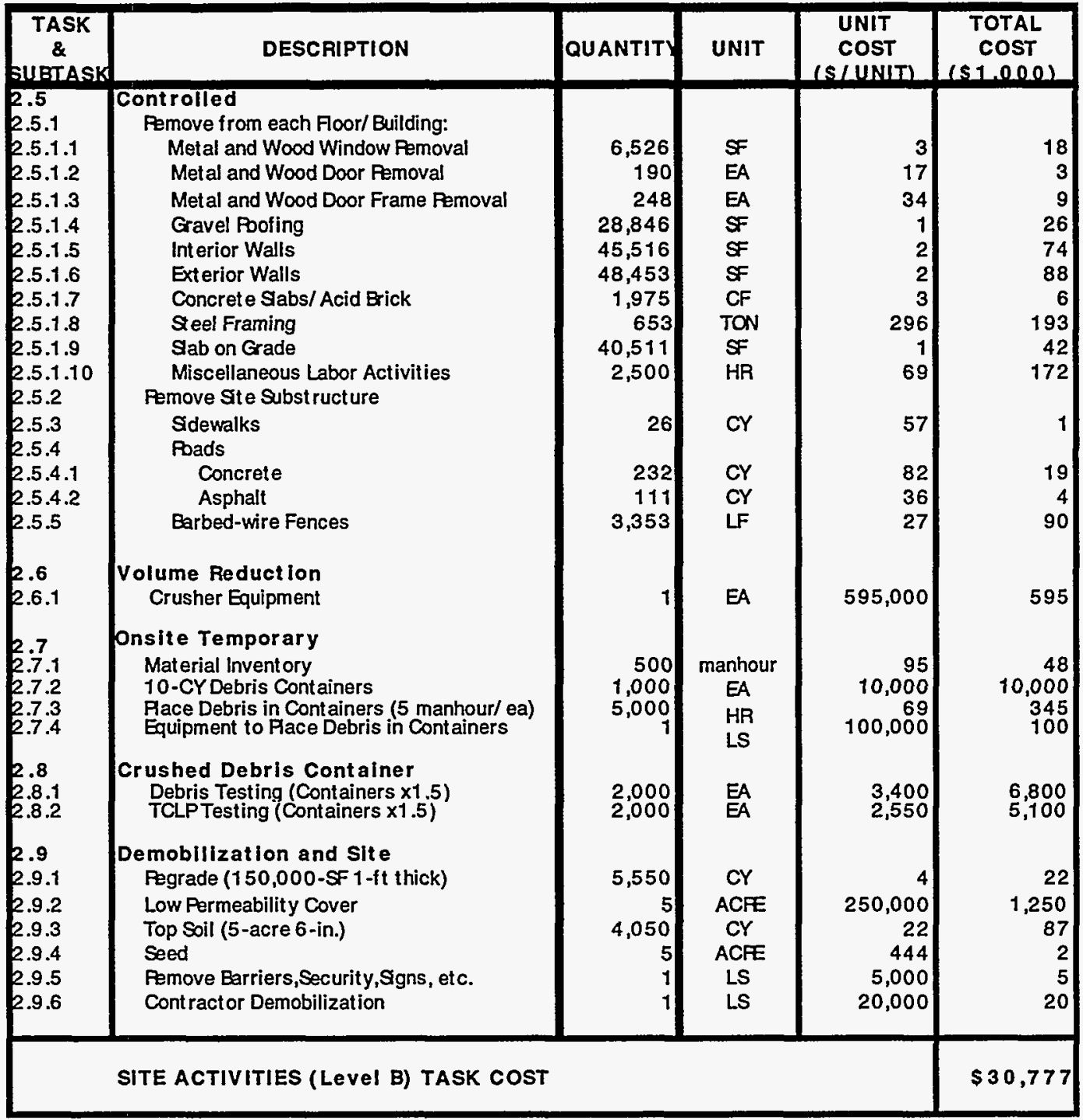


TABLE 6 (Cont.)

DETAIL

\begin{tabular}{|c|c|c|c|c|c|}
\hline $\begin{array}{c}\text { TASK } \\
\& \\
\text { SUBTASK }\end{array}$ & DESCRIPTION & QUANTITY & UNIT & $\begin{array}{c}\text { UNIT } \\
\text { COST } \\
\text { (S/UNIT) }\end{array}$ & $\begin{array}{c}\text { TOTAL } \\
\text { COST } \\
\text { (S1 }\end{array}$ \\
\hline $\begin{array}{l}\quad 3 \\
3.1 \\
3.1 .1 \\
3.1 .2 \\
3.2 \\
3.2 .1\end{array}$ & $\begin{array}{l}\text { OPERATION AND } \\
\text { Monthly ( } 30 \text { years) } \\
\text { Grass MOwing ( } 2 / \text { month } 6 \text { months/year) } \\
\text { Annual Inspection and Peport } \\
\text { Yearly ( } 30 \text { years) } \\
\text { Annual Pepairs as needed }\end{array}$ & $\begin{array}{r}360 \\
30\end{array}$ & $\begin{array}{l}E A \\
E A \\
E A\end{array}$ & $\begin{array}{r}250 \\
1,000 \\
10,000\end{array}$ & $\begin{array}{r}90 \\
30 \\
300\end{array}$ \\
\hline & OPERATION AND MAINTENANCE TAS & & & & $\$ 420$ \\
\hline
\end{tabular}

Implementation of the controlled demolition alternative assumes that personnel working within the controlled environment may be exposed to chemical agents and other listed hazardous or toxic materials. Therefore, each person involved with the field dismantling activities will be required to use OSHA Level $B$ personal protective clothing and equipment, including a Tyvex suit with hood, a safety hat, a self-contained breathing apparatus or supplied air, a full-face respirator, chemical-resistant boots having steel toes and shanks, and gloves. Contractor mobilization will include on-site mobilization of the demolition equipment and temporary field offices and initiation of the debris-monitoring and dust (vapor) control programs.

Site preparation will include erecting protective barriers and environmental enclosures, establishing construction security, constructing access roads and temporary surface runoff and silt controls, and placing project signs. The temporary runoff controls will include a sedimentation pond capable of holding surface runoff from the PPC buildings due to a 10-year, 24-hour-recurrence precipitation event. Construction access roads will be of an all-weather type that is at least 12-ft wide and consists of a layer of crushed stones at least 6-in. thick. Environmental enclosures will be required to minimize dust particulate escape from the controlled demolition activities at the PPC site. Accordingly, each enclosure envelope will be installed on a floor-by-floor basis prior to the initiation of the controlled demolition activities. In addition, a negative air-pressure system capable of handling at least four volume changes per hour and which includes an adequate air-filtering system will be installed.

When estimating the cost of the floor-to-floor enclosure envelope, a 50 percent contingency was added to the 105,000 square feet of exterior walls and roof surfaces of the buildings at the PPC. The negative air-pressure system and dust-control device were both sized for an anticipated maximum capacity of 101,000 cubic feet per minute (cfm), which corresponds to enclosing the first and second floors of Building E5625 and the size-reduction crusher equipment. These two floors have a combined capacity of 338,000 cubic feet, and the crusher equipment enclosure will require a temporary 100 - $\mathrm{ft}$ by 200 -ft building that has an average height of $35 \mathrm{ft}$. This temporary building will add over 675,000 cubic feet of interior volume. The capacity of the negative air-pressure system includes a 50 percent redundancy. 
Predemolition activities include removing any suspected asbestos-containing materials (such as transite or vinyl floor tile) and any miscellaneous metals found in each PPC building at the time of its demolition. At this time, APG personnel will be involved with any public relation issues that may develop during the implementation of the proposed demolition activities.

The controlled demolition activities at each building will begin by removing the interior metal-and-wood windows, doors and door frames, and the roof, if applicable, and proceed to the removal of the interior walls. All of this work will be done on a floor-by-floor basis, with the exterior walls on each floor being removed after the interior walls have been removed. PPC building structures will be razed, including the floor slabs.

Structural foundations and any other below-grade structures (such as sumps or utility systems) will be left in place. Sumps and utility systems will be filled with concrete after the water has been pumped out. The water will be tested and, depending on the test results, disposed of appropriately. The cost to treat the sumps and utility systems is estimated to be between $\$ 50,000$ and $\$ 500,000$ and is included in the contingency budget. Site infrastructure will also be removed, including the sidewalks, concrete and asphalt roads, and barbed-wire fences.

The controlled demolition debris will be reduced in volume by using crusher equipment capable of delivering crushed material that is approximately 1-1/2-in. in diameter. The crushed material will be temporarily stored on-site in 10- to 20 -cubic-yard sealed containers that will be designed for the purpose. The origin of the material going into each sealed container will be inventoried. One thousand 10-cubic-yard sealed containers are estimated to be needed for this alternative.

A comprehensive program to test debris containers for chemical agents and hazardous wastes (toxic characterization leaching procedure [TCLP] compounds) will be implemented. Air and solid samples will be tested for agents, and solid samples will be tested for TCLP compounds. An average of 1.5 tests per sealed container will be conducted.

Demobilization and site restoration will include the demobilization of contractor equipment and temporary facilities; removal of barriers, temporary security, and signs; regrading up to 150,000 square feet with an average 1-ft-thick layer of dirt; placing a low-permeability layer to reduce rainfall infiltration; topsoiling approximately 5 acres with an average 6-in.-thick layer of topsoil; and seeding the entire PPC area (approximately 5 acres).

Operation and maintenance activities are budgeted for 30 years from the date the field work is concluded. Operation and maintenance activities will include grass mowing, routine inspections, and minor surface repairs. The grass will be cut twice a month during the growing season. Annual inspections will be conducted, and minor repairs will be performed as needed. A limited budget of $\$ 10,000$ per year was established for minor grass and erosion-control repairs. 


\subsubsection{Enclosed Demolition Alternative}

The cost to implement the design, site activities, and operation and maintenance for the enclosed demolition alternative is estimated to be more than $\$ 51$ million. A breakdown of the estimated costs to implement this alternative is shown in Table 7.

The design activities will include preparing project plans, health and safety plans, and standard operation procedures and implementing a bid process. Monitoring, testing protocols, and laboratory testing procedures for the sampling and analysis of demolition debris will also be developed.

Implementation of the enclosed demolition alternative assumes that personnel working within the enclosed environment may be exposed to agents and other listed hazardous or toxic materials. Therefore, each person involved with the field dismantling activities will be required to use OSHA Level B personal protective clothing and equipment, including a Tyvex suit with hood, a safety hat, a self-contained breathing apparatus or supplied air, a full-face respirator, chemical-resistant boots having steel toes and shanks, and gloves.

During the design phase, a specific enclosed demolition method will be selected, and plans and specifications for carrying out these actions will be developed. The demolition will be carried out by initially constructing an enclosure over the PPC buildings. Monitoring, testing protocols, and laboratory testing procedures for the debris will also be developed.

Site activities will, at the least, include contractor mobilization, site preparation, predemolition activities, environmental controls, enclosed demolition, volume reduction, debris storage, debris-container testing, demobilization, and site restoration.

Contractor mobilization will include site mobilization of the demolition equipment and temporary field offices. The debris-monitoring and dust (vapor) control programs will also be initiated.

Site preparation will include erection of protective barriers and environmental enclosures, construction security, construction of access roads and temporary surface runoff and silt controls, and project signs. Temporary runoff controls will include the construction of a sedimentation pond capable of holding surface runoff from the PPC due to a 10-year, 24-hourrecurrence precipitation event. Construction access roads will be of an all-weather type that consists, at the least, of a 6-in.-thick layer of crushed stone and is $12 \mathrm{ft}$ wide.

Predemolition activities will include removal of suspected asbestos-containing materials (such as transite or vinyl) and miscellaneous metals found in the PPC buildings at the time of their demolition. APG personnel will be involved at this time with any public relation issues that may develop during the proposed demolition activities. 
TABLE 7 Cost Estimates for Phase 1 Enclosed Demolition Alternative

SUMMARY $(\$ 1,000)$

\begin{tabular}{|l|r|}
\hline Task 1 :DESIGN & $\$ 616$ \\
Task 2 :SITE ACTIVITIES & $\$ 43,332$ \\
Task $3:$ OPERATION AND & $\$ 420$ \\
$15.00 \%$ & $\$ 6,655$ \\
DISMANTLING ALTERNATIVE 4 ENCLOSED DEMOLITION TOTAL & $\$ 51,024$ \\
\hline
\end{tabular}

DETAIL

\begin{tabular}{|c|c|c|c|c|c|}
\hline $\begin{array}{c}\text { TASK } \\
\& \\
\text { SUBTASK }\end{array}$ & DESCRIPTION & QUANTITY & UNIT & $\begin{array}{c}\text { UNIT } \\
\text { COST } \\
\text { (S/UNIT) }\end{array}$ & $\begin{array}{c}\text { TOTAL } \\
\text { COST } \\
\text { (S1.00 }\end{array}$ \\
\hline \begin{tabular}{l|}
\multicolumn{1}{c|}{1} \\
1.1 \\
1.2 \\
1.2 .1 \\
1.2 .2 \\
1.2 .2 .1 \\
1.2 .2 .2 \\
1.2 .2 .3 \\
1.2 .2 .3 .1 \\
1.2 .2 .3 .2 \\
1.2 .2 .3 .3 \\
1.2 .2 .3 .4 \\
1.2 .2 .4 \\
1.2 .2 .5 \\
1.2 .3 \\
1.2 .4 \\
1.2 .5
\end{tabular} & $\begin{array}{l}\text { DESIGN } \\
\text { Facility Survey (Completed) } \\
\text { DesIgn } \\
\text { Select Enclosed Demolition Method } \\
\text { Prepare Project Pans: } \\
\text { Agent Monitoring } \\
\text { Agent Testing Protocols } \\
\text { Enclosed Demolition Fans } \\
\text { Rans } \\
\text { Specifications } \\
\text { Bd Document } \\
\text { Ed Estimate } \\
\text { Agent Laboratory Testing Procedures } \\
\text { Health and Saf ety Pan } \\
\text { Obtain Design Approvals } \\
\text { Obtain Design Permit } \\
\text { Prepare Public Pelations Plan }\end{array}$ & $\begin{array}{r}150 \\
\\
450 \\
560 \\
\\
1,000 \\
850 \\
450 \\
250 \\
1,000 \\
400 \\
250 \\
200 \\
350\end{array}$ & $\begin{array}{l}\text { manhour } \\
\text { manhour } \\
\text { manhour } \\
\text { manhour } \\
\text { manhour } \\
\text { manhour } \\
\text { manhour } \\
\text { manhour } \\
\text { manhour } \\
\text { manhour } \\
\text { manhour } \\
\text { manhour }\end{array}$ & $\begin{array}{l}95 \\
95 \\
95 \\
95 \\
95 \\
95 \\
95 \\
95 \\
95 \\
95 \\
95 \\
95\end{array}$ & $\begin{array}{l}95 \\
81 \\
43 \\
24 \\
95 \\
38 \\
24 \\
19 \\
33\end{array}$ \\
\hline
\end{tabular}


TABLE 7 (Cont.)

DETAIL (Continued)

\begin{tabular}{|c|c|c|c|c|c|}
\hline $\begin{array}{c}\text { TASK } \\
\& \\
\text { SUBTASK }\end{array}$ & DESCRIPTION & QUANTITY & UNIT & $\begin{array}{c}\text { UNIT } \\
\text { COST } \\
\text { (S/UNIT) }\end{array}$ & $\begin{array}{c}\text { TOTAL } \\
\text { COST } \\
(S 1.000)\end{array}$ \\
\hline $\begin{array}{l}1.3 \\
1.3 .1 \\
1.3 .2 \\
1.3 .3 \\
1.3 .4 \\
1.3 .5 \\
1.3 .6\end{array}$ & $\begin{array}{l}\text { Bid Process } \\
\text { Obtain Ed Approval } \\
\text { Prepare Bid Pre-qualifications } \\
\text { Select and Pre-qualify Edders } \\
\text { Prepare and Distribute Invitation-For-Bid } \\
\text { Peview Eds } \\
\text { Select and Pecommend Ed Winner to APG }\end{array}$ & $\begin{array}{r}100 \\
120 \\
75 \\
80 \\
120 \\
80\end{array}$ & $\begin{array}{l}\text { manhour } \\
\text { manhour } \\
\text { manhour } \\
\text { manhour } \\
\text { manhour } \\
\text { manhour }\end{array}$ & $\begin{array}{l}95 \\
95 \\
95 \\
95 \\
95 \\
95\end{array}$ & $\begin{array}{r}10 \\
11 \\
7 \\
8 \\
11 \\
8\end{array}$ \\
\hline & ESIGN TASK COST & & & & $\$ 616$ \\
\hline
\end{tabular}

\begin{tabular}{|c|c|c|c|c|c|}
\hline $\begin{array}{c}\text { TASK } \\
\& \\
\text { SUBTASK }\end{array}$ & DESCRIPTION & QUANTITY & UNIT & $\begin{array}{c}\text { UNIT } \\
\text { COST } \\
\text { (S LUNIT) }\end{array}$ & $\begin{array}{c}\text { TOTAL } \\
\text { COST } \\
(S 1.0 .00)\end{array}$ \\
\hline \begin{tabular}{l}
\multicolumn{1}{c}{$\quad$ } \\
2.1 \\
2.1 .1 \\
2.1 .2 \\
2.1 .3 \\
2.1 .3 .1 \\
2.1 .3 .2 \\
2.2 \\
2.2 .1 \\
2.2 .2 \\
2.2 .3 \\
2.2 .4 \\
2.2 .5 \\
2.3 \\
2.3 .1 \\
2.3 .1 .1 \\
2.3 .1 .2 \\
2.3 .2 \\
2.4 \\
2.4 .1 \\
2.4 .1 .2 \\
2.4 .1 .2 .1 \\
2.4 .1 .2 .2 \\
2.4 .1 .3 \\
2.4 .1 .4
\end{tabular} & $\begin{array}{l}\text { SITE ACTIVITIES (Level B) } \\
\text { Cont ract or(s) } \\
\text { Demolition Equipment } \\
\text { Field Ofice } \\
\text { Install and Initiate: } \\
\text { Agent Monitoring } \\
\text { Dust Control } \\
\text { Sit e Pre paration } \\
\text { Barriers and Enclosures } \\
\text { Security } \\
\text { Access } \\
\text { Temporary Runoff Cont rols } \\
\text { Project \$gns } \\
\text { Pre-Demolit Ion Act Ivities } \\
\text { Pemove: } \\
\text { Asbestos and Heavy Metals as } \\
\text { Miscellaneous Metals } \\
\text { Public Pelations } \\
\text { Environment al } \\
\text { Building by Building Install and Pemove } \\
\text { Individual Building Tent Envelope } \\
\text { Bdg } 5625 \\
\text { Oher Buildings } \\
\text { Dust Control Device } \\
\text { Negative Air System (4-Vol/hr) }\end{array}$ & $\begin{array}{r}1 \\
1 \\
100 \\
1 \\
500 \\
1 \\
\\
100 \\
200 \\
100\end{array}$ & $\begin{array}{c}\text { SF } \\
\text { EA } \\
1,000 \mathrm{CFM} \\
1,000 \mathrm{CFM}\end{array}$ & $\begin{array}{r}6,000 \\
3,000 \\
\\
50,000 \\
25,000 \\
\\
7,500 \\
20,000 \\
120 \\
15,000 \\
81 \\
5,000 \\
\\
69 \\
69 \\
95\end{array}$ & $\begin{array}{l}9,350 \\
1,020 \\
2,831 \\
4,718\end{array}$ \\
\hline
\end{tabular}


TABLE 7 (Cont.)

DETAIL (Continued)

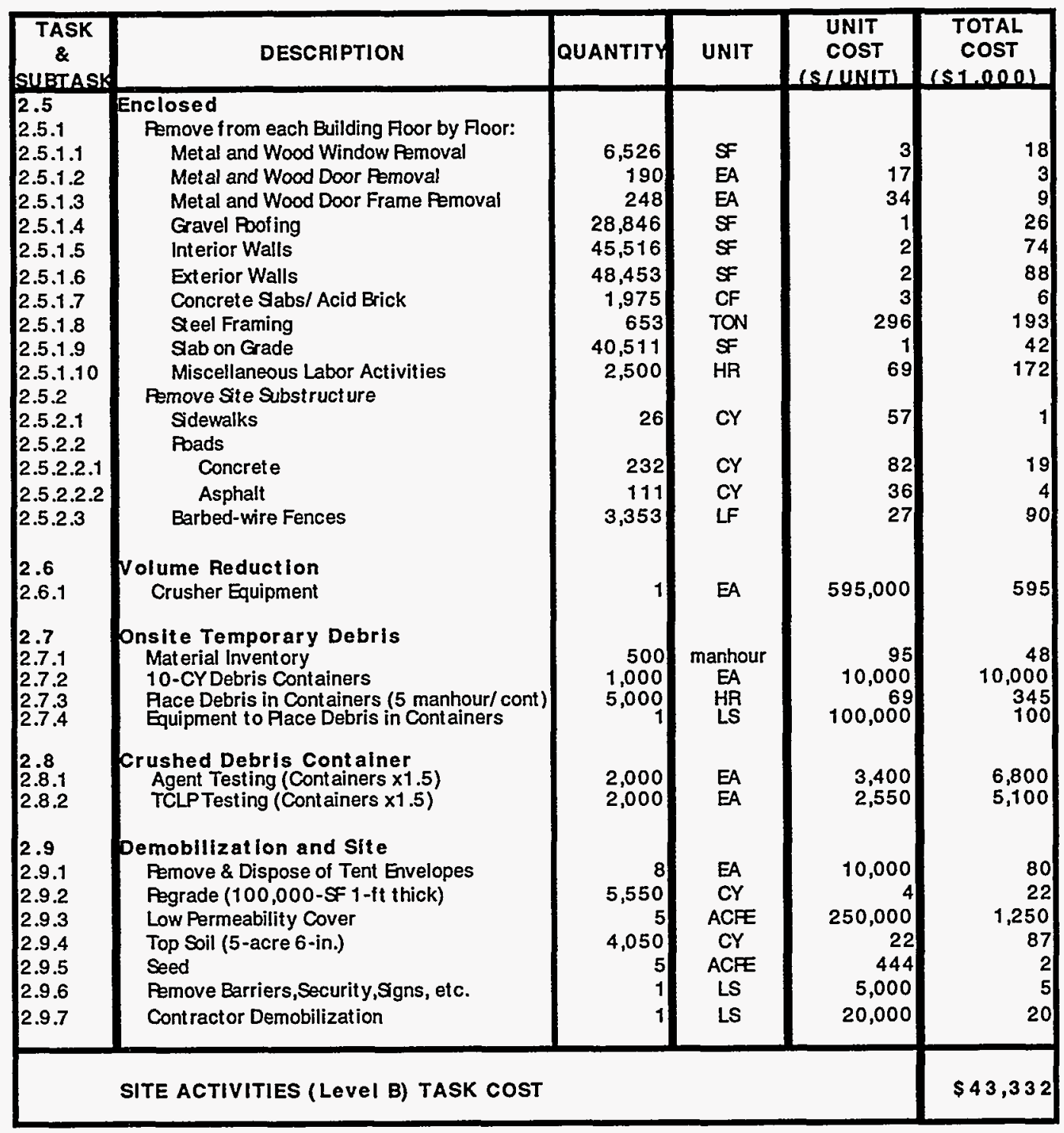


TABLE 7 (Cont.)

DETAIL (Continued)

\begin{tabular}{|c|c|c|c|c|c|}
\hline $\begin{array}{c}\text { TASK } \\
\& \\
\text { SURTASK }\end{array}$ & DESCRIPTION & QUANTITY & UNIT & $\begin{array}{c}\text { UNIT } \\
\text { COST } \\
\text { (S LUNIT) }\end{array}$ & $\begin{array}{c}\text { TOTAL } \\
\text { COST } \\
(\$ 1000)\end{array}$ \\
\hline $\begin{array}{l}\quad 3 \\
3.1 \\
3.1 .1 \\
3.1 .2 \\
3.2 \\
3.2 .1\end{array}$ & $\begin{array}{l}\text { OPERATION AND } \\
\text { Monthly ( } 30 \text { years) } \\
\text { Grass Mowing (2/month } 6 \text { months/ year) } \\
\text { Annual Inspection and Report } \\
\text { Yearly ( } 30 \text { years) } \\
\text { Annual Pepairs as needed }\end{array}$ & $\begin{array}{r}360 \\
30\end{array}$ & $\begin{array}{l}E A \\
E A \\
E A\end{array}$ & $\begin{array}{r}250 \\
1,000 \\
10,000\end{array}$ & $\begin{array}{r}90 \\
30 \\
300\end{array}$ \\
\hline & OPERATION AND MAINTENANCE TAS & DST & & & $\$ 420$ \\
\hline
\end{tabular}

Environmental controls will be required to prevent dust particulate escape from the controlled demolition activities at the site. Accordingly, an enclosure will be installed over each PPC building prior to commencing the enclosed demolition activities. Building E5625 will have the largest enclosure, because it will also house the crusher equipment and the air filtering system. The enclosure for Building E5625 will have to be at least $220-\mathrm{ft}$ wide by $500-\mathrm{ft}$ long and have an average height of $98 \mathrm{ft}$ to accommodate the building and the process equipment. This custommade, project-specific enclosure will have a minimum 110,000-square-foot footprint and an estimated design and construction cost of $\$ 9.35$ million. This enclosure will also accommodate all the buildings within the PPC except Building E5616. Building E5616 will have its own enclosure that will be at least $100-\mathrm{ft}$ long by $200-\mathrm{ft}$ wide and $35-\mathrm{ft}$ high. The cost of designing and constructing the enclosure for Building E5616 is estimated to be $\$ 1.02$ million. The unit prices for the design and construction of the envelopes are approximately $\$ 85$ and $\$ 51$ per square foot for each large and small envelope, respectively, due to the intricacies of the project and to the fact that the envelopes cannot be used again elsewhere.

A negative air-pressure system capable of handling four volume changes per hour and which includes an adequate air-filtering system will also be installed. The negative air-pressure system and dust-control system were sized for an anticipated maximum capacity of $1,110,000 \mathrm{cfm}$ when both enclosures are connected. This capacity includes a 50 percent redundancy. The large and small envelopes will have capacities of 10,417,000 cubic feet and 684,000 cubic feet, respectively.

Enclosed demolition activities will be conducted in a manner that is similar to the demolition activities described in Section 5.1.3, although they will vary according to the demolition method selected by the contractor and approved by APG. For the purposes of this cost estimate, the enclosed demolition activities will begin on a floor-by-floor basis by removing the interior metal-and-wood windows, doors and door frames, and the roof, if applicable, and then proceed to removing the interior walls. The exterior walls on each floor will be removed after the interior walls have been removed. PPC building structures will be razed, including the floor slabs. 
Structural foundations and any other below-grade structures (such as sumps or utility systems) will be left in place. Sumps and utility systems will be filled with concrete after the water has been pumped out. The water will be tested and, depending on the test results, disposed of appropriately. The cost to treat the sumps and utility systems is estimated to be between $\$ 50,000$ and $\$ 500,000$ and is included in the contingency budget. Site infrastructure will also be removed, including the sidewalks, concrete and asphalt roads, and barbed-wire fences.

The controlled demolition debris will be reduced in size by using a crusher capable of delivering crushed material that is approximately 1-1/2-in. in diameter. Crushed material will be temporarily stored on-site in 10- to 20-cubic-yard sealed containers that will be designed for that purpose. The origin of the material going into each sealed container will be inventoried. One thousand 10-cubic-yard sealed containers are estimated for this alternative.

A comprehensive program to test debris containers for agents and TCLP compounds will be implemented. Air and solid samples will be tested for agents, and solid samples will be tested using the TCLP. An average of 1.5 tests per sealed container will be conducted.

Demobilization and site restoration will include demobilization of contractor equipment and temporary facilities; removal of barriers, temporary security, and signs; regrading up to 150,000 square feet with an average 1-ft-thick layer of dirt; placing a low-permeability layer to reduce rainfall infiltration; topsoiling approximately 5 acres with an average 6-in.-thick layer of topsoil; and seeding the entire PPC area (approximately 5 acres).

Operation and maintenance activities are budgeted for 30 years from the date the field work is concluded. Operation and maintenance activities will include grass mowing, routine inspections, and minor surface repairs. The grass will be cut twice a month during the growing season, annual inspections will be conducted, and minor repairs will be performed as needed. A limited budget of $\$ 10,000$ per year was established for minor grass and erosion-control repairs.

Enveloping the entire PPC could also be achieved by designing and constructing a 300 -ft-wide by 600 -ft-long enclosure, at an estimated cost of $\$ 135$ per square foot. This total PPC envelope will cost at least $\$ 24$ million. In addition, the negative air-pressure system and dust-control devices will require a maximum capacity of $1,755,000 \mathrm{cfm}$, assuming a 50 percent redundancy. This total PPC envelope alternative was not included in the dismantling alternative cost estimate. However, implementation of the total PPC envelope alternative will add approximately $\$ 17$ million to the project, including adequate contingency provisions.

\subsection{Cost Estimates for Phase 2}

This section provides the considerations involved with estimating the costs associated with Phase 2. Phase 2 activities include the recycling, disposal, and possible treatment of the debris generated by Phase 1 activities. The debris will be either recycled or disposed of, and 
either option may involve prior treatment, as indicated by an evaluation of the test results from the debris testing program. Table 8 presents the estimated costs to implement the individual Phase 2 activities.

\subsubsection{Recycling}

Recycling material recovered from the demolition debris that has a street market value as high as $\$ 15$ per ton could provide a cost offset for other APG projects. Cost offsets will be realized if recycled materials, such as crushed concrete, are used in other APG projects, such as riprap protection. Recycled material from the PPC site will include structural steel and crushed demolition debris. Crushed demolition debris could be used for road subgrade or for many granular bases that APG currently purchases from outside vendors.

Recycled material will also provide another cost offset to the PPC project, because recycled material will not require disposal at a landfill. The avoided landfilling cost was not included in these cost estimates.

\subsubsection{Disposal}

Demolition debris could be disposed of at either an on-site or off-site demolition debris landfill, a commercial demolition debris landfill, or at a hazardous waste facility, depending on the results of the debris testing program.

\subsubsection{On-Site Landfill}

Landfilling at the APG landfill will require the transportation of the sealed containers to the on-site landfill site. For the purposes of this cost estimate, no APG landfilling fees will be required, only transportation costs: a 20 -mile hauling round trip was assumed.

\subsubsection{Commercial Nonhazardous Waste Landfill}

Landfilling at a commercial construction-debris landfill will require the transportation of sealed containers to a commercial site and the proper landfilling fees. For the purposes of this report, it was assumed that a commercial construction debris landfill is available within 20 miles of the site. 
TABLE 8 Cost Estimates for Recycling, Disposal, and Treatment

\begin{tabular}{|c|c|c|c|c|c|}
\hline $\begin{array}{c}\text { TASK } \\
\& \\
\text { SUBTASK } \\
\end{array}$ & DESCRIPTION & QUANTITY & UNIT & $\begin{array}{c}\text { UNIT } \\
\text { COST } \\
\text { (S/UNIT) } \\
\end{array}$ & $\begin{array}{c}\text { TOTAL } \\
\text { COST } \\
(\$ 1,000) \\
\end{array}$ \\
\hline 1.1 & $\begin{array}{l}\text { RECYCLING } \\
\text { Net Recycling Cost Offset }\end{array}$ & 10,004 & TON & 15 & 150 \\
\hline & RECYCLING ESTIMATED COST OFFSET & & & & $\$ 150$ \\
\hline
\end{tabular}

\begin{tabular}{|c|c|c|c|c|c|}
\hline \begin{tabular}{|c|} 
TASK \\
$\&$ \\
SUBTASK \\
\end{tabular} & DESCRIPTION & QUANTITY & UNIT & $\begin{array}{c}\text { UNIT } \\
\text { COST } \\
\text { (SIUNIT) }\end{array}$ & $\begin{array}{c}\text { TOTAL } \\
\text { COST } \\
(\$ 1,000) \\
\end{array}$ \\
\hline $\begin{array}{r}2 \\
2.1 \\
2.2\end{array}$ & $\begin{array}{l}\text { DEMOLITION DEBRIS DISPOSAL } \\
\text { Transportation To DD landfill w/in 20-mi } \\
\text { Dump Truck Hauling for each 10-CY Container } \\
\text { Disposal Gate Rate (Add } 25 \% \text { to Total PPC Vol) }\end{array}$ & $\begin{array}{r}20,000 \\
8,190\end{array}$ & $\begin{array}{c}\text { CY/MI } \\
\text { CY }\end{array}$ & $\begin{array}{r}1 \\
111\end{array}$ & $\begin{array}{r}10 \\
912\end{array}$ \\
\hline & DEMOLITION DEBRIS ESTIMATED COST & & & & $\$ 922$ \\
\hline
\end{tabular}

\begin{tabular}{|c|c|c|c|c|c|}
\hline \begin{tabular}{|c|} 
TASK \\
$\&$ \\
SUBTASK \\
\end{tabular} & DESCRIPTION & QUANTITY & UNIT & $\begin{array}{c}\text { UNIT } \\
\text { COST } \\
\text { (S/UNIT) } \\
\end{array}$ & $\begin{array}{c}\text { TOTAL } \\
\text { COST } \\
(\$ 1,000) \\
\end{array}$ \\
\hline $\begin{array}{l}3 \\
3.1 \\
3.2 \\
3.3\end{array}$ & $\begin{array}{l}\text { HAZARDOUS WASTE DISPOSAL } \\
\text { Transportation To HazWaste Landfill } \\
1200 \text { Mile Dump Truck Hauling } \\
\text { Army Escort (R/T per each 10-CY Container) } \\
\text { Disposal Gate Rate (Add } 25 \% \text { to Total PPC Vol) }\end{array}$ & $\begin{array}{r}1,200,000 \\
1,000 \\
8,190\end{array}$ & $\begin{array}{c}\text { CY/MI } \\
\text { Crew/RT } \\
\text { CY }\end{array}$ & $\begin{array}{r}3 \\
10,000 \\
223\end{array}$ & $\begin{array}{r}3,339 \\
10,000 \\
1,823\end{array}$ \\
\hline & HAZARDOUS WASTE DISPOSAL ESTIMATE & & & & $\$ 15,163$ \\
\hline
\end{tabular}

\begin{tabular}{|c|l|r|r|r|r|}
\hline $\begin{array}{c}\text { TASK } \\
\& \\
\text { SUBTASK }\end{array}$ & \multicolumn{1}{|c|}{ DESCRIPTION } & QUANTITY & UNIT & $\begin{array}{c}\text { UNIT } \\
\text { COST } \\
\text { (SIUNIT) }\end{array}$ & $\begin{array}{c}\text { TOTAL } \\
\text { COST } \\
(\$ 1,000)\end{array}$ \\
\hline 4 & $\begin{array}{l}\text { THERMAL TREATMENT } \\
\text { Thermal Treatment Process for PPC } \\
\text { Dismantled Material (25\% Contingency) }\end{array} .1$ & 12,506 & TON & 1,000 & 12,506 \\
\hline \multicolumn{2}{|l|}{ THERMAL TREATMENT ESTIMATED COST } & & & & \\
\hline
\end{tabular}




\subsubsection{Hazardous Waste Landfill}

Landfilling at a hazardous waste landfill will require the transportation of each of the sealed containers from APG to a certified hazardous waste landfill. For the purpose of this report, a private hazardous waste landfill at Emmele, Alabama, was used.

\subsubsection{Waste Treatment}

For the purposes of this evaluation, it was assumed that the thermal treatment, if needed, will be conducted at APG. The estimated total cost for thermal treating at $1000^{\circ}$ Fahrenheit for a minimum of 15 minutes is estimated to be $\$ 1,000$ per ton.

\subsection{Unit Cost and Quantity Estimates}

The basis for the estimated costs were the unit-cost and PPC building material quantity estimates prepared by ANL as described below.

The unit costs used for the development of this decommissioning alternatives evaluation are presented in Table 9. These unit costs were selected for the different activities from various sources, including the 1995 Environmental Restoration Unit Cost Book, published by Environmental Cost Handling Options and Solutions (ECHOS); the 1994 Means Building Construction Cost Data, 52nd Annual Edition; and from other sources within APG.

Summaries of the PPC building material quantity estimates are presented in Appendix A. The basis for the material quantity estimates were the Documentation and Quantification Reports prepared by ANL for each of the nine PPC buildings (Draugelis et al. 1995a,b; Smits et al. 1995; O'Reilly et al. 1995a,b; Muir-Ploense et al. 1995; Miller et al. 1995; Zellmer et al. 1995a,b). 


\begin{tabular}{|c|c|c|c|}
\hline DETAIL & UNITS & QUANTTIY & $\begin{array}{l}\text { UNADJUSTED } \\
\text { UNIT COST }\end{array}$ \\
\hline $\begin{array}{l}\text { Contingency } \\
\text { Consultant Rate } \\
\text { ANL Labor Rate } \\
\text { Asbestos Removal (Transite and Vinyl) } \\
\text { Metal and Wood Window Removal } \\
\text { Solid Metal and Wood Door Removal } \\
\text { Metal and Wood Door Frame Removal } \\
\text { Misc. Metal Removal } \\
\text { Gravel Roofing } \\
\text { Interior Walls (8-in.) } \\
\text { Exterior Walls (12-in.) } \\
\text { Concrete Floor Slabs/Acid Brick } \\
\text { Steel Beams and Columns } \\
\text { Slab on Grade (9-12 in.) } \\
\text { Miscellaneous Non-Hazardous Labor } \\
\text { Sidewalks (2,100-SF, 4-in. Thick) } \\
\text { Concrete Road (18,900-SF, 4-in. Thick) } \\
\text { Bituminous Road (20,896-SF, 4-in. Thick) } \\
\text { Temp. Silt Runoff Controls } \\
\text { Access Road (500 LF, Stone, 12-ft wide, 6-in. deep) } \\
\text { Repair 10-ft Barbed Wired Fence } \\
\text { New Outer 10-ft Barbed Wire Fence } \\
\text { Temp Silt Runoff Control } \\
\text { Equipment for Shredding } \\
\text { Recycling Program } \\
\text { On-Site Demolition Debris Disposal } \\
\text { Commercial Non-Haz Solid Bulk Waste } \\
\text { Commercial Haz Solid Waste } \\
\text { Regrade (150,000-SF 1-ft thick) } \\
\text { Top Soil (100,000-SF 6-in.) } \\
\text { Seed and Sodding } \\
\text { Remove Barriers, etc } \\
\text { Contractor(s) Demobilization } \\
\text { Grass Mowing } \\
\text { Annual Inspection and Report } \\
\text { Minor Annual Repairs } \\
\text { Alarm System } \\
\text { Enclosure Envelope per Floor } \\
\text { Dust Control } \\
\text { Negative Air System (4-Vol/hr) } \\
\text { 10-CY Containers (50\% Contingency) } \\
\text { Crusher Equipment } \\
\text { Low Permeability Cover } \\
\text { Container Agent Testing (2/Container) } \\
\text { Container TCLP Testing } \\
\text { Thermal Treatment Process (x25\%) } \\
\text { Dump Truck Hauling per Crushed Cont. } \\
\text { Army Escort } \\
\text { Aauling Crushed to Local DD Landfill } \\
\text { Remove 10-ft Barbed Wired Fence } \\
\text { Enclosure Envelope for Bldg E5625 } \\
\text { Enclosure Envelope for PPC } \\
\text { Annual Repairs }\end{array}$ & $\begin{array}{c}\text { Percentage } \\
\text { manhour } \\
\text { manhour } \\
\text { SF } \\
\text { SF } \\
\text { EA } \\
\text { EA } \\
\text { TON } \\
\text { SF } \\
\text { SF } \\
\text { SF } \\
\text { CF } \\
\text { TON } \\
\text { SF } \\
\text { HR } \\
\text { CY } \\
\text { CY } \\
\text { CY } \\
\text { LF } \\
\text { LF } \\
\text { LF } \\
\text { LF } \\
\text { LF } \\
\text { EA } \\
\text { TON } \\
\text { CY } \\
\text { CY } \\
\text { CY } \\
\text { CY } \\
\text { CY } \\
\text { ACRE } \\
\text { LS } \\
\text { LS } \\
\text { EA } \\
\text { EA } \\
\text { EA } \\
\text { EA } \\
\text { SF } \\
1,000 \text { CFM } \\
1,000 \text { CFM } \\
\text { EA } \\
\text { EA } \\
\text { ACRE } \\
\text { EA } \\
\text { EA } \\
\text { TON } \\
\text { CYIMI } \\
\text { Crew/RT } \\
\text { CY/MI } \\
\text { LF } \\
\text { SF } \\
\text { SF } \\
\text { EA } \\
\text { EA }\end{array}$ & $\begin{array}{r}7,140 \\
6,526 \\
190 \\
248 \\
8 \\
28,846 \\
45,516 \\
48,453 \\
1,975 \\
653 \\
40,511 \\
2,500 \\
26 \\
232 \\
111 \\
500 \\
100 \\
100 \\
1,890 \\
1,890 \\
1 \\
10,004 \\
8,190 \\
8,190 \\
8,190 \\
5,550 \\
1,850 \\
5 \\
1 \\
1 \\
1 \\
360 \\
30 \\
30 \\
30 \\
1 \\
1,200,000 \\
1,000 \\
20,000 \\
3,353 \\
110,000 \\
180,000 \\
20,000 \\
30\end{array}$ & $\begin{array}{r}15.00 \\
95.00 \\
95.00 \\
1.87 \\
1.62 \\
10.12 \\
20.27 \\
816.14 \\
0.53 \\
0.96 \\
1.07 \\
1.85 \\
174.00 \\
0.61 \\
40.53 \\
33.39 \\
48.09 \\
21.37 \\
70.80 \\
70.80 \\
26.82 \\
29.18 \\
1.29 \\
250,000.00 \\
15.00 \\
54.43 \\
111.31 \\
222.62 \\
2.29 \\
21.56 \\
385.87 \\
5,000.00 \\
20,000.00 \\
250.00 \\
1,000.00 \\
5,000.00 \\
35,000.00 \\
15.00 \\
1,500.00 \\
2,500.00 \\
10,000.00 \\
350,000.00 \\
250,000.00 \\
2,000.00 \\
1,500.00 \\
1,000.00 \\
2.78 \\
10,000.00 \\
0.50 \\
26.82 \\
50.00 \\
80.00 \\
30.00 \\
10,000.00\end{array}$ \\
\hline
\end{tabular}




\section{References}

Anderson, R.W., and T.C. Kvitek, 1995, Interim Report: Historical Survey, Building E5625 Complex (Pilot Plant), Aberdeen Proving Ground, report prepared for Directorate of Safety, Health and Environment, Aberdeen Proving Ground, Maryland.

Argonne National Laboratory, 1995, Draft Environmental Assessment for Demolition of the Pilot Plant Complex, Aberdeen Proving Ground, Environmental Assessment Division, Argonne, Ill.

Brubaker, K.L., 1994, Initial Building Investigations at Aberdeen Proving Ground, Maryland: Objectives and Methodology, ANL/ESD/TM-61, Argonne National Laboratory, Argonne, Ill.

Brubaker, K.L., et al., 1995a, X-Ray Fluorescence Investigation of Surface Lead in the Pilot Plant Complex, Aberdeen Proving Ground, Maryland, ANL/ESD/TM-113, Argonne National Laboratory, Argonne, Ill.

Brubaker, K.L., et al., 1995b, X-Ray Fluorescence Investigation of Heavy Metal Contamination on Metal Surfaces in the Pilot Plant Complex, Aberdeen Proving Ground, Maryland, ANL/ESD/TM-118, Argonne National Laboratory, Argonne, Ill.

Carpenter, T.J., and T.E. Hill, 1988, Methods for Demolition of Building E5625, Battelle Columbus Division, Columbus, Ohio.

Draugelis, A.K., et al., 1995a, Building E5616 Documentation and Quantification, Pilot Plant Complex, Aberdeen Proving Ground, Maryland, ANL/ESD/TM-123, Argonne National Laboratory, Argonne, Ill.

Draugelis, A.K., et al., 1995b, Building E5625 Documentation and Quantification, Pilot Plant Complex, Aberdeen Proving Ground, Maryland, ANL/ESD/TM-127, Argonne National Laboratory, Argonne, Ill.

McGinnis, L.D., et al., 19.94, Environmental Geophysics of the Pilot Plant on the West Branch of Canal Creek, Aberdeen Proving Ground, Maryland, ANL/ESD/TM-74, Argonne National Laboratory, Argonne, Ill.

Miller, G.A., et al., 1995, Building E5627 Documentation and Quantification, Pilot Plant Complex, Aberdeen Proving Ground, Maryland, ANL/ESD/TM-130, Argonne National Laboratory, Argonne, Ill.

Muir-Ploense, K., et al., 1995, Building E5626 Documentation and Quantification, Pilot Plant Complex, Aberdeen Proving Ground, Maryland, ANL/ESD/TM-131, Argonne National Laboratory, Argonne, Ill. 
Nemeth, G., 1989, RCRA Facility Assessment Report, Edgewood Area, Aberdeen Proving Ground, Maryland, Waste Disposal Engineering Division, U.S. Army Environmental Hygiene Agency, Aberdeen Proving Ground, Md.

O'Reilly, D.P., et al., 1995a, Building E5618 Documentation and Quantification, Pilot Plant Complex, Aberdeen Proving Ground, Maryland, ANL/ESD/TM-125, Argonne National Laboratory, Argonne, Ill.

O'Reilly, D.P., et al., 1995b, Building E5621 Documentation and Quantification, Pilot Plant Complex, Aberdeen Proving Ground, Maryland, ANL/ESD/TM-126, Argonne National Laboratory, Argonne, Ill.

Schneider, J.F., et al., 1995a, Air Monitoring for Volatile Organic Compounds at the Pilot Plant Complex, Aberdeen Proving Ground, Maryland, ANL/ESD/TM-94, Argonne National Laboratory, Argonne, Ill.

Schneider, J.F., et al., 1995b, Monitoring for PCBs at the Pilot Plant Complex, Aberdeen Proving Ground, ANL/ESD/TM-116, Argonne National Laboratory, Argonne, Ill.

Smits, M.P., et al., 1995, Building E5617 Documentation and Quantification, Pilot Plant Complex, Aberdeen Proving Ground, Maryland, ANL/ESD/TM-124, Argonne National Laboratory, Argonne, Ill.

Tomczyk, N.A., et al., 1995, Survey for Glycolates and Lewisite Degradation Products in Building E5625, Aberdeen Proving. Ground, Maryland, ANL/ESD/TM-91, Argonne National Laboratory, Argonne, Ill.

Yon, R.L., 1988, Building E5625 Usage Survey/Historical Records Search, U.S. Chemical Research, Development and Engineering Center, Aberdeen Proving Ground, Md.

Zellmer, S.D., et al., 1995a, Building E5632 Documentation and Quantification, Pilot Plant Complex, Aberdeen Proving Ground, Maryland, ANL/ESD/TM-129, Argonne National Laboratory, Argonne, Ill.

Zellmer, S.D., et al., 1995b, Building E5633 Documentation and Quantification, Pilot Plant Complex, Aberdeen Proving Ground, Maryland, ANL/ESD/TM-128, Argonne National Laboratory, Argonne, Ill.

1994 Means Building Construction Cost Data, 52nd Annual Edition, Kingston, Mass.

1995 Environmental Restoration Unit Cost Book, Environmental Cost Handling Options and Solutions (ECHOS), Los Angeles, Calif. 
Appendix:

Quantity Estimates for the Pilot Plant Complex 


\section{Appendix: Quantity Estimates for the Pilot Plant Complex}

\section{Introduction}

This appendix summarizes the Pilot Plant Complex (PPC) building material quantity estimates reported in the Documentation and Quantification Reports prepared by Argonne National Laboratory (ANL) for each of the nine PPC buildings. The PPC is located in the Edgewood Area (EA) at the Aberdeen Proving Ground (APG). APG is located on Maryland's Chesapeake Bay in Harford and Baltimore Counties (see Figure A.1). A site plan of the PPC is shown in Figure A.2. 


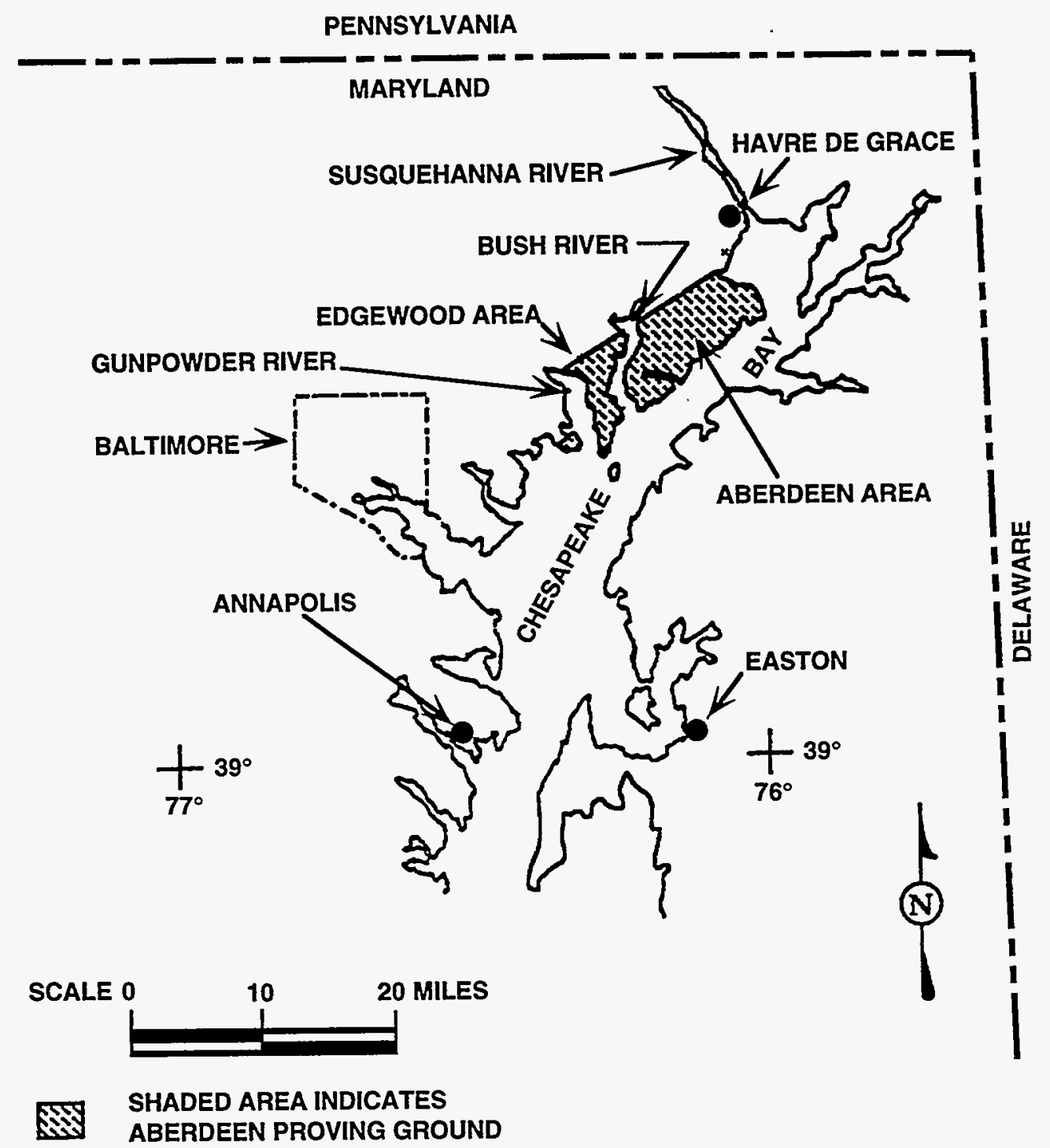

FIGURE A.1 Aberdeen Proving Ground Location Map 


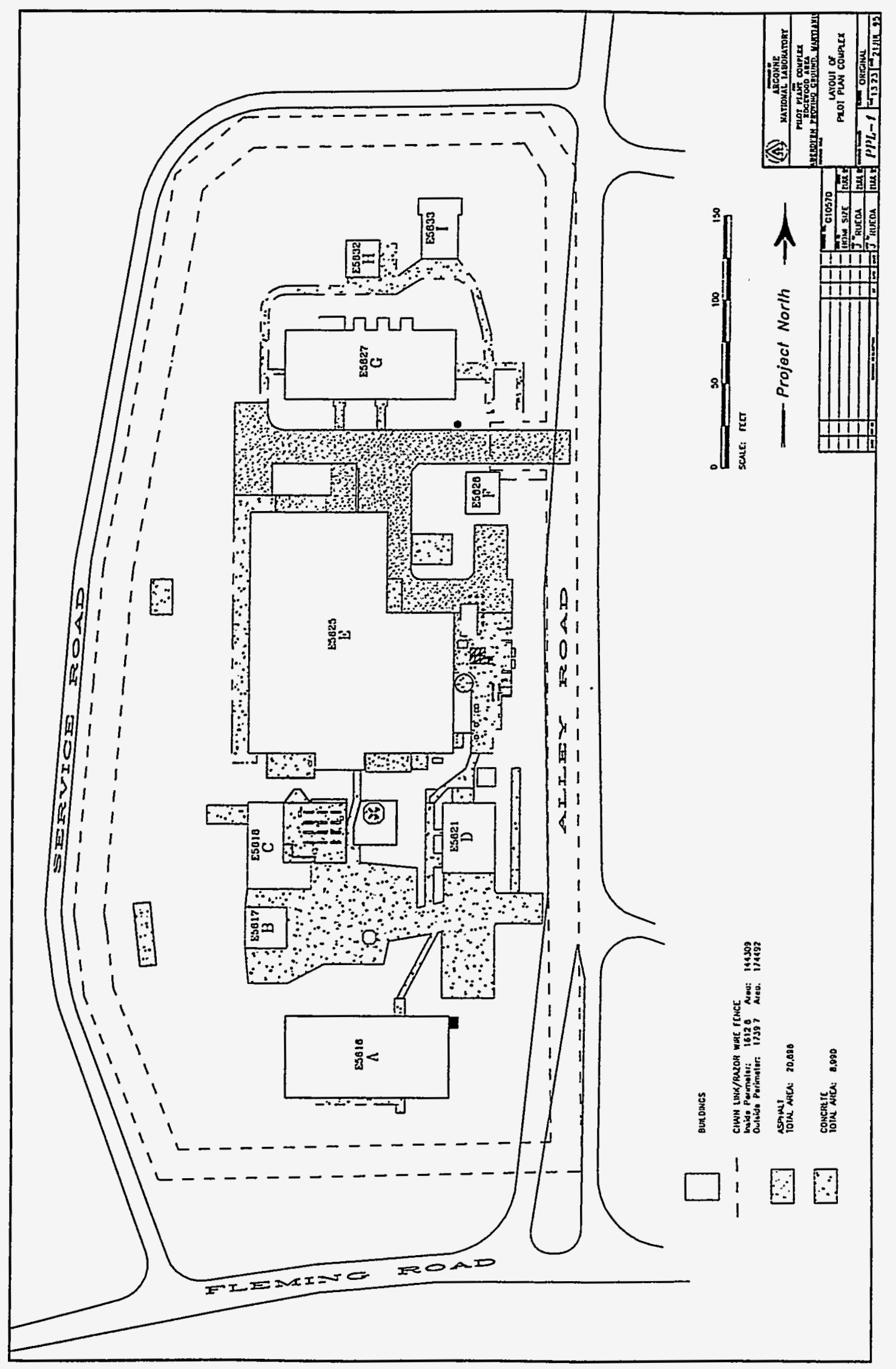

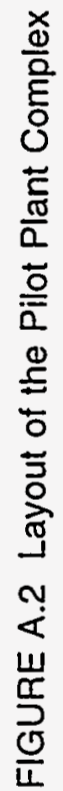




\section{Quantity Estimates}

The following is a summary of the PPC building material quantity estimates prepared from the Documentation and Quantification Reports prepared by ANL for each of the nine PPC buildings (Draugelis et al. 1995a,b; Smits et al. 1995; O'Reilly et al. 1995a,b; Muir-Ploense et al. 1995; Miller et al. 1995; Zellmer et al. 1995a,b).

The material quantity estimates were prepared on a volume and weight basis for each PPC building. The volume estimates are presented in Tables A.1 through A.4 as in situ rubble and crushed material estimates. In-situ material quantity estimates for each of the nine buildings at the PPC are presented in Tables A.5 through A.12. The rubble and crushed factors as well as the unit weight for the materials found in the PPC are also presented in Table A.13. The basis for these material quantity estimates were the floor plans prepared for each of the nine buildings at the PPC, as presented in the Documentation and Quantification Reports. These floor plans are presented in Figures A.3 through A.15.

A quantity survey to assess the accuracy of the material quantity estimates prepared by ANL was commissioned to Tadjer, Cohen, Edelson and Associates, a consulting structural engineers firm in Silver Spring, Maryland. A May 1995 draft of their report indicates that the measurements and estimates prepared by ANL were sufficiently accurate for the purpose of this evaluation (Khanna 1995). 
TABLE A.1 Pilot Plant Complex Structural Survey Summary

\begin{tabular}{|c|c|c|c|c|c|c|c|c|}
\hline \multirow{2}{*}{ MATERIAL } & \multicolumn{7}{|c|}{ BY VOLUME } & \multicolumn{2}{c|}{ BY WEIGHT } \\
\cline { 2 - 8 } & \multicolumn{2}{|c|}{ In Situ } & \multicolumn{2}{|c|}{ As Rubble } & \multicolumn{2}{c|}{ Crushed } & \multicolumn{2}{c|}{} \\
\cline { 2 - 9 } & CY & $\%$ & CY & $\%$ & CY & $\%$ & Tons & $\%$ \\
\hline Clay Tile & 957 & 18 & 1,914 & 20 & 1,244 & 19 & 1,744 & 17 \\
Brick & 238 & 5 & 357 & 4 & 309 & 5 & 385 & 4 \\
Cinder Block & 433 & 8 & 866 & 9 & 476 & 7 & 473 & 5 \\
Plexiglas & 55 & 1 & 88 & 1 & 71 & 1 & 96 & 1 \\
Metal & 48 & 1 & 115 & 1 & 58 & 1 & 95 & 1 \\
Wood & 4 & 0 & 7 & 0 & 5 & 0 & 4 & 0 \\
Acid Brick & 123 & 2 & 184 & 2 & 159 & 2 & 232 & 2 \\
Tarmac & 71 & 1 & 121 & 1 & 114 & 2 & 87 & 1 \\
Structural Steel & 196 & 4 & 489 & 5 & 294 & 4 & 555 & 5 \\
Reinforced Concrete & 1,835 & 35 & 3,670 & 38 & 2,386 & 36 & 3,964 & 38 \\
Slab Concrete & 700 & 13 & 702 & 7 & 701 & 11 & 1,512 & 15 \\
Concrete Pavement & 387 & 7 & 774 & 8 & 503 & 8 & 836 & 8 \\
Asphalt Pavement & 111 & 2 & 222 & 2 & 144 & 2 & 217 & 2 \\
Miscellaneous & 77 & 1 & 153 & 2 & 100 & 2 & 134 & 1 \\
\hline TOtAL & 5,234 & 100 & 9,662 & 100 & 6,564 & 100 & 10,335 & 100 \\
\hline
\end{tabular}

TABLE A.2 Pilot Plant Complex Material Weight Summary

\begin{tabular}{|c|c|c|c|c|c|c|c|c|c|c|c|}
\hline \multirow{2}{*}{ MATERIAL } & \multicolumn{11}{|c|}{ MATEAIAL WEIGHT (TONS) } \\
\hline & $E 5616$ & $E 5617$ & $E 5618$ & E5621 & E5625 & $E 5626$ & $E 5627$ & $E 5632$ & E5633 & GAONDS & TOTAL \\
\hline Clay Tile & 185 & 57 & 82 & 61 & 1,037 & 0 & 297 & 0 & 25 & 0 & 1,744 \\
\hline Brick & 0 & 0 & 0 & 0 & 384 & 0 & 2 & 0 & 0 & 0 & 385 \\
\hline Cinder Block & 30 & 0 & 6 & 18 & 371 & 23 & 9 & 16 & 0 & 0 & 473 \\
\hline Plexiglas & 0 & 0 & 0 & 0 & 96 & 0 & 0 & 0 & 0 & 0 & 96 \\
\hline Metal & 8 & 1 & 3 & 3 & 69 & 1 & 9 & 0 & 0 & 0 & 95 \\
\hline Wood & 0 & 0 & 0 & 0 & 4 & 0 & 0 & 0 & 0 & 0 & 4 \\
\hline Acid Brick & 0 & 0 & 0 & 0 & 232 & 0 & 0 & 0 & 0 & 0 & 232 \\
\hline Tarmac & 18 & 2 & 2 & 5 & 58 & 2 & 0 & 0 & 0 & 0 & 87 \\
\hline Structural Steel & 30 & 7 & 10 & 11 & 462 & 0 & 32 & 0 & 4 & 0 & 555 \\
\hline Reinforced Concrete & 370 & 41 & 91 & 117 & 2,936 & 38 & 309 & 19 & 42 & 0 & 3,964 \\
\hline Slab Concrete & 46 & 32 & 24 & 23 & 1,100 & 120 & 55 & 96 & 16 & 0 & 1,512 \\
\hline Concrete Pavement & 0 & 0 & 0 & 0 & 0 & 0 & 0 & 0 & 0 & 836 & 836 \\
\hline Asphalt Pavement & 0 & 0 & 0 & 0 & 0 & 0 & 0 & 0 & 0 & 217 & 217 \\
\hline Miscellaneous & 6 & 0 & 0 & 0 & 9 & 12 & 76 & 1 & 1 & 28 & 134 \\
\hline TOTAL & 692 & 141 & 219 & 238 & 6,758 & 196 & 790 & 132 & 88 & 1,081 & 10,335 \\
\hline
\end{tabular}


TABLE A.3 Building E5616 Structural Survey Summary

\begin{tabular}{|c|c|c|c|c|c|c|c|c|}
\hline \multirow{2}{*}{ MATERIAL } & \multicolumn{7}{|c|}{ BY VOLUME } & \multicolumn{2}{c|}{ BY WEIGHT } \\
\cline { 2 - 8 } & \multicolumn{2}{|c|}{ In Situ } & \multicolumn{2}{|c|}{ As Rubble } & \multicolumn{2}{c|}{ Crushed } & \multicolumn{2}{c|}{} \\
\cline { 2 - 8 } & CY & $\%$ & CY & $\%$ & CY & $\%$ & Tons & $\%$ \\
\hline Clay Tile & 101 & 29 & 202 & 29 & 132 & 29 & 185 & 27 \\
Brick & 0 & 0 & 0 & 0 & 0 & 0 & 0 & 0 \\
Cinder Block & 28 & 8 & 56 & 8 & 31 & 7 & 30 & 4 \\
Plexiglas & 0 & 0 & 0 & 0 & 0 & 0 & 0 & 0 \\
Metal & 4 & 1 & 10 & 1 & 5 & 1 & 8 & 1 \\
Wood & 0 & 0 & 0 & 0 & 0 & 0 & 0 & 0 \\
Acid Brick & 0 & 0 & 0 & 0 & 0 & 0 & 0 & 0 \\
Tarmac & 15 & 4 & 25 & 4 & 24 & 5 & 18 & 3 \\
Structural Steel & 11 & 3 & 26 & 4 & 16 & 3 & 30 & 4 \\
Reinforced Concrete & 171 & 48 & 343 & 49 & 223 & 49 & 370 & 53 \\
Slab Concrete & 21 & 6 & 23 & 3 & 22 & 5 & 46 & 7 \\
Concrete Pavement & 0 & 0 & 0 & 0 & 0 & 0 & 0 & 0 \\
Asphalt Pavement & 0 & 0 & 0 & 0 & 0 & 0 & 0 & 0 \\
Miscellaneous & 4 & 1 & 8 & 1 & 5 & 1 & 6 & 1 \\
\hline TOTAL & 355 & 100 & 693 & 100 & 457 & 100 & 692 & 100 \\
\hline
\end{tabular}

TABLE A.4 Building E5617 Structural Survey Summary

\begin{tabular}{|c|c|c|c|c|c|c|c|c|}
\hline \multirow{2}{*}{ MATERIAL } & \multicolumn{7}{|c|}{ BY VOLUME } & \multicolumn{2}{c|}{ BY WEIGHT } \\
\cline { 2 - 8 } & \multicolumn{2}{|c|}{ In Situ } & \multicolumn{2}{|c|}{ As Rubble } & \multicolumn{2}{c|}{ Crushed } & \multicolumn{2}{c|}{} \\
\cline { 2 - 8 } & CY & $\%$ & CY & $\%$ & CY & $\%$ & Tons & $\%$ \\
\hline Clay Tile & 32 & 45 & 63 & 49 & 41 & 46 & 57 & 41 \\
Brick & 0 & 0 & 0 & 0 & 0 & 0 & 0 & 0 \\
Cinder Block & 0 & 0 & 0 & 0 & 0 & 0 & 0 & 0 \\
Plexiglas & 0 & 0 & 0 & 0 & 0 & 0 & 0 & 0 \\
Metal & 1 & 1 & 1 & 1 & 1 & 1 & 1 & 1 \\
Wood & 0 & 0 & 0 & 0 & 0 & 0 & 0 & 0 \\
Acid Brick & 0 & 0 & 0 & 0 & 0 & 0 & 0 & 0 \\
Tarmac & 1 & 2 & 2 & 2 & 2 & 2 & 2 & 1 \\
Structural Steel & 2 & 3 & 6 & 5 & 4 & 4 & 7 & 5 \\
Reinforced Concrete & 19 & 27 & 38 & 30 & 25 & 28 & 41 & 29 \\
Slab Concrete & 15 & 21 & 17 & 13 & 16 & 18 & 32 & 23 \\
Concrete Pavement & 0 & 0 & 0 & 0 & 0 & 0 & 0 & 0 \\
Asphalt Pavement & 0 & 0 & 0 & 0 & 0 & 0 & 0 & 0 \\
Miscellaneous & 0 & 0 & 1 & 1 & 0 & 0 & 0 & 0 \\
\hline TOTAL & 70 & 100 & 128 & 100 & 89 & 100 & 141 & 100 \\
\hline
\end{tabular}


TABLE A.5 Building E5618 Structural Survey Summary

\begin{tabular}{|c|c|c|c|c|c|c|c|c|}
\hline \multirow{2}{*}{ MATERIAL } & \multicolumn{7}{|c|}{ BY VOLUME } & \multicolumn{2}{c|}{ BY WEIGHT } \\
\cline { 2 - 8 } & \multicolumn{2}{|c|}{ In Situ } & \multicolumn{2}{|c|}{ As Rubble } & \multicolumn{2}{c|}{ Crushed } & \multicolumn{2}{c|}{} \\
\cline { 2 - 8 } & CY & $\%$ & CY & $\%$ & CY & $\%$ & Tons & $\%$ \\
\hline Clay Tile & 45 & 40 & 90 & 42 & 58 & 41 & 82 & 37 \\
Brick & 0 & 0 & 0 & 0 & 0 & 0 & 0 & 0 \\
Cinder Block & 6 & 5 & 11 & 5 & 6 & 4 & 6 & 3 \\
Plexiglas & 0 & 0 & 0 & 0 & 0 & 0 & 0 & 0 \\
Metal & 2 & 1 & 4 & 2 & 2 & 1 & 3 & 1 \\
Wood & 0 & 0 & 0 & 0 & 0 & 0 & 0 & 0 \\
Acid Brick & 0 & 0 & 0 & 0 & 0 & 0 & 0 & 0 \\
Tarmac & 2 & 2 & 3 & 2 & 3 & 2 & 2 & 1 \\
Structural Steel & 3 & 3 & 8 & 4 & 5 & 4 & 10 & 4 \\
Reinforced Concrete & 42 & 38 & 85 & 39 & 55 & 39 & 91 & 42 \\
Slab Concrete & 11 & 10 & 13 & 6 & 13 & 9 & 24 & 11 \\
Concrete Pavement & 0 & 0 & 0 & 0 & 0 & 0 & 0 & 0 \\
Asphalt Pavement & 0 & 0 & 0 & 0 & 0 & 0 & 0 & 0 \\
Miscellaneous & 0 & 0 & 0 & 0 & 0 & 0 & 0 & 0 \\
\hline TOTAL & 111 & 100 & 214 & 100 & 142 & 100 & 219 & 100 \\
\hline
\end{tabular}

TABLE A.6 Building E5621 Structural Survey Summary

\begin{tabular}{|c|c|c|c|c|c|c|c|c|}
\hline \multirow{2}{*}{ MATERIAL } & \multicolumn{7}{|c|}{ BY VOLUME } & \multicolumn{2}{c|}{ BY WEIGHT } \\
\cline { 2 - 8 } & \multicolumn{2}{|c|}{ In Situ } & \multicolumn{2}{|c|}{ As Rubble } & \multicolumn{2}{c|}{ Crushed } & \multicolumn{2}{c|}{} \\
\cline { 2 - 9 } & CY & $\%$ & CY & $\%$ & CY & $\%$ & Tons & $\%$ \\
\hline Clay Tile & 34 & 27 & 67 & 28 & 44 & 28 & 61 & 26 \\
Brick & 0 & 0 & 0 & 0 & 0 & 0 & 0 & 0 \\
Cinder Block & 17 & 13 & 33 & 14 & 18 & 12 & 18 & 8 \\
Plexiglas & 0 & 0 & 0 & 0 & 0 & 0 & 0 & 0 \\
Metal & 2 & 1 & 4 & 2 & 2 & 1 & 3 & 1 \\
Wood & 0 & 0 & 0 & 0 & 0 & 0 & 0 & 0 \\
Acid Brick & 0 & 0 & 0 & 0 & 0 & 0 & 0 & 0 \\
Tarmac & 4 & 3 & 7 & 3 & 6 & 4 & 5 & 2 \\
Structural Steel & 4 & 3 & 10 & 4 & 6 & 4 & 11 & 5 \\
Reinforced Concrete & 54 & 43 & 108 & 45 & 70 & 44 & 117 & 49 \\
Slab Concrete & 11 & 9 & 13 & 5 & 12 & 8 & 23 & 10 \\
Concrete Pavement & 0 & 0 & 0 & 0 & 0 & 0 & 0 & 0 \\
Asphalt Pavement & 0 & 0 & 0 & 0 & 0 & 0 & 0 & 0 \\
Miscellaneous & 0 & 0 & 0 & 0 & 0 & 0 & 0 & 0 \\
\hline TOTAL & 125 & 100 & 242 & 100 & 158 & 100 & 238 & 100 \\
\hline
\end{tabular}


TABLE A.7 Building E5625 Structural Survey Summary

\begin{tabular}{|c|c|c|c|c|c|c|c|c|}
\hline \multirow{2}{*}{ MATERIAL } & \multicolumn{7}{|c|}{ BY VOLUME } & \multicolumn{2}{c|}{ BY WEIGHT } \\
\cline { 2 - 8 } & \multicolumn{2}{|c|}{ In Situ } & \multicolumn{2}{c|}{ As Rubble } & \multicolumn{2}{c|}{ Crushed } & \\
\cline { 2 - 8 } & CY & $\%$ & CY & $\%$ & CY & $\%$ & Tons & $\%$ \\
\hline Clay Tile & 569 & 17 & 1,138 & 18 & 740 & 17 & 1,037 & 15 \\
Brick & 237 & 7 & 355 & 6 & 308 & 7 & 384 & 6 \\
Cinder Block & 339 & 10 & 678 & 11 & 373 & 9 & 371 & 5 \\
Plexiglas & 55 & 2 & 88 & 1 & 71 & 2 & 96 & 1 \\
Metal & 34 & 1 & 83 & 1 & 41 & 1 & 69 & 1 \\
Wood & 4 & 0 & 7 & 0 & 5 & 0 & 4 & 0 \\
Acid Brick & 123 & 4 & 184 & 3 & 159 & 4 & 232 & 3 \\
Tarmac & 47 & 1 & 81 & 1 & 76 & 2 & 58 & 1 \\
Structural Steel & 163 & 5 & 407 & 7 & 244 & 6 & 462 & 7 \\
Reinforced Concrete & 1,359 & 39 & 2,719 & 43 & 1,767 & 41 & 2,936 & 43 \\
Slab Concrete & 509 & 15 & 511 & 8 & 511 & 12 & 1,100 & 16 \\
Concrete Pavement & 0 & 0 & 0 & 0 & 0 & 0 & 0 & 0 \\
Asphalt Pavement & 0 & 0 & 0 & 0 & 0 & 0 & 0 & 0 \\
Miscellaneous & 5 & 0 & 10 & 0 & 7 & 0 & 9 & 0 \\
\hline TOTAL & 3,445 & 100 & 6,261 & 100 & 4,302 & 100 & 6,758 & 100 \\
\hline
\end{tabular}

TABLE A.8 Building E5626 Structural Survey Summary

\begin{tabular}{|c|c|c|c|c|c|c|c|c|}
\hline \multirow{2}{*}{ MATERIAL } & \multicolumn{7}{|c|}{ BY VOLUME } & \multicolumn{2}{c|}{ BY WEIGHT } \\
\cline { 2 - 8 } & \multicolumn{2}{|c|}{ In Situ } & \multicolumn{2}{|c|}{ As Rubble } & \multicolumn{2}{c|}{ Crushed } & \multicolumn{2}{c|}{} \\
\cline { 2 - 8 } & CY & $\%$ & CY & $\%$ & CY & $\%$ & Tons & $\%$ \\
\hline Clay Tile & 0 & 0 & 0 & 0 & 0 & 0 & 0 & 0 \\
Brick & 0 & 0 & 0 & 0 & 0 & 0 & 0 & 0 \\
Cinder Block & 21 & 20 & 42 & 27 & 23 & 20 & 23 & 12 \\
Plexiglas & 0 & 0 & 0 & 0 & 0 & 0 & 0 & 0 \\
Metal & 1 & 1 & 1 & 1 & 1 & 1 & 1 & 1 \\
Wood & 0 & 0 & 0 & 0 & 0 & 0 & 0 & 0 \\
Acid Brick & 0 & 0 & 0 & 0 & 0 & 0 & 0 & 0 \\
Tarmac & 2 & 1 & 3 & 2 & 2 & 2 & 2 & 1 \\
Structural Steel & 0 & 0 & 0 & 0 & 0 & 0 & 0 & 0 \\
Reinforced Concrete & 18 & 17 & 35 & 23 & 23 & 20 & 38 & 20 \\
Slab Concrete & 56 & 54 & 58 & 37 & 57 & 49 & 120 & 61 \\
Concrete Pavement & 0 & 0 & 0 & 0 & 0 & 0 & 0 & 0 \\
Asphalt Pavement & 0 & 0 & 0 & 0 & 0 & 0 & 0 & 0 \\
Miscellaneous & 7 & 7 & 14 & 9 & 9 & 8 & 12 & 6 \\
\hline TOTAL & 104 & 100 & 154 & 100 & 116 & 100 & 196 & 100 \\
\hline
\end{tabular}


TABLE A.9 Building E5627 Structural Survey Summary

\begin{tabular}{|c|c|c|c|c|c|c|c|c|}
\hline \multirow{2}{*}{ MATERIAL } & \multicolumn{7}{|c|}{ BY VOLUME } & \multicolumn{2}{c|}{ BY WEIGHT } \\
\cline { 2 - 8 } & \multicolumn{2}{|c|}{ In Situ } & \multicolumn{2}{|c|}{ As Rubble } & \multicolumn{2}{c|}{ Crushed } & \multicolumn{2}{c|}{} \\
\cline { 2 - 9 } & CY & $\%$ & CY & $\%$ & CY & $\%$ & Tons & $\%$ \\
\hline Clay Tile & 163 & 40 & 326 & 41 & 212 & 41 & 297 & 38 \\
Brick & 1 & 0 & 2 & 0 & 1 & 0 & 2 & 0 \\
Cinder Block & 9 & 2 & 17 & 2 & 9 & 2 & 9 & 1 \\
Plexiglas & 0 & 0 & 0 & 0 & 0 & 0 & 0 & 0 \\
Metal & 5 & 1 & 12 & 2 & 6 & 1 & 9 & 1 \\
Wood & 0 & 0 & 0 & 0 & 0 & 0 & 0 & 0 \\
Acid Brick & 0 & 0 & 0 & 0 & 0 & 0 & 0 & 0 \\
Tarmac & 0 & 0 & 0 & 0 & 0 & 0 & 0 & 0 \\
Structural Steel & 11 & 3 & 29 & 4 & 17 & 3 & 32 & 4 \\
Reinforced Concrete & 143 & 35 & 286 & 36 & 186 & 36 & 309 & 39 \\
Slab Concrete & 25 & 6 & 27 & 3 & 27 & 5 & 55 & 7 \\
Concrete Pavement & 0 & 0 & 0 & 0 & 0 & 0 & 0 & 0 \\
Asphalt Pavement & 0 & 0 & 0 & 0 & 0 & 0 & 0 & 0 \\
Miscellaneous & 48 & 12 & 95 & 12 & 62 & 12 & 76 & 10 \\
\hline TOTAL & 405 & 100 & 794 & 100 & 520 & 100 & 790 & 100 \\
\hline
\end{tabular}

TABLE A.10 Building E5632 Structural Survey Summary

\begin{tabular}{|c|c|c|c|c|c|c|c|c|}
\hline \multirow{2}{*}{ MATERIAL } & \multicolumn{7}{|c|}{ BY VOLUME } & \multicolumn{2}{c|}{ BY WEIGHT } \\
\cline { 2 - 8 } & \multicolumn{2}{|c|}{ In Situ } & \multicolumn{2}{|c|}{ As Rubble } & \multicolumn{2}{c|}{ Crushed } & \multicolumn{2}{c|}{} \\
\cline { 2 - 8 } & CY & $\%$ & CY & $\%$ & CY & $\%$ & Tons & $\%$ \\
\hline Clay Tile & 0 & 0 & 0 & 0 & 0 & 0 & 0 & 0 \\
Brick & 0 & 0 & 0 & 0 & 0 & 0 & 0 & 0 \\
Cinder Block & 14 & 21 & 28 & 30 & 16 & 21 & 16 & 12 \\
Plexiglas & 0 & 0 & 0 & 0 & 0 & 0 & 0 & 0 \\
Metal & 0 & 0 & 0 & 0 & 0 & 0 & 0 & 0 \\
Wood & 0 & 0 & 0 & 0 & 0 & 0 & 0 & 0 \\
Acid Brick & 0 & 0 & 0 & 0 & 0 & 0 & 0 & 0 \\
Tarmac & 0 & 0 & 0 & 0 & 0 & 0 & 0 & 0 \\
Structural Steel & 0 & 0 & 0 & 0 & 0 & 0 & 0 & 0 \\
Reinforced Concrete & 9 & 13 & 18 & 19 & 11 & 15 & 19 & 14 \\
Slab Concrete & 44 & 65 & 46 & 49 & 46 & 62 & 96 & 73 \\
Concrete Pavement & 0 & 0 & 0 & 0 & 0 & 0 & 0 & 0 \\
Asphalt Pavement & 0 & 0 & 0 & 0 & 0 & 0 & 0 & 0 \\
Miscellaneous & 1 & 2 & 2 & 3 & 2 & 2 & 1 & 1 \\
\hline TOTAL & 69 & 100 & 95 & 100 & 74 & 100 & 132 & 100 \\
\hline
\end{tabular}


TABLE A.11 Building E5633 Structural Survey Summary

\begin{tabular}{|c|c|c|c|c|c|c|c|c|}
\hline \multirow{2}{*}{ MATERIAL } & \multicolumn{7}{|c|}{ BY VOLUME } & \multicolumn{2}{c|}{ BY WEIGHT } \\
\cline { 2 - 8 } & \multicolumn{2}{|c|}{ In Situ } & \multicolumn{2}{|c|}{ As Rubble } & \multicolumn{2}{c|}{ Crushed } & \multicolumn{2}{c|}{} \\
\cline { 2 - 8 } & CY & $\%$ & CY & $\%$ & CY & $\%$ & Tons & $\%$ \\
\hline Clay Tile & 14 & 32 & 28 & 34 & 18 & 33 & 25 & 28 \\
Brick & 0 & 0 & 0 & 0 & 0 & 0 & 0 & 0 \\
Cinder Block & 0 & 0 & 0 & 0 & 0 & 0 & 0 & 0 \\
Plexiglas & 0 & 0 & 0 & 0 & 0 & 0 & 0 & 0 \\
Metal & 0 & 0 & 0 & 1 & 0 & 0 & 0 & 0 \\
Wood & 0 & 0 & 0 & 0 & 0 & 0 & 0 & 0 \\
Acid Brick & 0 & 0 & 0 & 0 & 0 & 0 & 0 & 0 \\
Tarmac & 0 & 0 & 0 & 0 & 0 & 0 & 0 & 0 \\
Structural Steel & 1 & 3 & 3 & 4 & 2 & 3 & 4 & 4 \\
Reinforced Concrete & 19 & 45 & 39 & 48 & 25 & 46 & 42 & 47 \\
Slab Concrete & 8 & 18 & 10 & 12 & 9 & 16 & 16 & 19 \\
Concrete Pavement & 0 & 0 & 0 & 0 & 0 & 0 & 0 & 0 \\
Asphalt Pavement & 0 & 0 & 0 & 0 & 0 & 0 & 0 & 0 \\
Miscellaneous & 1 & 1 & 1 & 1 & 1 & 1 & 1 & 1 \\
\hline TOTAL & 43 & 100 & 81 & 100 & 55 & 100 & 88 & 100 \\
\hline
\end{tabular}

TABLE A.12 Pilot Plant Grounds Structural Survey Summary

\begin{tabular}{|c|c|c|c|c|c|c|c|c|}
\hline \multirow{2}{*}{ MATERIAL } & \multicolumn{7}{|c|}{ BY VOLUME } & \multicolumn{2}{c|}{ BY WEIGHT } \\
\cline { 2 - 8 } & \multicolumn{2}{|c|}{ In Situ } & \multicolumn{2}{c|}{ As Rubble } & \multicolumn{2}{c|}{ Crushed } & \multicolumn{2}{c|}{} \\
\cline { 2 - 8 } & CY & $\%$ & CY & $\%$ & CY & $\%$ & Tons & $\%$ \\
\hline Clay Tile & 0 & 0 & 0 & 0 & 0 & 0 & 0 & 0 \\
Brick & 0 & 0 & 0 & 0 & 0 & 0 & 0 & 0 \\
Cinder Block & 0 & 0 & 0 & 0 & 0 & 0 & 0 & 0 \\
Plexiglas & 0 & 0 & 0 & 0 & 0 & 0 & 0 & 0 \\
Metal & 0 & 0 & 0 & 0 & 0 & 0 & 0 & 0 \\
Wood & 0 & 0 & 0 & 0 & 0 & 0 & 0 & 0 \\
Acid Brick & 0 & 0 & 0 & 0 & 0 & 0 & 0 & 0 \\
Tarmac & 0 & 0 & 0 & 0 & 0 & 0 & 0 & 0 \\
Structural Steel & 0 & 0 & 0 & 0 & 0 & 0 & 0 & 0 \\
Reinforced Concrete & 0 & 0 & 0 & 0 & 0 & 0 & 0 & 0 \\
Slab Concrete & 0 & 0 & 2 & 0 & 1 & 0 & 0 & 0 \\
Concrete Pavement & 387 & 76 & 774 & 76 & 503 & 76 & 836 & 77 \\
Asphalt Pavement & 111 & 22 & 222 & 22 & 144 & 22 & 217 & 20 \\
Miscellaneous & 10 & 2 & 21 & 2 & 13 & 2 & 28 & 3 \\
\hline TOTAL & 508 & 100 & 1,019 & 100 & 662 & 100 & 1,081 & 100 \\
\hline
\end{tabular}




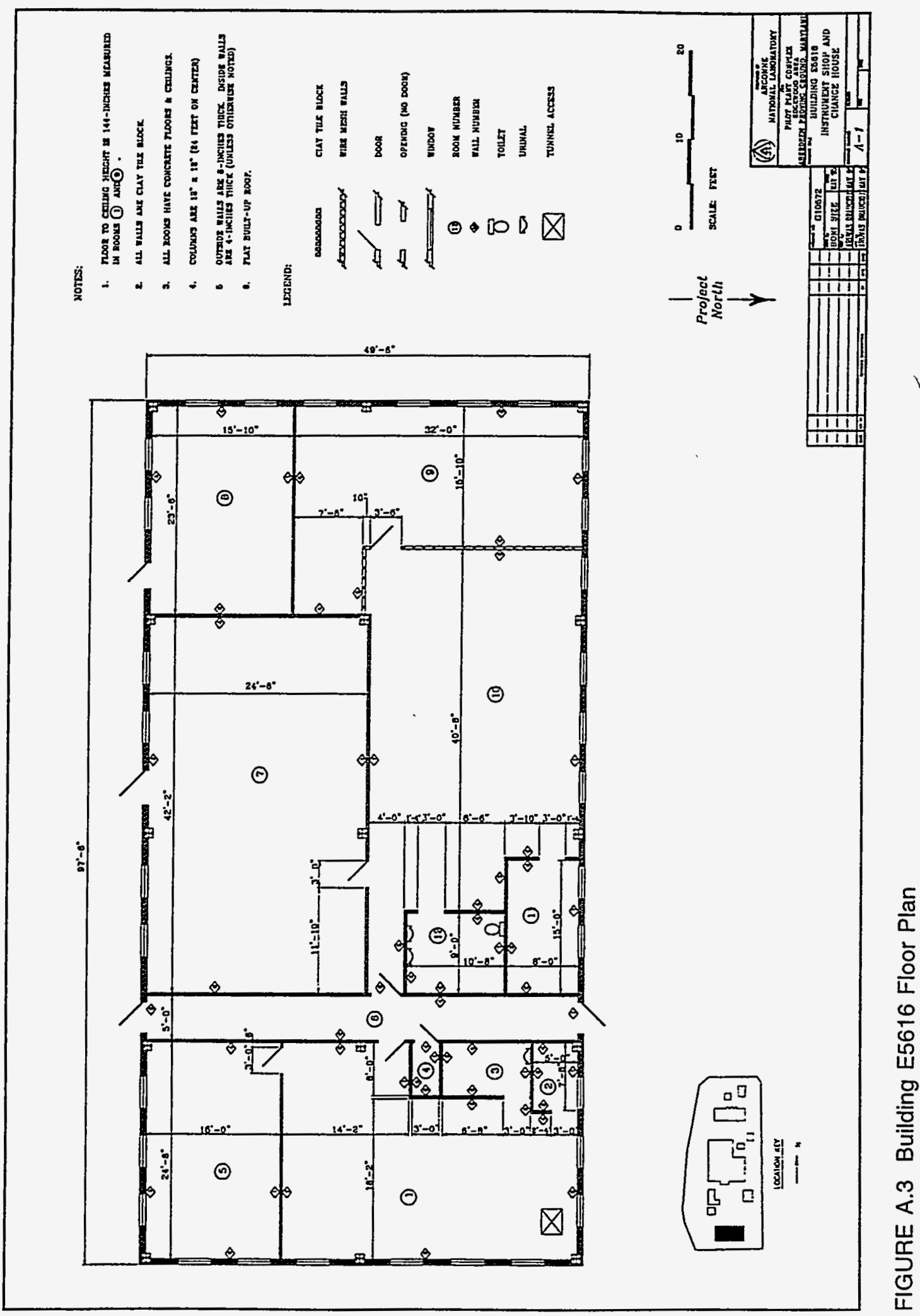




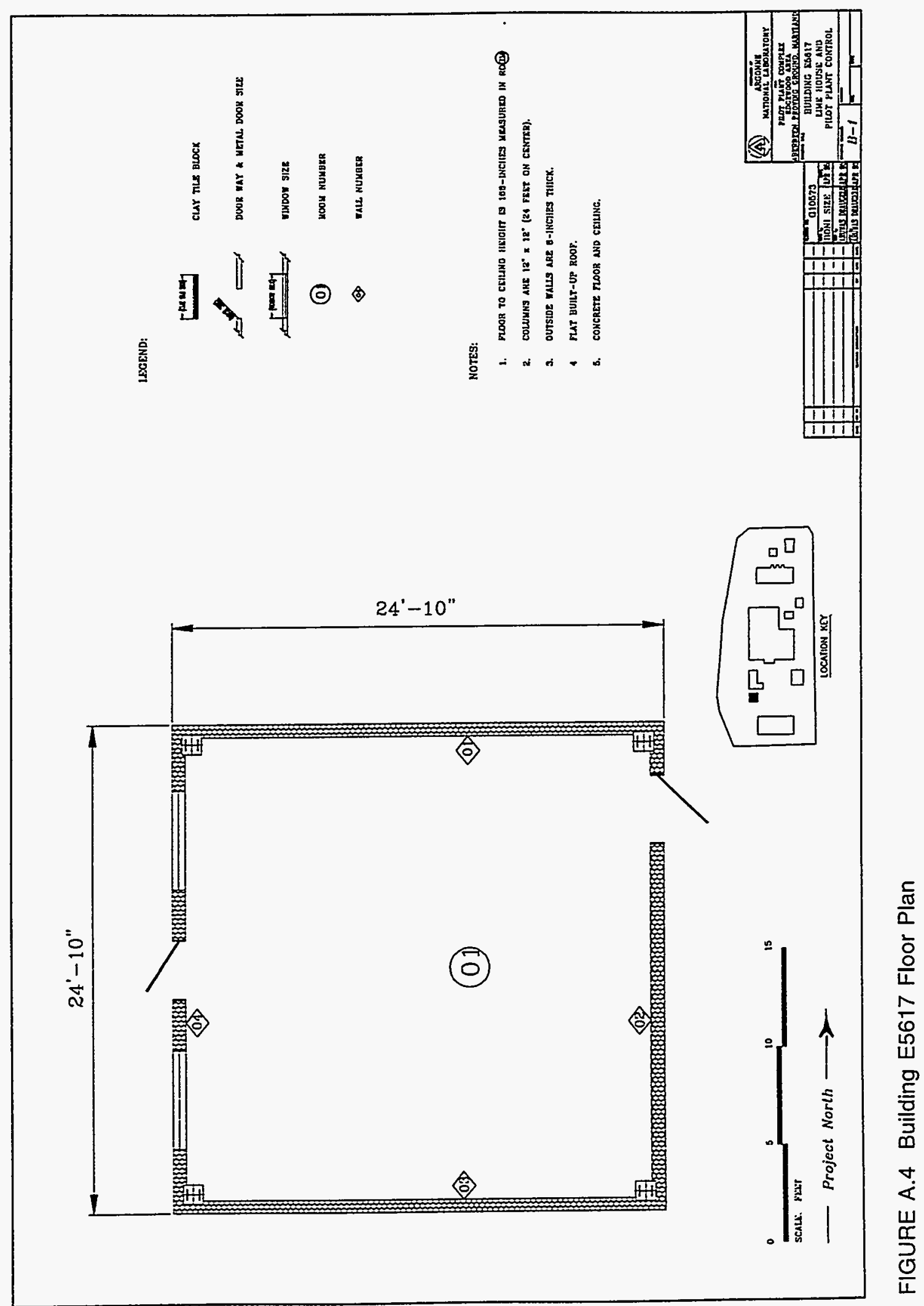




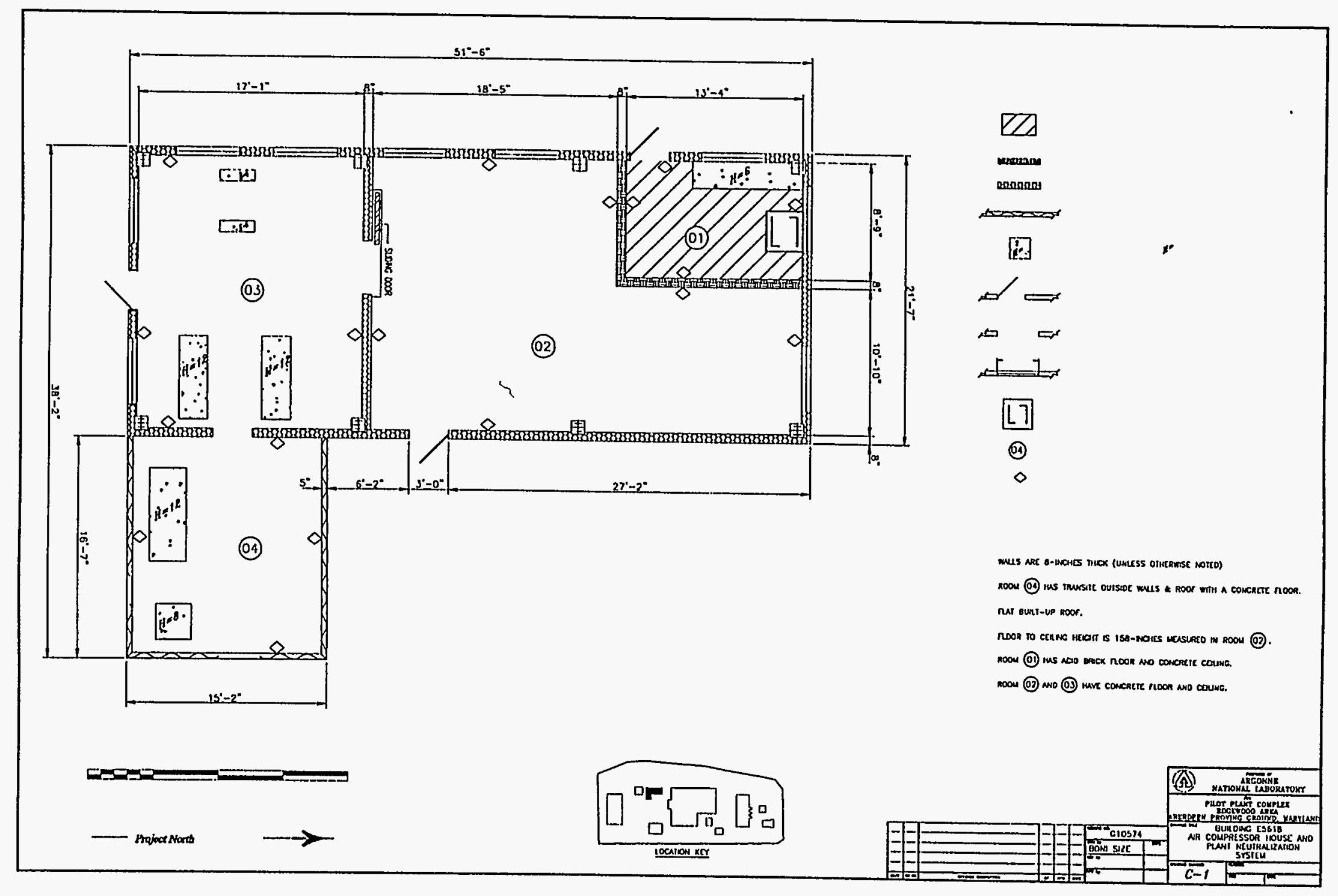

FIGURE A.5 Building E5618 Floor Plan 


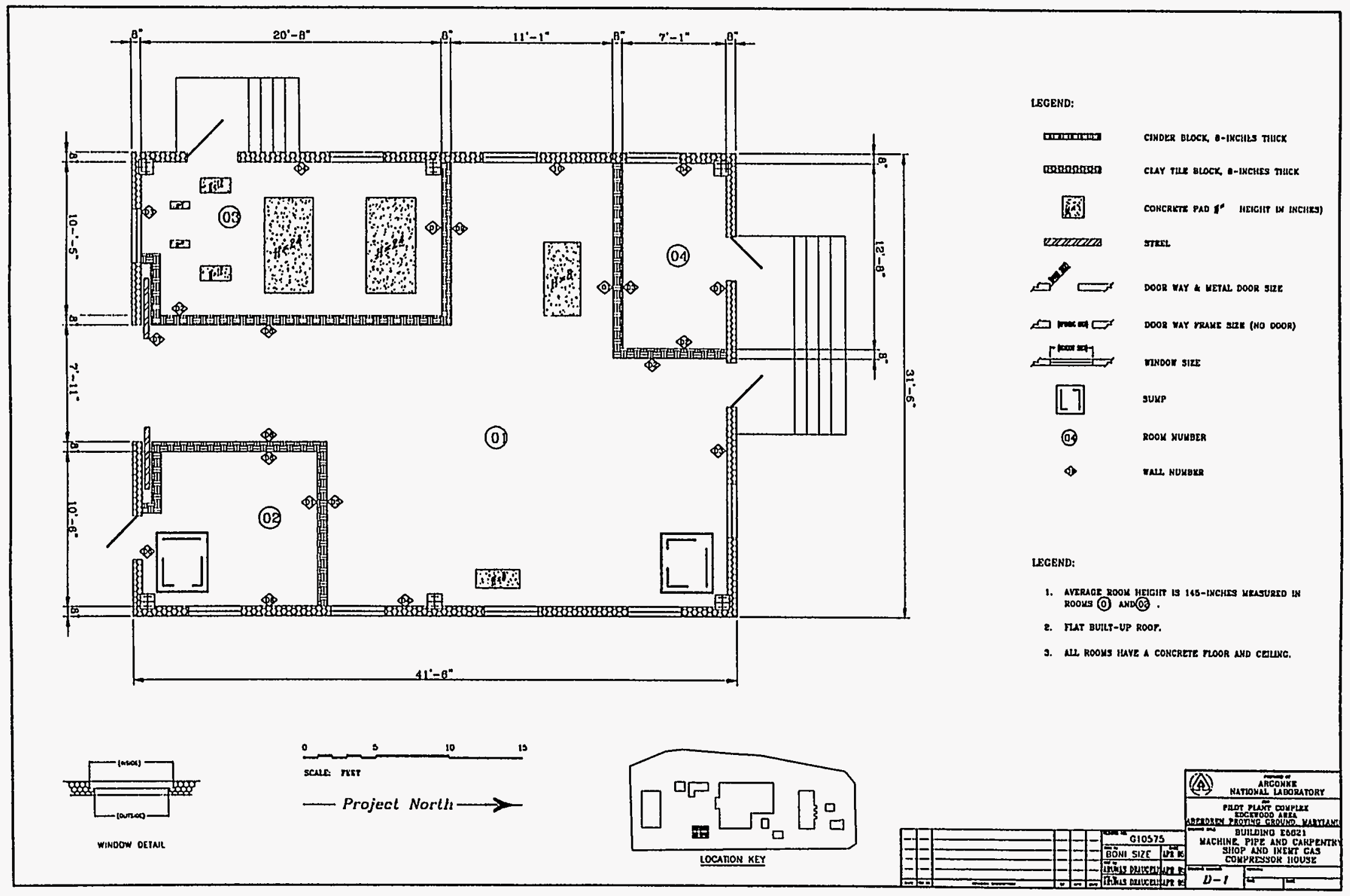

FIGURE A.6 Building E5621 Floor Plan 


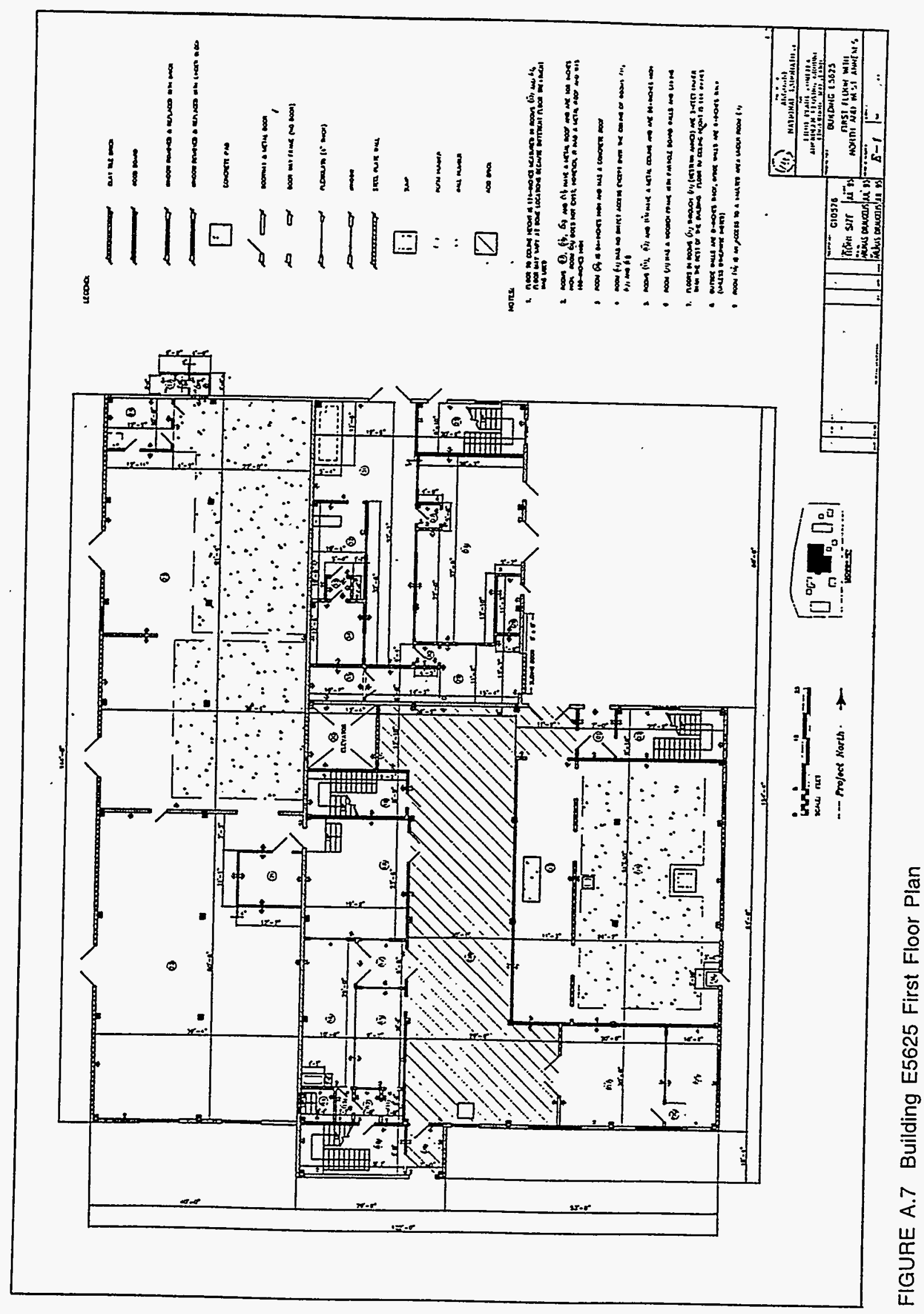




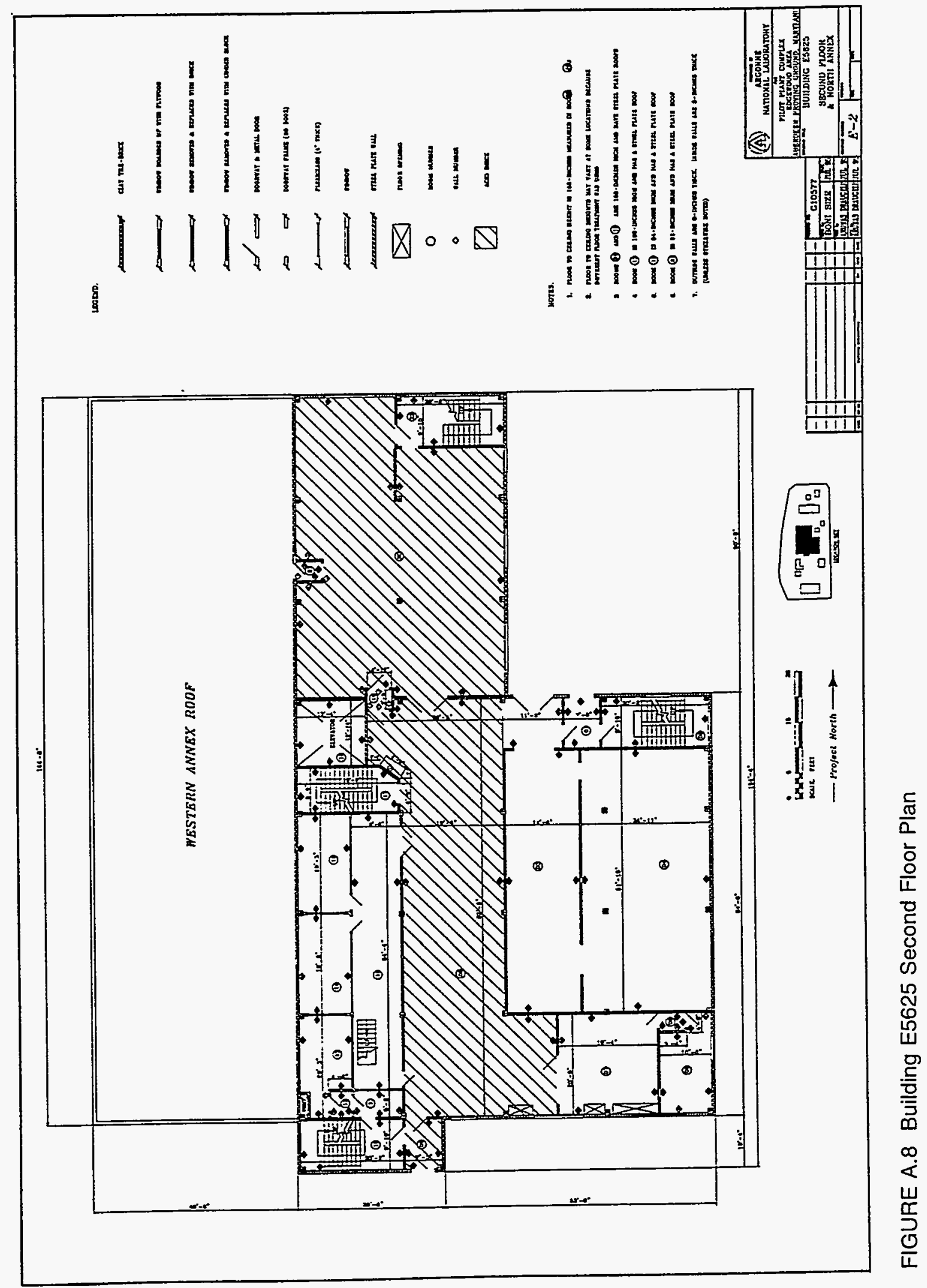




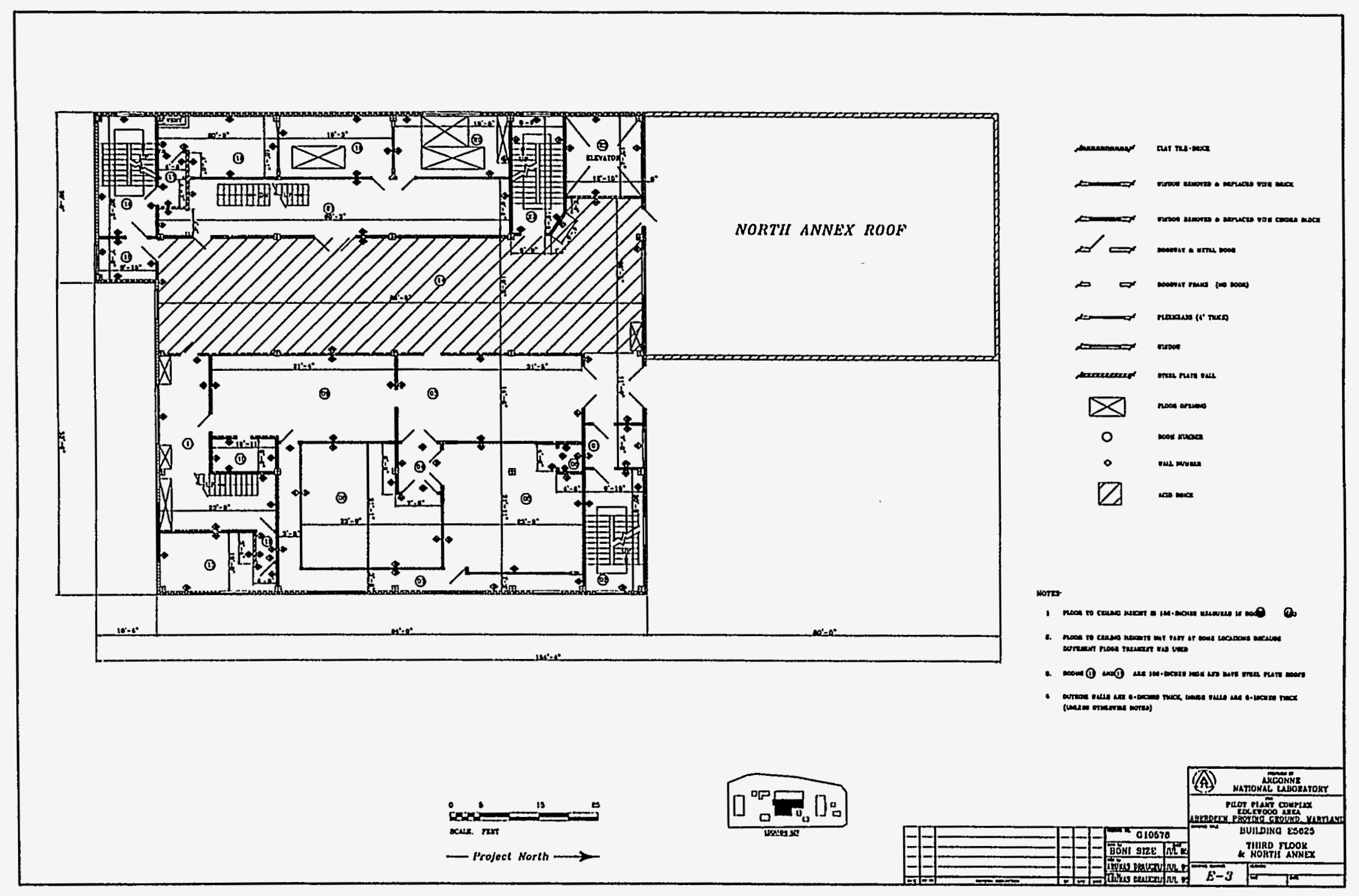

FIGURE A.9 Building E5625 Third Floor Plan 

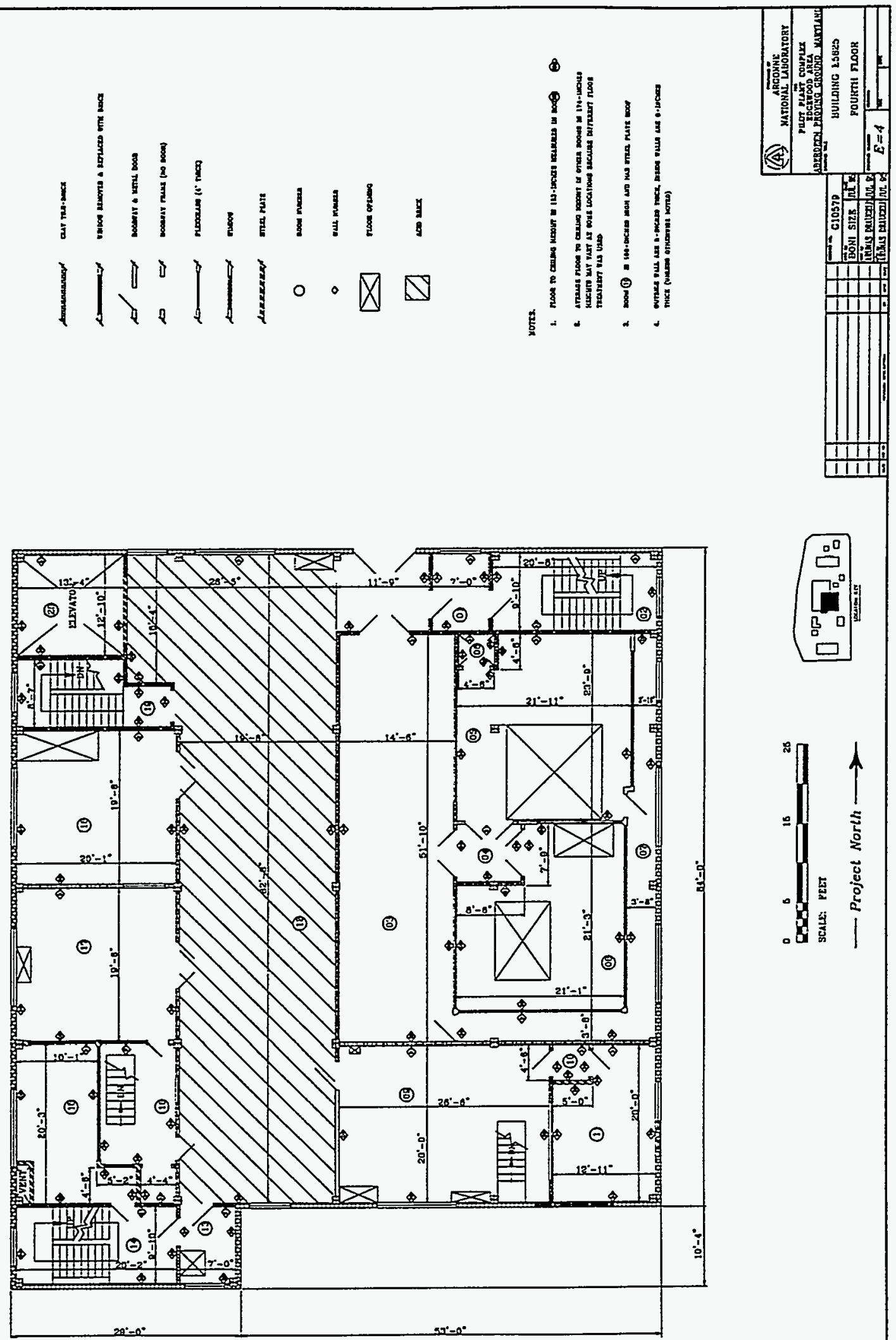

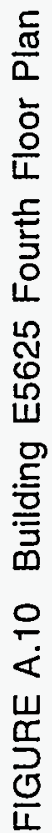




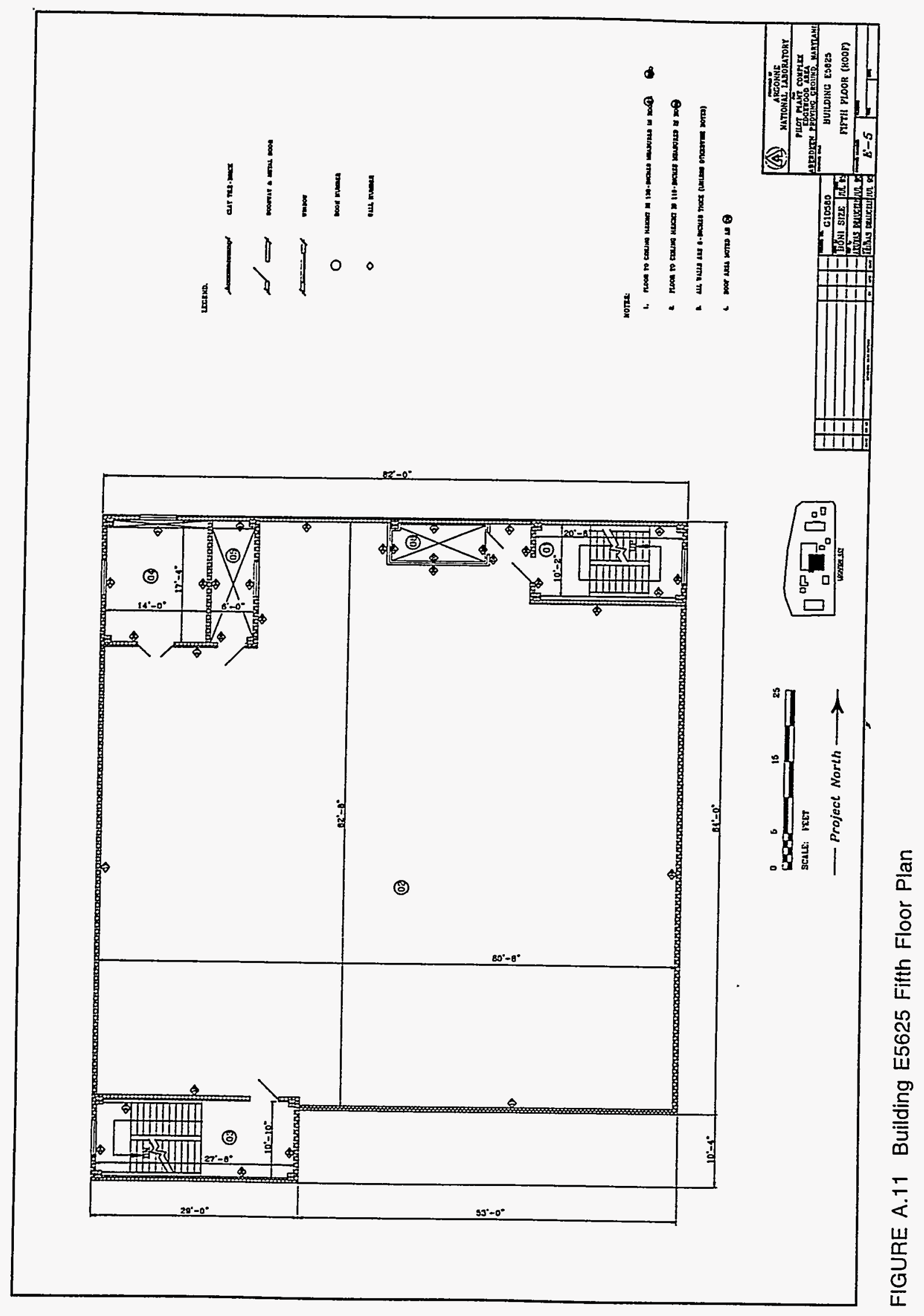




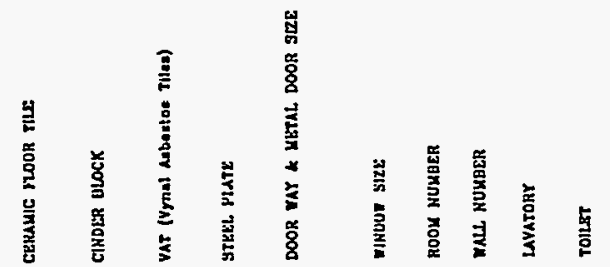

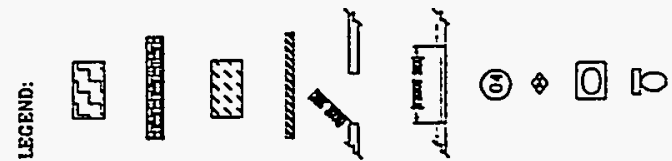
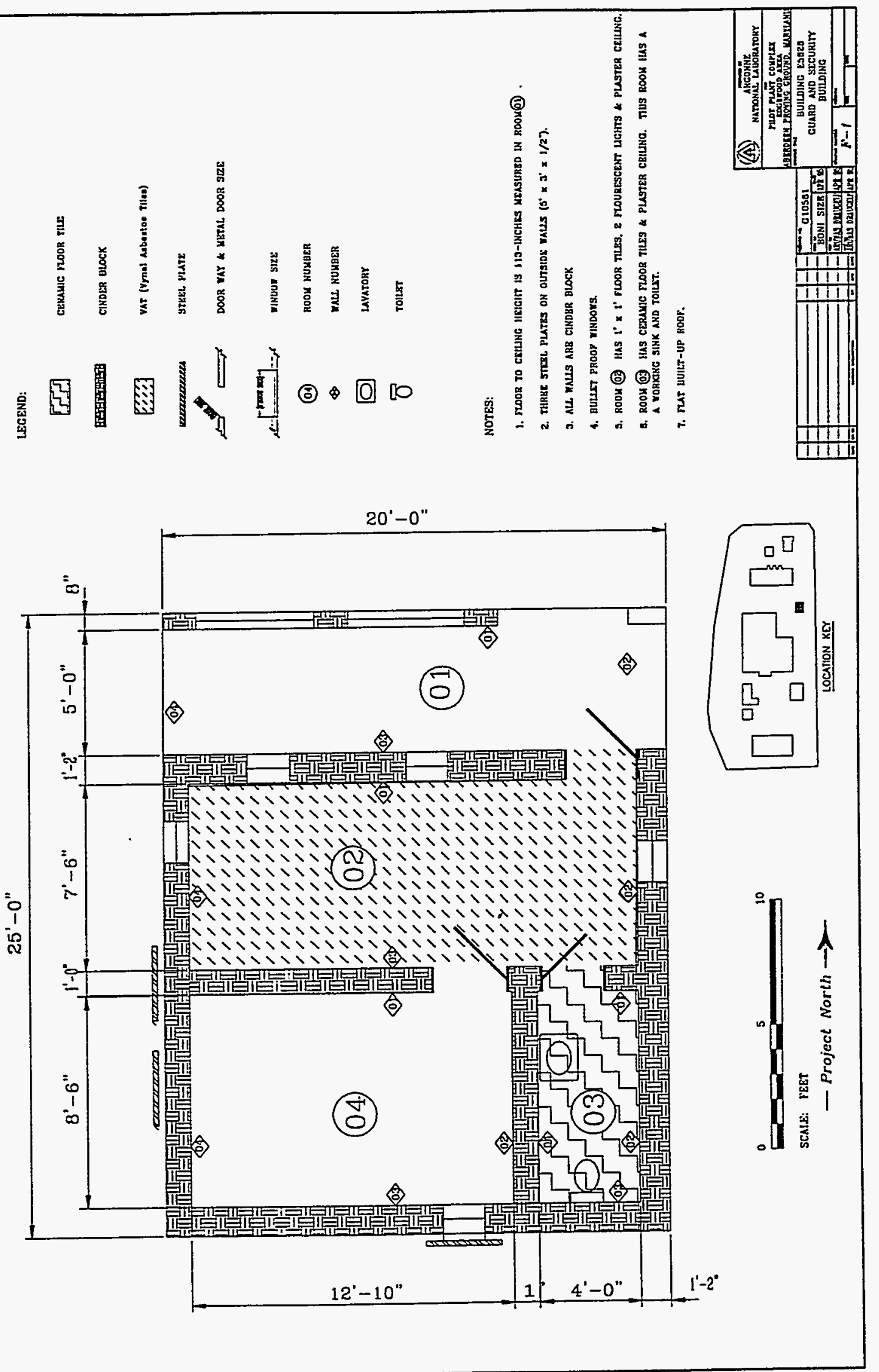

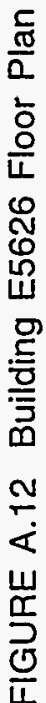




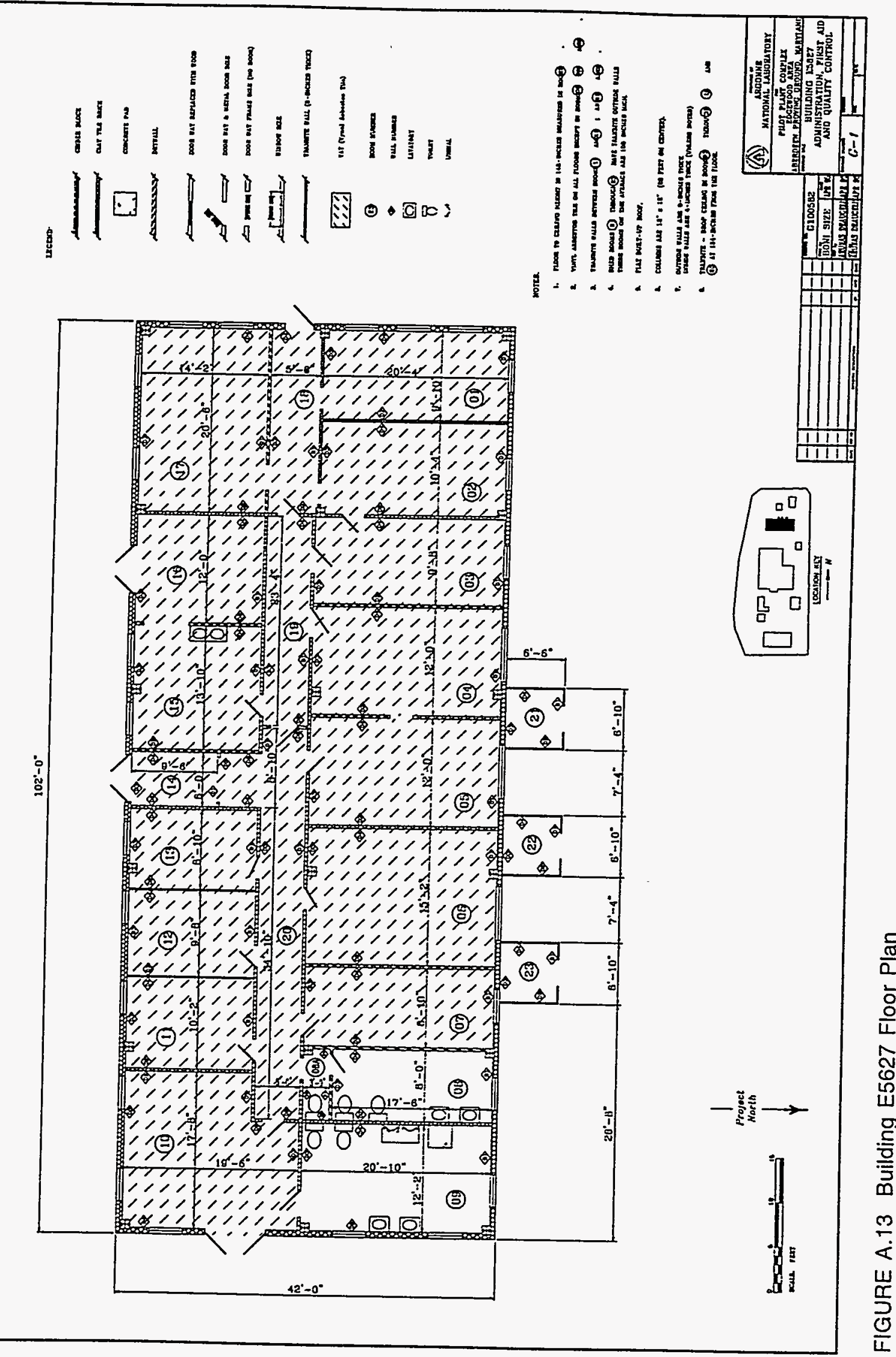




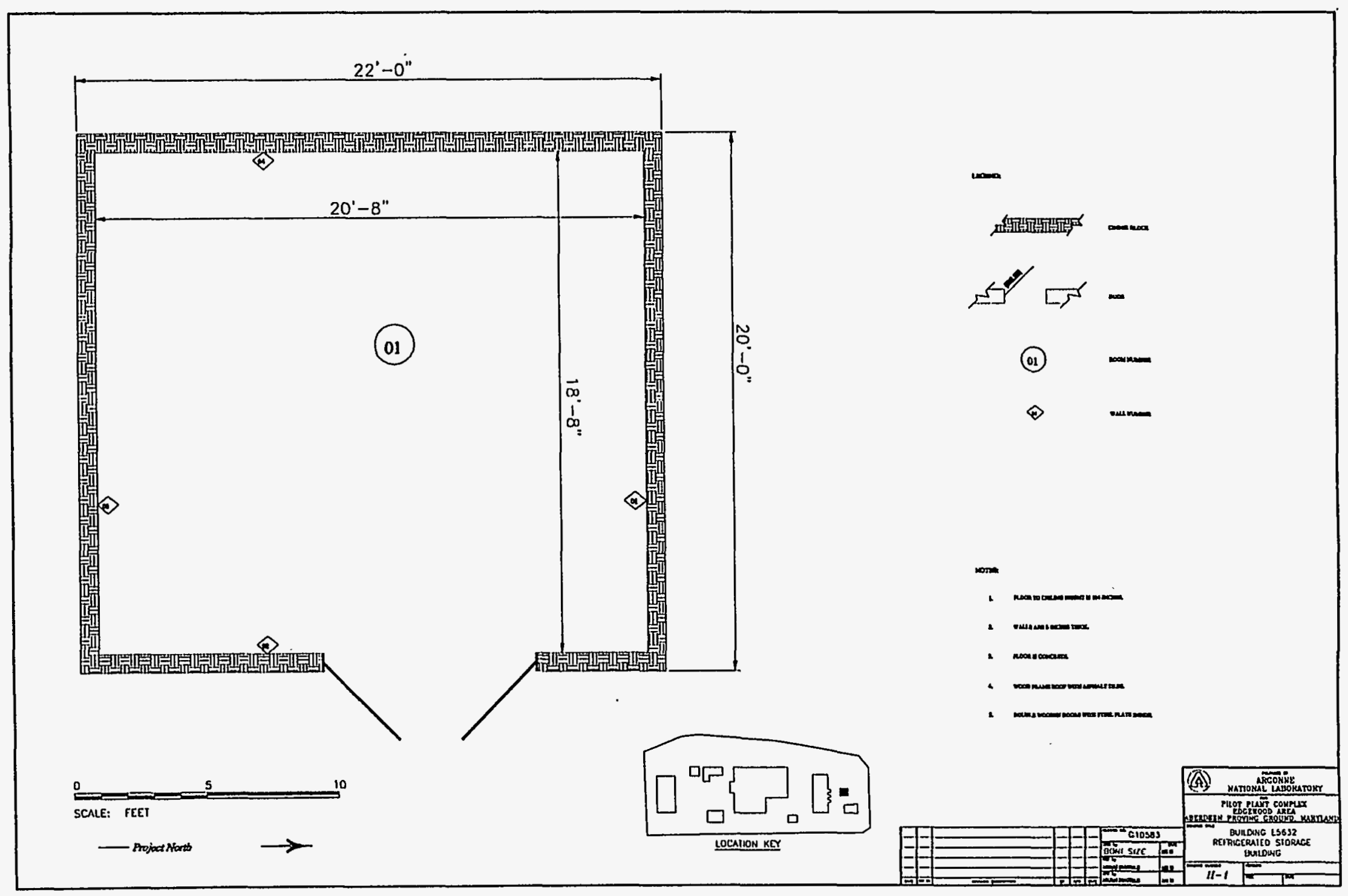

FIGURE A.14 Building E5632 Floor Plan 


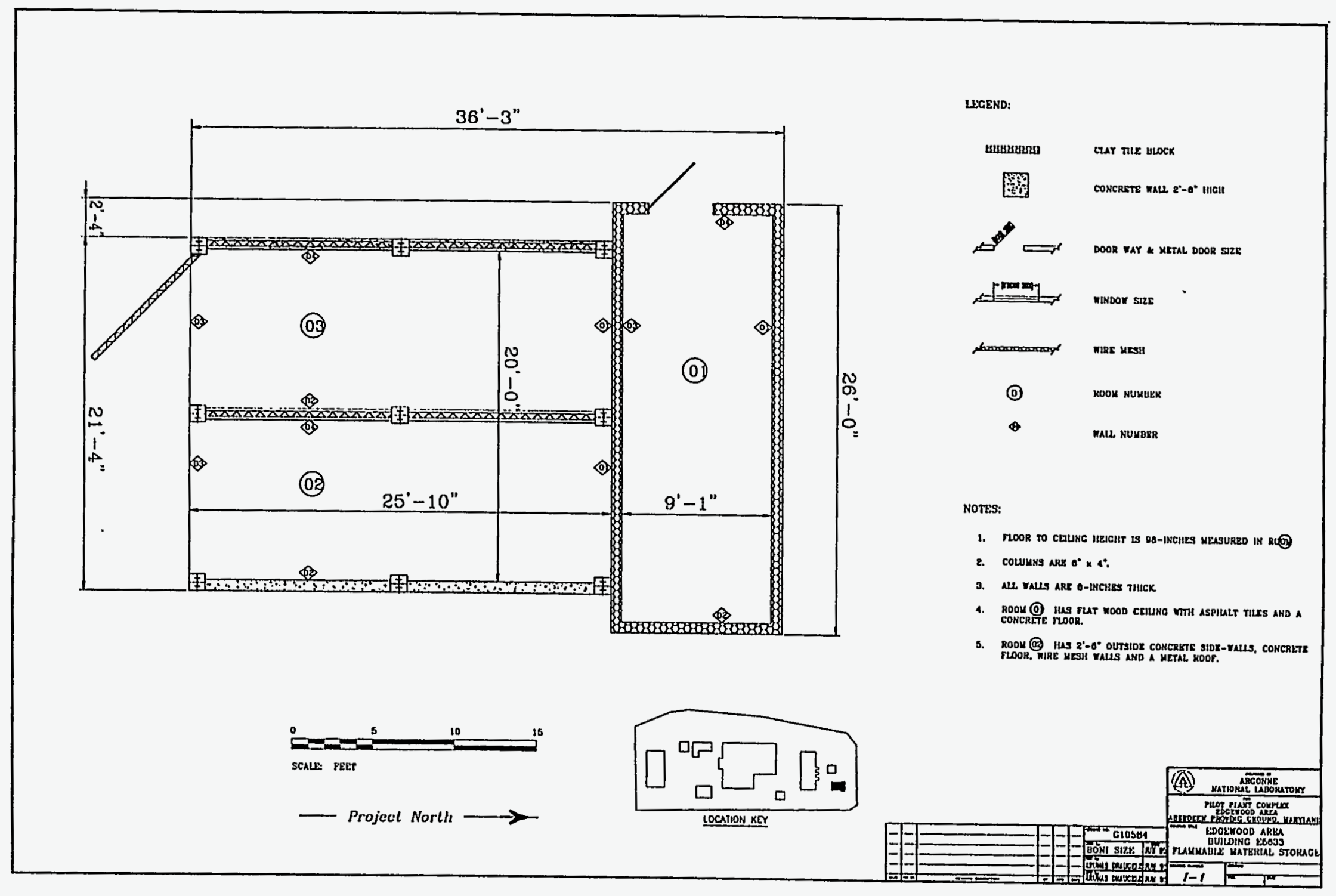

FIGURE A.15 Building E5633 Floor Plan 


\section{References}

Draugelis, A.K., et al., 1995a, Building E5616 Documentation and Quantification, Pilot Plant Complex, Aberdeen Proving Ground, Maryland, ANL/ESD/TM-123, Argonne National Laboratory, Argonne, Ill.

Draugelis, A.K., et al., 1995b, Building E5625 Documentation and Quantification, Pilot Plant Complex, Aberdeen Proving Ground, Maryland, ANL/ESD/TM-127, Argonne National Laboratory, Argonne, Ill.

Khanna, S., 1995, Draft Structural Integrity Evaluation and Demolition Quality Survey, Pilot Plant Complex, Aberdeen Proving Ground, Maryland, Tadjer, Cohen, Edelson and Associates, Inc., Consulting Structural Engineers, Silver Springs, Md.

Miller, G.A., et al., 1995, Building E5627 Documentation and Quantification, Pilot Plant Complex, Aberdeen Proving Ground, Maryland, ANL/ESD/TM-130, Argonne National Laboratory, Argonne, Ill.

Muir-Ploense, K., et al., 1995, Building E5626 Documentation and Quantification, Pilot Plant Complex, Aberdeen Proving Ground, Maryland, ANL/ESD/TM-131, Argonne National Laboratory, Argonne, Ill.

O'Reilly, D.P., et al., 1995a, Building E5618 Documentation and Quantification, Pilot Plant Complex, Aberdeen Proving Ground, Maryland, ANL/ESD/TM-125, Argonne National Laboratory, Argonne, IIl.

O'Reilly, D.P., et al., 1995b, Building E5621 Documentation and Quantification, Pilot Plant Complex, Aberdeen Proving Ground, Maryland, ANL/ESD/TM-126, Argonne National Laboratory, Argonne, Ill.

Smits, M.P., et al., 1995, Building E5617 Documentation and Quantification, Pilot Plant Complex, Aberdeen Proving Ground, Maryland, ANL/ESD/TM-124, Argonne National Laboratory, Argonne, Ill.

Zellmer, S.D., et al., 1995a, Building E5632 Documentation and Quantification, Pilot Plant Complex, Aberdeen Proving Ground, Maryland, ANL/ESD/TM-129, Argonne National Laboratory, Argonne, Ill.

Zellmer, S.D., et al., 1995b, Building E5633 Documentation and Quantification, Pilot Plant Complex, Aberdeen Proving Ground, Maryland, ANL/ESD/TM-128, Argonne National Laboratory, Argonne, Ill. 